\title{
História e comunicação na ordem internacional
}

\author{
Maximiliano Martin Vicente
}

VICENTE, MM. História e comunicação na ordem internacional [online]. São Paulo: Editora UNESP; São Paulo: Cultura Acadêmica, 2009. 214 p. ISBN 978-85-98605-96-8. Available from SciELO Books <http://books.scielo.org>.

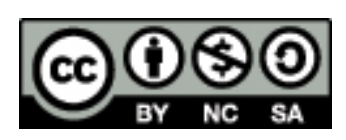

All the contents of this work, except where otherwise noted, is licensed under a Creative Commons Attribution-Non Commercial-ShareAlike 3.0 Unported.

Todo o conteúdo deste trabalho, exceto quando houver ressalva, é publicado sob a licença Creative Commons Atribuição Uso Não Comercial - Partilha nos Mesmos Termos 3.0 Não adaptada.

Todo el contenido de esta obra, excepto donde se indique lo contrario, está bajo licencia de la licencia Creative Commons Reconocimento-NoComercial-CompartirIgual 3.0 Unported. 


\section{HISTÓRIA E COMUNICAÇÃO NA NOVA ORDEM INTERNACIONAL}

MAXIMILIANO MARTIN VICENTE 


\section{História E COMUNICAÇÃO NA NOVA ORDEM INTERNACIONAL}



MAXIMILIANO MARTIN VICENTE

\author{
HistóRIa e \\ COMUNICAÇÃO NA \\ NOVA ORDEM \\ INTERNACIONAL
}

CULTURA

$\frac{\text { ACADÊMICA }}{\text { Editora }}$ 
(C) 2009 Editora UNESP

\section{Cultura Acadêmica}

Praça da Sé, 108

01001-900 - São Paulo - SP

Tel.: (0xx11) 3242-7171

Fax: (0xx11) 3242-7172

www.editoraunesp.com.br

feu@editora.unesp.br

CIP - Brasil. Catalogação na fonte

Sindicato Nacional dos Editores de Livros, RJ

V681h

Vicente, Maximiliano Martin, 1956-

História e comunicação na ordem internacional / Maximiliano Martin

Vicente. - São Paulo : Cultura Acadêmica, 2009.

Inclui bibliografia

ISBN 978-85-98605-96-8

1. Le Monde Diplomatique. 2. História - Aspectos sociais. 3. Jornalismo - Aspectos sociais. 4. Imprensa e política. 5. Relações internacionais. I. Título.

09-6058.

CDD: 302.2

CDU: 316.77

Este livro é publicado pelo Programa de Publicações Digitais da Pró-Reitoria de Pós-Graduação da Universidade Estadual Paulista "Júlio de Mesquita Filho" (UNESP)

Editora afiliada:

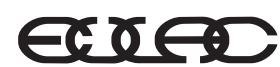

Asociación de Editoriales Universitarias de América Latina y el Caribe

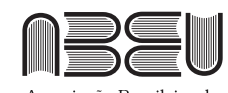

Associação Brasileira de Editoras Universitárias 


\section{SUMÁRIO}

Apresentação 7

PARTE I - História e comunicação 13

1 História da comunicação social: um campo em construção 19

2 O acontecimento histórico e o acontecimento comunicacional 43

3 Correntes históricas contemporâneas 67

4 Comunicação e história: aproximações 93

PARTE II - Comunicação e contemporaneidade 117

5 A crise do Estado de bem-estar social e a globalização: um balanço 123

6 A concentração midiática em tempos de neoliberalismo 147

7 Estudo de caso: o 11 de setembro de 2001 na Veja e no Le Monde Diplomatique 167

Conclusão 193

Referências bibliográficas 199

Anexos 205 



\section{Apresentação}

Este livro resgata algumas das discussões teóricas que estiveram presentes nas nossas atividades de pesquisa dos últimos anos, notadamente aquelas relacionadas às atividades docentes na UNESP, no campus de Bauru. Ingressei na UNESP, no campus de Marília, no curso de Ciências Sociais. Nesse campus, elaborei minha dissertação de mestrado e boa parte da tese de doutorado, razão pela qual refletem uma problemática típica da área de Ciências Sociais. A análise do Estado autoritário implementado por Vargas, abordado com base na teoria de Juan Linz, completava um percurso iniciado no mestrado quando estudamos os partidos políticos em Bauru, na década de 1930.

A vinda para Bauru não significou apenas sair da área de Ciências Sociais para entrar na de Ciências Sociais Aplicadas, concretamente nos cursos de Jornalismo, Rádio e Televisão, e Relações Públicas. $\mathrm{Na}$ verdade, tal mudança constituiu um recomeço nas leituras e um adentrar, sem rumo claramente definido, no mundo da comunicação. É verdade que, nas pesquisas feitas anteriormente, os jornais tiveram um tratamento privilegiado. Mas uma coisa é estudar um produto pronto, como pode ser um exemplar de jornal, e outra é apreender a lógica de seu funcionamento e adentrar nas suas nuanças específicas. Entender o processo de elaboração de um jornal, aquele que lemos todos os dias, exigiu estudos e abordagens desconhecidas até então. 
Nessa caminhada, o primeiro movimento, quase que um movimento de defesa, consistiu em recorrer aos historiadores e às teorias da história que considerava próximas do jornalismo. Sabíamos da relação da história com o progresso das comunicações. Algumas passagens curiosas - quase anedóticas - vinham à nossa lembrança, mas muito vagamente. Prefiro enfrentar mil baionetas a três jornais, parece ter sido uma das frases de efeito de Napoleão. Thomas Jefferson iniciou seu mandato assegurando categoricamente que, sem imprensa, não existia democracia. No entanto, à medida que a imprensa atacava sua gestão, sugeria, tão ardorosamente quanto tinha assumido a defesa da liberdade de expressão, que não ler os jornais significava estar mais informado do que ler notícias mentirosas nas páginas de qualquer libelo. A democracia tem seus percursos nem sempre condizentes com determinados interesses. Mas tudo isso não permitia nada mais do que comprovar a relevância do jornalismo, motivo pelo qual decidimos estudar, mais detidamente, o significado social desse veículo de comunicação.

Com o objeto de estudo delimitado, partimos para a busca de uma teoria social dos meios. As referências sobre essa teoria escasseiam notadamente ao tomar como base a América Latina. $\mathrm{O}$ mesmo não pode ser dito do jornalismo, motivo pelo qual decidimos optar por privilegiar esse campo da comunicação social. Assim, não ignoramos as leituras e a trajetória desenvolvidas no campus de Marília. Havia a possibilidade de ligar as duas áreas de conhecimento sem esquecer as particularidades e nuanças de cada uma delas.

O resultado dessas leituras é apresentado na primeira parte do livro, que engloba os quatro capítulos iniciais. Neles, detalhamos os pontos de junção de história e do jornalismo no intuito de realizar uma aproximação dessas duas áreas do conhecimento. Não ignoramos os riscos envolvidos nessa tarefa, motivo pelo qual buscamos autores que entendem a comunicação social, e o jornalismo em particular, como instrumentos de influência social, notadamente nos tempos mais recentes, conhecidos como tempos midiatizados, ou representados pelas informações emanadas da mídia. Apesar de o jornalismo ter um lado voltado para o entretenimento, decidimos 
abandonar essa vertente, assim como não incluímos nas nossas pesquisas a comunicação não verbal, temática essa cada vez mais atuante na área da comunicação.

Alguns autores, detalhados no transcorrer do livro, constituem a base na qual fundamentamos nossas interpretações. Coincidentemente, todos destacam o papel social da comunicação e adentram nos estudos das possibilidades de como se materializa sua influência no cotidiano das pessoas. Justamente, esse tema passou a ser abordado mais detidamente por meio do estudo do Le Monde Diplomatique, um veículo de circulação internacional e conhecido pelo seu teor crítico e independente diante do universo da comunicação eminentemente mais comercial, interessada no lucro e não na informação.

Para consolidar os procedimentos das análises desse jornal, foi necessário levar em consideração os resultados das abordagens da história e da comunicação social. Ficou claro, nessa trajetória, que o receptor ainda mantém traços de autonomia diante dos meios de comunicação. Por sua vez, as notícias divulgadas, mantidas e alimentadas pelos meios fazem parte do cotidiano da maioria das pessoas da sociedade, alimentando seu imaginário e sua representação simbólica do contexto em que atuam. Assim, chegamos à convicção da importância do conteúdo divulgado nos meios e, mais especificamente, nos jornais, pois neles se estabelece toda uma sequência para que a matéria seja divulgada com uma determinada informação. Ela pode despertar a preocupação social, a alienação ou a manipulação.

Desse modo, iniciamos a segunda parte do texto, agrupando os capítulos 5, 6 e 7, na qual tecemos considerações mais concretas no estudo do jornal selecionado: o Le Monde Diplomatique. O procedimento definido nessa segunda parte procura exercitar, na prática, o percurso estabelecido na primeira parte do livro. Dessa forma, inicia-se o capítulo quinto realizando a contextualização na qual se encontram o pesquisador e o objeto pesquisado. Ocorre que na contextualização se inserem crenças, opções, ideologias e demais valores, motivos que acreditamos suficientes para nos levar ao ponto central do estudo de caso apresentado no capítulo sétimo. Efetivamente, além da contextualização, torna-se vital apresentar a opção assumida 
pelo autor. No nosso caso, deixamos claro que entendemos a comunicação e a história como duas áreas voltadas para a transformação social e como ferramentas de desconstrução de discursos, ideias e versões. Por essa razão os capítulos quinto e sexto, dessa segunda parte, se preocupam em identificar os componentes macro, presentes no momento da elaboração do texto. Ambos teriam a finalidade de contextualizar o neoliberalismo e seu impacto na comunicação.

Nesse sentido, nos três capítulos apresentados na segunda parte do livro, existe uma coerência na abordagem do fato social, tal como apresentado pelos meios de comunicação, e na maneira como se elaboram visões simplistas e manipuladoras por estarem alinhadas com interesses meramente comerciais. A comunicação hoje, ou melhor, as empresas voltadas para o setor comunicacional formam grandes conglomerados que visam ao lucro e não a um despertar de consciência crítica ou de cidadania. Assim, as abordagens devem primar pela decodificação de conteúdos e demais valores contidos nas notícias, principalmente por saber que as versões apresentadas serão lembradas pelos leitores na hora de formar e formular suas opiniões.

Para exemplificar a trajetória anunciada, estuda-se um caso concreto relacionado com um acontecimento marcante: o ataque às torres gêmeas em 11 de setembro de 2001. O episódio repercutiu de tal forma que se considera vital para iniciar um século XXI da maneira mais inusitada possível: os Estados Unidos sendo atacados no seu território em pleno desenvolvimento dos escudos antimísseis. Abordamos o trágico evento de maneira comparativa no intuito de aferir o significado atribuído por dois meios de comunicação com linhas editoriais opostas (Veja e Le Monde Diplomatique). Dessa maneira, tecemos considerações, procurando compreender os mecanismos seguidos por cada meio na apresentação do evento para seus respectivos leitores. O pano de fundo seguido consiste na aplicação dos componentes teóricos, apontados na primeira parte, e na contextualização do mundo em que vivemos, realizada na segunda.

Os resultados, embora já esperados, em função das divergências dos veículos selecionados, se mostram bastante interessantes por comprovar que é possível operar na comunicação com as estratégias 
da história. A atualidade pode adquirir um significado mais profundo e complexo quando se atenta para alguns princípios como: abertura para as partes envolvidas, cuidado com os termos usados, manifestação de ideias preconcebidas, não manipular a história, entre outros.

Um caminho em construção? Pergunta importante a que se tentará responder no transcorrer do texto, se não na sua totalidade, pelo menos assinalando alguns traçados que tornarão o caminho mais viável e seguro. Aparar divergências, aprofundar discussões, abordar mais estudos de caso para ilustrar os caminhos seguidos são pontos importantes nessa tentativa de aproximação. Não se trata apenas de um exercício de interdisciplinaridade, o que também é, mas sim de aprofundar um projeto que viabilize a proposta de realizar leituras englobando a história e a comunicação social. Afinal, acreditamos que todos aprendem com esse contato. Essas são algumas das ideias norteadoras do presente livro. 

PARTE I

HISTÓRIA E COMUNICAÇÃO 

Uma relação de afinidade e de conflito. Talvez essa seja a melhor fórmula para definir a conexão entre a história e a comunicação. A similaridade decorre da proximidade e da convergência, tanto na hora de enfrentar seus dilemas quanto na de procurar solucioná-los. Ambas convivem com embates internos semelhantes, nem sempre bem resolvidos. Burke \& Briggs (2002, p.12), abordando essa afinidade, afirmam que

[...] seja qual for o ponto de partida, torna-se necessário que aqueles que se preocupam com a história e a comunicação e a cultura tema que cada dia ganha mais adeptos - levem com mais seriedade e atenção a história, e os historiadores - seja qual for o tema ou período que estudem - considerem de maneira mais cuidadosa em seus estudos a comunicação (incluindo a teoria da comunicação).

Aceitar esse desafio implica, inicialmente, identificar os assuntos mais polêmicos envolvidos nessa discussão, na tentativa de compreender seus pontos de atrito e apontar possíveis saídas. Numa perspectiva ampla, as divergências perdem sentido, resultando, na maioria das ocasiões, em questões alimentadas por posicionamentos teóricos e pessoais daqueles que estudam tanto a história quanto 
a comunicação, mas nada que crie obstáculos impossíveis de serem solucionados. Tal situação impede, na prática, a identificação das discordâncias reais geradoras dessa desconfiança mútua, assim como dificulta a conciliação de interesses e a procura por fatores convergentes.

Os historiadores alimentam a ideia da superficialidade realizada pelos comunicólogos nas suas análises. Eles apresentariam os fatos de maneira rápida, descontextualizada, sem reflexão ou criticidade. Já os comunicólogos se sentem incomodados com a falta de atualização e preocupação dos historiadores com os episódios recentes. O passado seria o campo preferencial no qual a história procura encontrar seu sentido e fundamentar suas afirmações. Assim, excluindo o presente, a história teria pouca utilidade para a comunicação mais voltada para a atualidade.

De imediato surge uma questão. Trata-se, apenas, de diferenças cronológicas, de concepções teóricas ou de desconhecimento mútuo? Responder a essa indagação remete à forma como as duas áreas procedem na elaboração dos seus estudos. Para isso, servimo-nos de algumas ideias de Bourdieu (1978), notadamente a que diz respeito ao habitus e à maneira como isso resulta em organizações sociais. Para Bourdieu, os atores sociais se encontram inseridos num determinado contexto social que, de certa maneira, determina seu comportamento por estarem expostos às influências culturais, sociais, econômicas, políticas, artísticas etc. O campo social emerge como palco das disputas no qual cada grupo tenta fazer valer seus próprios valores. Assim, a ideia de campo social implica a aceitação de articulação dos sujeitos na formação de estruturas. Partindo dessas observações e aceitando que tanto a história quanto a comunicação coincidem na sua finalidade, ou seja, na compreensão e na decodificação da formação da sociabilidade, urge identificar quais são os procedimentos usados na construção de narrativas explicativas dos fatos sociais.

Para atingir esse objetivo, parece-nos importante estruturar este livro de tal forma que consigamos identificar, num primeiro momento, as nuanças de cada área do conhecimento, no intuito de criar um diálogo tal como proposto por Burke \& Briggs (2002). 
Quatro capítulos compõem a estrutura desta primeira parte do texto. No primeiro, mostraremos as dificuldades para se conceituar a história da comunicação social, além de realizar uma analogia entre a história e a comunicação, procurando privilegiar suas aproximações e respeitar suas diferenças. As peculiaridades da história da comunicação social no continente latino-americano se incluem no capítulo. No segundo, adentramos no que parece ser o ponto ideal: compreender as especificidades da história e da comunicação na abordagem dos fatos. Observar e apontar suas especificidades nos permite conhecer melhor o procedimento de cada área na hora de elaborar suas análises. No terceiro, realiza-se uma apresentação de correntes históricas preocupadas com a contemporaneidade. A história do tempo presente e seus desdobramentos emergem como objeto de nossas reflexões. Nele, veremos como se originou a ideia de história do presente e dos seus desdobramentos como a história imediata e a história a debate. Veremos que todas coincidem no estudo de temas recentes, além de propor uma metodologia para sua abordagem. No quarto e último capítulo desta primeira parte, procura-se estabelecer parâmetros de aproximação entre a história e a comunicação para aferir as possibilidades de sua aplicação num estudo de caso concreto. 



\section{1 \\ HISTÓRIA DA COMUNICAÇÃO SOCIAL: UM CAMPO EM CONSTRUÇÃO}

"[...] tudo que os homens fazem, sabem ou experimentam só tem sentido na medida em que pode ser discutido." (Hannah Arendt)

Sem pretender esgotar o tema, nas páginas seguintes realizaremos uma tentativa de mostrar o estado da questão na construção da história da comunicação social. Um primeiro levantamento bibliográfico, destinado a identificar obras relacionadas ao assunto, comprova o quanto esse tema passou despercebido na academia. Proliferam os autores especializados na história de cada meio de comunicação (jornal, rádio, televisão, cinema e, ultimamente, internet), mas poucos enfrentaram o desafio de construir uma história da comunicação social. Razões para justificar essa lacuna não faltam. Vão desde o fato de se tratar de uma ciência jovem, portanto em construção, até a ausência de uma definição clara em relação ao objeto, fontes e métodos próprios dessa área de conhecimento. Afinal, o jornalismo e o cinema, por exemplo, podem ser inseridos num mesmo procedimento metodológico?

A história da comunicação social nasce e se consolida entre o final da década de 1940 e meados da década de 1970. Nesse início, predominavam os temas relacionados à contemporaneidade, embo- 
ra o papel da comunicação na Antiguidade clássica também tenha merecido a atenção dos estudiosos da comunicação social (Diaz \& Alffond, 2001). O jornalismo passou a ser o alvo principal de estudo pela abundância de fontes disponíveis e pela relevância adquirida na sociedade.

Duas referências metodológicas predominavam naquele momento, seguindo campos de investigações claramente diferenciados. Uma consolidada nos Estados Unidos e na Europa desde o final do século XIX, em pleno auge do positivismo histórico, voltada para o estudo diacrônico da imprensa e, com menor frequência, para os assuntos do rádio e cinema. A outra, nascida da crítica ao modelo positivista, dominante, também, em vários países do mundo ocidental, notadamente nos Estados Unidos, atuava no sentido de avaliar os impactos do jornalismo nas audiências, permitindo o surgimento de reflexões teóricas mais complexas do que as propostas pelo positivismo (Mattelart, 1995; Wolf, 1987). O desdobramento político da Segunda Guerra Mundial interferiu na evolução dessa segunda teoria, iniciando-se, dessa forma, uma abertura à qual se incorporariam aportes teóricos e metodológicos provenientes de outras ciências da área de humanas. Fruto dessa movimentação, três grandes matrizes metodológicas com suas preocupações e abordagens predominariam nas relações entre a comunicação e a sociedade: o marxismo, o funcionalismo e os autores dos Annales.

Marx e Engels não trataram especificamente do tema da comunicação, mas não se pode ignorar a interferência do materialismo dialético na construção da história da comunicação social. ${ }^{1} \mathrm{O}$ eixo central do marxismo, expresso na obra Contribuição à crítica da economia política, implicava a aceitação de alguns princípios básicos como a existência do conflito na mudança social. Tal conflito ocorreria

1 Marx, como jornalista, teve uma vasta produção copilada, quase na sua totalidade, em duas obras. A primeira, reunindo os artigos publicados no periódico Nova Gazeta Renana, produzidos em 1848, no auge do processo revolucionário que agitava a Europa, é A burguesia e a contrarrevolução. As publicações seguintes, reunidas sob o título de Revolução e contrarrevolução, foram produzidas três anos mais tarde, para o jornal norte-americano A Tribuna de Nova Iorque. 
no embate entre as forças sociais de produção existentes e as emergentes. Ainda nessa obra, Marx destaca que o modo de produção determina o modelo de relações sociais e acentua a existência de uma superestrutura política, jurídica e ideológica como instrumentos perpetuadores das relações de dominação de classe. Nesse campo pode ser inserido o papel dos meios de comunicação por defenderem conceitos intangíveis, mas presentes, na formulação e expressão de valores determinantes, na consolidação de ideias e pensamentos e outras práticas, na maioria das ocasiões, conservadores e a serviço da classe dirigente.

Para que aconteçam câmbios, segundo a lógica marxista, um dos elementos centrais diz respeito à visão crítica da realidade, capaz de evitar a alienação das pessoas em relação ao momento e à conjuntura nos quais se encontram inseridas. Diminuir a influência desses mecanismos conservadores passa a ser uma das frentes de ação dos agentes da revolução. Os meios de comunicação, nesse contexto, poderiam ser instrumentos a favor da mudança, na medida em que denunciassem, com seus conteúdos, a maneira como a burguesia perpetua seu poder e formas de ascendência. ${ }^{2}$ Metodologicamente, o pensamento marxista contribuiu para formular uma teoria das ideologias que estabelecia uma relação direta entre estruturas sociais, formações ideológicas, produtos discursivos e meios de comunicação. A função ideológica e comunicativa carregaria todas as contradições latentes da realidade perpetuadas a partir de uma ótica de classe, ou seja, a da classe dominante. Essa classe, ao deter seus próprios meios, os usaria no sentido de fazer prevalecer seu poder. Por essa razão, considera-se de fundamental importância, do ponto de vista da análise marxista, decodificar a natureza da comunicação, além de identificar os detentores desses meios e a natureza das mediações

2 As reflexões marxistas sobre a comunicação têm se pautado justamente na tentativa de explicar a influência das relações materiais sobre a ideologia. Assim, algumas contribuições de teóricos marxistas sobressaem, como a função da propaganda nas obras de Lenin e Rosa Luxemburg, a questão da hegemonia em Gramsci, a autonomia individual da consciência em Lukács e a opinião pública em Habermas. 
estabelecidas com os demais membros da sociedade. Para atenuar o monopólio da informação, a saída apontada se direcionava na elaboração de jornais de classe, ou seja, jornais para defender os trabalhadores e seus pontos de vista.

Se o marxismo contribuiu para dar um sentido à comunicação e, consequentemente, à sua função histórica, o mesmo pode ser dito do funcionalismo. Como apontávamos nas linhas anteriores, mais ou menos na década de 1950 os estudos sobre jornalismo nos Estados Unidos representaram um momento de inflexão na construção da história da comunicação social. Como proposta investigativa, o funcionalismo sugere a ideia de direcionar a pesquisa social para identificar as consequências, os fins e as funções do objeto de estudo. Desse modo, pretendia decodificar a realidade social, entendida como um sistema estrutural em que as ciências sociais, incluindo nelas a comunicação, deveriam analisar e desvendar o sistema de interações contidas nas estruturas da sociedade em questão. A comunicação, nessas circunstâncias, teria como função principal estabelecer uma relação multidirecional e dinâmica entre os diversos elementos envolvidos, desde a emissão até a recepção das mensagens.

Por essa razão, o funcionalismo procura descobrir a eficácia da comunicação mensurando seu alcance e apontando suas possíveis limitações. Metodologicamente, tal princípio demandava o estudo dos componentes do sistema comunicativo como os atores, meios ou mensagens e sua correspondência com outros fatores responsáveis pela constituição da estrutura social. Na trajetória do funcionalismo, adotaram-se diversos mecanismos para avaliar como se processava a influência da comunicação na sociedade. Consolidaram-se, na evolução dessa caminhada, as pesquisas de audiência, que têm tanto valor na atualidade. Como resultado dessas pesquisas, o funcionalismo percebeu que a comunicação interferia com seu conteúdo não apenas na formulação e consolidação das relações sociais, mas também em atividades pouco estudadas como o entretenimento e o lazer.

Entretanto, desde o final da Segunda Guerra Mundial, a persuasão política e o papel das campanhas para divulgar candidatos e propostas dominaram a preocupação dos funcionalistas. Afinal, se a 
sociedade dependia do modelo político, nada mais relevante do que ver como as pessoas respondem às propostas de seus futuros dirigentes. Não podemos nos esquecer de que naquele momento, marcado pela guerra fria, de modo subjacente ao tema comunicação e política, se encontrava a convicção dos funcionalistas, os quais acreditavam residir na política a chave para a explicação do funcionamento social.

Uma das contribuições mais relevantes do funcionalismo diz respeito à categoria de sistema, entendido como um modelo estrutural no qual se pautam as relações entre a comunicação e seus fatores externos. A integração de diversos sistemas constituiria o que conhecemos como estrutura social. No sistema social, cada subsistema pode ser estudado isoladamente, de maneira mais detalhada, permitindo decodificações de como se estabelece a trama social e como cada um dos seus componentes pode agir e influenciar a construção da teia social. Justamente nesses estudos, a comunicação recebeu um tratamento especial pelos funcionalistas, pois a consideravam um elemento relevante na hora de intervir no sistema social, permitindo que as condutas individuais estivessem de alguma forma determinadas pelos interesses de grupos comunicacionais mais amplos e poderosos.

Dentro dessa corrente, os autores identificados como os propulsores da história da comunicação social são os canadenses Harold Innis e Marshall McLuhan. ${ }^{3}$ McLuhan tentou identificar os componentes que determinam as condições de equilíbrio e de continuação nas sociedades, nos impérios e nas civilizações. Via nas tecnologias usadas na comunicação os fatores desencadeadores do nascimento e consolidação do sistema social, assim como os marcos de dominação política. Imbuído dessa crença, percebia que a comunicação - entendida como o conjunto de relações e técnicas - estabelecia um marco determinante sobre as formas vigentes em cada época e em

3 McLuhan introduz expressões de bastante impacto como "o meio é a mensagem" e "aldeia global”. Nesses termos, procurava sintetizar suas ideias centrais. Por exemplo, com a noção de "aldeia global" queria alertar no sentido de que o progresso tecnológico estava reduzindo todo o planeta à mesma situação que ocorre em uma aldeia, ou seja, a possibilidade de se intercomunicar diretamente com qualquer pessoa que nela vive. Ver as obras usadas na bibliografia final. 
cada era. McLuhan acredita numa convicção profunda: as mídias definem o ambiente do homem e da sociedade, alterando todos os aspectos da vida.

Já Innis procurou compreender as causas, o sentido e a direção das mudanças consecutivas à invenção das novas mídias e de seu impacto na vida social. A mídia produz e reestrutura padrões de interdependência social, todo aspecto da vida pessoal e seu relacionamento social. A evolução das mídias constitui o principal fator explicativo determinante da história humana. ${ }^{4}$

Uma derivação importante proveniente da visão funcionalista se encontra na teoria da modernização. Nela se considera a comunicação de massas, principal responsável pelo progresso e pela modernização das sociedades, como um dos elementos fundamentais na evolução social. Defende-se a ideia do poder efetivo e real de interferência dos meios de comunicação de massa. Na construção social, as pessoas materializam suas representações e crenças influenciadas pelas mensagens veiculadas pela mídia. Na comunicação, sob essa ótica, se conduziriam e socializariam os componentes e valores culturais desencadeadores de qualquer processo de mudança.

A relevância das contribuições expostas anteriormente se encontra no fato de apresentar uma interpretação racional e científica sobre a relação dos meios de comunicação e as transformações sociais. Como fruto dessa valorização, ocorreu a vinculação sistemática da comunicação na academia, chegando a merecer, paulatinamente, um destaque importante na compreensão da sociedade e na valorização das fórmulas simbólicas e culturais.

Posteriormente à década de 1960, os estudos da história da comunicação social seguiram dois caminhos bem diferenciados. $\mathrm{O}$ primeiro, mais descritivo e geral, procurou identificar nos processos

4 Innis, menos conhecido, realizou estudos mostrando como a comunicação é dominada por determinados grupos que, via meios de comunicação, exercem o equilíbrio, fazendo valer determinados pontos de vista do seu interesse. Agradeço ao professor Gaëtan Tremblay, da Universidade de Toronto, por esses esclarecimentos concedidos gentilmente no V Enlepicc, realizado em Salvador, em 2005. 
globais fatores da transformação social de um determinado período, inserindo a comunicação como um elemento a mais entre os responsáveis pelas mudanças. A comunicação, desde essa perspectiva, aparecia como elemento coadjuvante, perdendo sua originalidade e peculiaridade na modificação social. O segundo seguia rumos diferentes na medida em que procurava ver, de maneira mais restrita, o impacto da comunicação (ou, pelo menos, dos temas veiculados nos meios de comunicação) nas transformações das sociedades. A segunda trajetória nos interessa mais por privilegiar a relação entre as dinâmicas das mudanças estruturais e a informação oferecida pelos meios de comunicação.

A história, suas teorias, métodos e abordagens, assim como o funcionalismo e o marxismo, também contribuíram na consolidação da história da comunicação social. Logo após a Segunda Guerra Mundial, na França a história experimentou um movimento de grandes transformações se comparado com a predominância de modelos anteriores, notadamente os afinados com o positivismo (Febvre, 1986). Não se pretende, neste texto, descrever seus "combates", apenas pretendemos ver como, metodologicamente, a história colaborou na construção da história da comunicação social. Esse movimento, conhecido por Annales, incorporou dois modos de trabalhar a história de fundamental importância para compreender a afinidade história-comunicação. O primeiro diz respeito à interdisciplinaridade e o segundo se relaciona com o papel de destaque adquirido pelas movimentações das massas, protagonistas das transformações sociais. Sobressaem, nessa aproximação, os estudos sobre as estruturas e conjunturas econômicas, demográficas, sociais e de mentalidade, pontos importantes para a elaboração da história da comunicação social.

Mas a corrente dos Annales, no âmbito da historiografia, não conseguiu se impor sem enfrentar resistências. Os questionamentos feitos a esses autores se direcionavam no sentido de duvidar de algumas interpretações por adotarem novos objetivos, novos problemas e novas abordagens. De alguma forma, observa-se que a questão não se circunscrevia apenas ao método, mas sim à disputa por lugares na 
academia e acesso a outras vantagens. Mas não se pode negar que essa nova corrente, apesar das resistências, ia avançando de tal maneira que, nos anos 1960, já era conhecida e reconhecida em vários países europeus.

O estruturalismo dos Annales coincidiu com sua adoção na sociologia e em boa parte das ciências humanas e sociais. ${ }^{5}$ Os diversos pontos de vista provenientes dessas áreas acabariam exercendo uma forte influência na comunicação por proporcionar novas e sólidas concepções sobre o social, assim como por ajudar na periodização da história da comunicação social. Existe uma coincidência em apontar Braudel como o historiador que mais colaborou para ampliar as possibilidades de se criar uma história da comunicação social. Sabe-se que as contribuições de Braudel residem na sistematização dos conceitos de longa duração e história total.

O âmbito histórico de Braudel é a civilização e, dentro dela, procura identificar as diversas manifestações culturais. Dessa forma, a história teria uma grande capacidade para discernir o passado, ler o presente e, de alguma maneira, projetar o futuro. A ponte com a comunicação social estava construída. Braudel se preocupa com as grandes estruturas cronológicas e as manifestações da cultura contidas nelas. Essa concepção total da história será completada, no pensamento de Braudel, com a adoção de uma ordem cronológica estratificada: existe um tempo individual que se insere num tempo social muito mais amplo, e este, por sua vez, se enquadra no geográfico, este, sim, verdadeiramente estrutural. Dessa forma, encontram-se nas sociedades estruturas dotadas de longa tradição, tornando-se elementos estáveis para sucessivas gerações, agindo no sentido de impedir o avanço da história.

Metodologicamente, as contribuições de Braudel permitiram o estudo dos meios de comunicação de uma perspectiva ampla, na qual

5 Não pretendemos aprofundar a questão do estruturalismo aqui, apenas destacamos que é uma abordagem bastante utilizada para estudar e analisar a sociedade e suas inter-relações, a fim de determinar um sentido dentro de uma determinada cultura. Um bom estudo contendo mais detalhes sobre sua trajetória, abordagens e representantes pode ser encontrado em Dosse (1994). 
se deveria atentar para seus condicionantes jurídicos, econômicos, políticos ou institucionais. Ainda se pode destacar, dentro desse resgate da contribuição braudiliana à comunicação, o alerta que proporciona para a possibilidade de ligar, via comunicação, elementos aparentemente díspares entre si, ou seja, o sentido de uma determinada sociedade poderia ser encontrado estudando a maneira como ela se comportou diante dos meios de comunicação massificados.

Na década de 1970, o debate sobre a metodologia histórica gerou tentativas para reflexionar sobre a história a partir de novas perspectivas. Multiplicaram-se os enfoques, os objetos de estudo e os métodos de trabalho. Sobretudo na historiografia francesa, surgiu o interesse por temas como a vida privada, os âmbitos da sociabilidade ou os esforços para resgatar o papel da mulher e de outros sujeitos históricos, personagens portadores de uma história merecedora de interpretações e reconstituições.

No bojo dessa ampla gama de abordagens, destaca-se a contribuição de Vovelle (1987), para quem as mentalidades se formavam num jogo dialético no qual se confrontavam as relações entre as condições objetivas da vida das pessoas e a maneira como contam essa forma de vida. Apropriando-se do conceito de longa duração de Braudel, Vovelle alerta no sentido de que as mentalidades seriam um substrato permanente enterrado no subconsciente coletivo. Por essa razão, devem-se valorizar as opiniões por expressarem uma posição explícita, assumida com clareza por um determinado segmento social. As relações com as possibilidades de se escrever a história da comunicação social são frutíferas. Os meios se inseriam dentro das mediações propostas por Vovelle, ajudando na reprodução de cosmovisões portadoras de elementos que interferem na consolidação da sociabilidade.

Se até aqui privilegiamos a visão francesa na relação história-comunicação, agora entraremos brevemente na contribuição inglesa na construção da história social da comunicação. O marxismo, na ilha, viveu em condições bastante especiais. Preservado na academia, seguiu uma trajetória singular, pois se opôs ao determinismo econômico, ressaltou a importância do subjetivo nos processos de 
mudança e valorizou o papel social dos agentes responsáveis pela transformação social. Dessa maneira, a problemática dos historiadores britânicos acentua temas diversos, como o estudo do cenário onde acontecem as relações trabalhistas, as condições de trabalho, os marcos da sociabilidade ou a transição de valores na sociedade. Essas características se encontram em dois grandes autores dessa "escola britânica” como são Hobsbawm e Thompson. Suas reflexões voltadas para analisar o papel da cultura na sociedade são fundamentais para entender a relevância do papel da comunicação na estrutura social.

Numa de suas obras, A era do império, Hobsbawm (2007) afirma que os meios de comunicação, no final do século XIX, se mantiveram ativos e progrediram em razão das mudanças tecnológicas experimentadas naquele momento. Ele coloca os meios dentro de um cenário dinâmico e segmentado, servindo tanto aos interesses dos grupos dominantes como aos excluídos do sistema. A comunicação, tal como é vista por esse autor, se insere em um fenômeno social ligado ao meio material, às técnicas e à capacidade de assimilação ou contestação. Essa interpretação se assemelha à apresentada por Thompson (1987) na sua obra clássica sobre o operariado inglês, na qual relaciona a classe operária à influência de determinadas macrovisões culturais. As classes se constituem em relação às experiências comuns e aos mecanismos de percepção e comunicação que constituem suas identidades. A formação de opiniões decorre desse duplo processo, o fator contextual e a incorporação de valores contidos nas tradições e demais referências culturais com as quais os trabalhadores mantêm contato. Podemos pensar como, do ponto de vista dessa abordagem, os meios colaboram de maneira bastante ativa na formação de pensamentos e visões expressos nas manifestações culturais da sociedade. Escrever a história da comunicação social seria, então, mostrar esse relacionamento de interferências capazes de alterar costumes, tradições ou de dialogar com novas interpretações criadas pela exposição da informação na sociedade.

Essas duas visões coincidem com as interpretações da cultura dos autores incluídos nos denominados estudos culturais ingleses como Raymond Williams (1992) ou Stuart Hall (2005). De fato, 
a adoção da dialética como método, o cuidado com os fenômenos culturais coletivos, o interesse pela narrativa e o posicionamento contrário ao determinismo ocasionado pelos meios sobre as massas representam ideias consolidadas nos estudos culturais e na historiografia britânica. ${ }^{6}$

As ideias anteriores tiveram ressonância na América Latina e, de certa maneira, acabaram acompanhando as mesmas etapas e problemáticas na construção, no continente europeu e nos Estados Unidos, da história da comunicação social. Os registros de estudos sobre a comunicação na América Latina, de acordo com Marques de Melo (2003), remetem à segunda metade do século XIX, quando Fernandes Pinheiro estudou as estratégias evangelizadoras dos jesuítas. Do mesmo autor, datam de 1859 as abordagens analíticas para questionar a primazia lusitana na introdução da imprensa em território brasileiro, contrariando algumas obras que atribuíam tal feito aos invasores holandeses do século XVIII. Procedimentos semelhantes aconteceram no resto dos países da América Latina, tendo em comum, ainda no século XIX, seu caráter descritivo e não analítico.

A entrada da comunicação na Universidade na América Latina remonta ao ano de 1934, quando a Universidade de La Plata, em parceria com a Universidade Columbia e com o Sindicato dos Trabalhadores da Imprensa de Buenos Aires, cria o curso de Jornalismo. No Brasil, no ano seguinte, a Universidade do Distrito Federal, na cidade do Rio de Janeiro, lançou o primeiro curso superior destinado a formar jornalistas e publicitários. A intenção predominante nesses cursos residia no caráter profissionalizante, ou seja, havia a preocupação em formar mão de obra e não especialistas na construção de um saber específico relacionado aos meios de comunicação. Contudo, na medida em que se abriam as possibilidades de ampliar os estudos e de ter contato com obras e autores reconhecidos como especialistas, a situação se alterou, resultando na crítica ao modelo implantado pelos professores norte-americanos.

6 Uma boa avaliação dos estudos culturais pode ser encontrada em Escosteguy (2001). 
Numa primeira avaliação sobre as origens universitárias dos estudos da comunicação, Herscovitz (1995) é categórica ao afirmar que

[...] diante da neutralidade científica defendida pelos acadêmicos norte-americanos $[\ldots]$ os latino-americanos se dedicam com mais freqüência à pesquisa sobre interesses de classe e propriedade dos meios de comunicação, utilizando como referência teórica obras de autores como os frankfurtianos Adorno, Horkheimer e Benjamin e os marxistas Gramsci e Althusser.

Martino (2007) apresenta o motivo pelo qual tal fato aconteceu. Ocorre que, na década de 1960, a preocupação em mostrar a luta política pelo reconhecimento da natureza extremamente estratégica da comunicação e de seus produtos midiáticos residia no fato de se entenderem tais produtos como mecanismos de defesa e de preservação da identidade nacional. Existia "uma luta" para evitar a homogeneização induzida pela tecnologia que, aos poucos, massificava e comercializava a comunicação na maioria dos países latino-americanos. Outro motivo gerador desses posicionamentos mais críticos relacionava-se à introdução de grupos privados no setor da comunicação de massas. ${ }^{7}$

Esses grupos midiáticos, influenciados e com o apoio indireto de capital americano, apareciam como suspeitos de promover uma nova colonização econômica, via cultura, capaz de criar consumidores destinados a perder sua identidade cultural. Os pesquisadores identificados com tal abordagem expressavam, em suas obras, uma forte preocupação com a importância da cultura na construção de uma nova realidade mais justa e igualitária, tendência presente até

7 Esse modelo seguiu o padrão norte-americano, reconhecido como um sistema no qual a defesa pela liberdade de expressão veio acompanhada pela livre-iniciativa na detenção dos meios. Já em alguns países da Europa, notadamente na Inglaterra, o modelo estatal prevalecia. No caso brasileiro, aceita-se que a entrada dos meios de comunicação não coube ao Estado, e, sim, à iniciativa de alguns empresários que acabariam criando grandes oligopólios, verdadeiros impérios da mídia. 
os dias atuais. Por essa razão, a presença estrangeira era vista como perigosa e contrária aos processos de transformação social, urgentes no continente. $\mathrm{O}$ curioso, nesses estudos, tal como mostrado anteriormente, é o fato de utilizarem autores como Adorno, Horkheimer, Benjamin, Gramsci e Althusser, ou seja, europeus, para fundamentar sua argumentação, deixando de lado pesquisadores mais voltados para a realidade latino-americana. ${ }^{8}$

O processo de urbanização intensa, logo após a Segunda Guerra Mundial, refletiria nas análises sobre a comunicação no continente. Efetivamente, as pessoas que chegavam aos grandes centros urbanos, como São Paulo, Rio de Janeiro, Buenos Aires, Cidade do México ou Santiago, acabaram expostas aos meios de comunicação de massa (notadamente o rádio e a televisão) de maneira muito rápida. A preocupação com "as massas" alentava pesquisas destinadas a denunciar a alienação promovida pela comunicação, que se valia da população analfabeta, presa fácil de sofrer manipulação, deslumbrada pelo fascínio apresentado pelos meios de comunicação.

A Unesco, ao responder aos debates sobre a interferência da comunicação na cultura e na vida das pessoas, acabou entrando no assunto. Dessa maneira, dois grandes centros de estudos foram criados. O primeiro data de 1957 e foi sediado no Instituto Universitário de Estrasburgo; o segundo, na cidade de Quito, Equador, em 1959, o Centro Internacional de Estudos Superiores de Comunicação para América Latina (Ciespal). Tal medida representaria o fator-chave para que a comunicação adquirisse o status de ciência na América Latina. Entretanto, deve ser notado que, no mesmo ano, na Venezuela, com orientação diferente do Ciespal, funda-se o Instituto Venezuelano de Investigações da Imprensa. O embate dos representantes dos dois institutos aconteceu no Primeiro Encontro Latino-Americano

8 Ao seguir a proposta de alguns pensadores da escola de Frankfurt, cometeram-se alguns equívocos, como aceitar que na América Latina existia uma comunicação de massa, o que as estatísticas desmentem. O acesso aos meios de comunicação, nas cidades, acabou sendo facilitado, sem dúvida, mas só em algumas delas, uma vez que a penetração dos meios nos diversos países seguiu trajetórias e rumos diferenciados, porém sempre lentos. 
de Comunicação, em 1973, na Costa Rica. Lá, o Ciespal tornou-se alvo de críticas por defender um posicionamento claramente norte-americano, desvirtuando o intuito de uma comunicação do continente. O método funcionalista, considerado acrítico e conformista, apareceu como o principal vilão dessa história. Ao final, ao estudar as partes, esquecia-se de analisar o conjunto da sociedade, resultando em abordagens totalmente parciais e não representativas do todo social.

Nesse embate, emergia uma nova maneira de entender a comunicação na América Latina. Fundamentados nos métodos propostos pelos frankfurtianos para conceituar o imperialismo cultural e tendo como pano de fundo a Teoria da Dependência, emergem os estudos destinados a criticar o caráter mercantilista e consumista da comunicação. Abria-se, dessa forma, a possibilidade de se iniciar uma série de trabalhos nos quais a militância política e a comunicação andavam de mãos dadas. Martino (2007) alerta que essa mudança não implicou, necessariamente, uma maturidade teórica na construção de uma metodologia peculiar à América Latina e muito menos a construção de uma história social da comunicação. Por sua vez, as universidades - como aconteceu no Brasil, quando, em 1972, a Universidade de São Paulo e a Federal do Rio de Janeiro abriram espaço para os estudos de pós-graduação - prosseguiram na tentativa de consolidar o pensamento latino-americano de comunicação. ${ }^{9}$

Segundo Herscovitz (1995), o surgimento da nova linha de investigação, preocupada com a questão social, coincidiu com a proliferação de escolas de comunicação e de grandes transformações sociopolíticas. Os desdobramentos originados naquele momento deixaram clara a divisão entre as escolas crítica e empírica no continente. Os principais temas da escola crítica incluíam a comunicação de massa e a cultura (imperialismo cultural), a formação de monopólios, a

9 Essa ideia ainda cria polêmicas entre os estudiosos da comunicação na América Latina. Apenas para ilustrar, Marques de Melo defende a ideia de escola de pensamento latino-americano, e Orozco, renomado pesquisador mexicano, prefere falar em tendência, e não em escola. Entretanto, ambos coincidem na hora de apontar a preocupação com o social como uma característica dos estudos latino-americanos da comunicação. 
comunicação alternativa, a transnacionalização da cultura e a cultura popular. Sua fundamentação teórica se baseava na investigação da estrutura e do conteúdo ideológico da mídia. Já a empírica se preocupou com a parte formal da comunicação sem relacionar seus temas com as repercussões sociais.

No final da década de 1970, as transformações ocorridas no continente, traduzidas na aguda crise econômica e na forte mobilização popular, acabaram influenciando a consolidação dos temas peculiares à comunicação crítica. Para Marques de Melo (2003), o desencadeamento da crise dos anos 1970 e a abertura política no continente se espelham nas pesquisas de comunicação. Tais pesquisas, além de prosseguirem com a denúncia social, refletiram sobre as formas e possibilidades de construir modelos de comunicação mais democráticos. Essa inquietação prosseguiu na década de 1980.

Consolidadas as democracias no continente latino-americano, pelo menos nos seus aspectos formais, adentra-se na década de 1990 com uma ampliação dos temas relacionados à comunicação. Assuntos como o restabelecimento da liberdade de imprensa, o crescimento da indústria da comunicação dirigida pelo capital privado, a adoção de uma economia de mercado fortemente apoiada em vínculos internacionais, o uso das novas tecnologias nos meios de comunicação, além de uma possível integração socioeconômica entre os países da região, constituíam as pautas mais relevantes dos estudiosos da comunicação. De acordo com Martín-Barbero (2007), passou a existir, no início dos anos 1990, uma valorização da cultura e de sua função de mediação entre o sistema social e a vida cotidiana das pessoas. Para dar conta dessas questões, Martín-Barbero propõe um projeto transdisciplinar entendido não como a dissolução de seus objetos nos objetos das ciências sociais, mas como a construção das articulações que marcam sua especificidade para pensar, do prisma da comunicação, os mais diversos tipos de temas. Na opinião de Raul Fuentes (1999, p.65),

[...] desde a comunicação seriam observados os processos e as dimensões que incorporam perguntas e saberes históricos, antropológicos, 
estéticos, ao mesmo tempo que a história, a sociologia, a antropologia e a ciência política se encarregam dos meios e dos modos como operam as indústrias culturais.

Berger (2001, p.268) resume de maneira bastante precisa a tendência da pesquisa comunicacional na América Latina nos anos 1990. Constata o relacionamento da comunicação com o cenário da cultura que, na América Latina, encontra eco na sua formação híbrida, capaz de gerar múltiplas mediações na recepção das mensagens. Nessa nova abordagem, nem a ideologia nem a dependência foram abandonadas. Agora se inserem dentro da problemática da globalização e da mundialização. De alguma maneira, nos programas de pós-graduação, lócus privilegiado da pesquisa em comunicação, "persistiram os estudos, porém com mais rigor e qualidade teórica e metodológica sem perder a já tradicional vertente de compromisso com a transformação social".

Nas páginas anteriores, procuramos ver as diversas abordagens das quais resultam interpretações relacionadas à construção da história da comunicação social. Metodologicamente, ainda devem ser tomados alguns cuidados que passamos a explicitar. É importante lembrar que as mensagens midiáticas são apreendidas pelos receptores de modo diferente, de acordo com os códigos específicos do seu tempo. Cada geração recebe os fatos de maneira própria e peculiar. Por esse motivo, as mensagens devem ser entendidas e analisadas da maneira mais fiel possível, tarefa árdua conseguida na medida em que se usa a interdisciplinaridade no intuito de se municiar do maior número de dados possível. ${ }^{10}$ Ainda, no que se relaciona a essa questão, convém notar que a forma de comunicar de cada meio também difere com o

10 Pelo exposto, fica claro que, apesar de convicções pessoais, a reconstrução da história social da comunicação não pode ignorar as correntes e contribuições apresentadas até este momento. Por esse motivo, acreditamos que se trata de uma ciência em construção que ainda deve definir seu campo de atuação e saber realizar perguntas pertinentes a seus objetos, métodos e abordagens. Usar as outras experiências provenientes das áreas de humanas é fundamental, mas as perguntas-chave têm de privilegiar o enfoque comunicacional. 
passar dos tempos. Contextualizar, nessa perspectiva, ultrapassa a preocupação cronológica. Exige estudo minucioso da maneira como um determinado período coloca valores, crenças, atitudes e demais componentes na elaboração da sociabilidade. Não se pode entender, por exemplo, a televisão da década de 1960 com os olhares da década de 1990 ou dos dias atuais.

Outro ponto a ser considerado diz respeito à própria produção $e$ emissão das mensagens dos meios. Sabe-se que na produção cinematográfica o tempo de elaboração do produto é lento, permitindo a colocação de mensagens mais detalhadas e completas, passíveis de ser corrigidas ou de dialogar mais profundamente com os temas do momento. As possibilidades na construção de um produto cinematográfico, pelo menos até o surgimento da internet, podiam usar o tempo e o espaço de maneira bastante eficaz. Nada impedia valer-se de recursos de outras épocas para ilustrar determinadas passagens ou acontecimentos. Nunca se deve esquecer que o objetivo final da comunicação são as pessoas receptoras das mensagens produzidas pelos meios. A tecnologia e as mensagens, sem dúvida, adquirem um papel relevante na construção da comunicação e em como ela traçou sua trajetória. Entretanto, para os estudos da comunicação sob uma perspectiva histórica, a questão central residirá na forma de abordar os efeitos e mudanças na sociedade ocasionados pelos meios.

Afinal, as pessoas expostas às mensagens reagem de maneiras diferentes, não se podendo pensar num comportamento padrão, universal, aplicável a qualquer contexto ou situação determinada. Tal questão demanda dos historiadores da comunicação social a procura de novas interpretações, novos enfoques e novas avaliações dos efeitos das mensagens sobre as pessoas num contexto específico. Sem dúvida, deparamos com um desafio acentuado: como interpretar os acontecimentos e a informação recebida pelas pessoas e como avaliar seus impactos na sociedade? Essa questão pretende ser respondida com os estudos de caso apresentados no último capítulo deste livro.

Feitas essas ressalvas, resta definir a natureza da comunicação social, ou seja, qual é seu objeto de estudo e como o trata. O objeto de estudo são os meios de comunicação e seus impactos sociais. En- 
tretanto, assinalar o objeto não revela as questões mais problemáticas encontradas na construção da história social da comunicação. Um dilema crucial nessa trajetória reside nos próprios pesquisadores. O número de pesquisadores com formação específica em comunicação social, preocupados com a história dos meios, é reduzido. As tentativas de elaboração da história social dos meios partiram de pessoas com formação em áreas correlatas com a comunicação como História, Letras, Sociologia, Filosofia ou Antropologia. Os resultados dessas contribuições, frequentemente, mostram não só o desconhecimento da natureza da comunicação social, mas também uma constante confusão entre o que supõem ser a comunicação e as especificidades da sua área, resultando em obras pouco rigorosas em relação aos objetos estudados.

A herança dos estudos iniciais persiste na literatura mais contemporânea, marcando, dessa maneira, uma presença significativa na construção da história da comunicação social. Os exemplos de Harold Innis e Marshall McLuhan, vistos anteriormente, ilustram bem essa questão. Suas marcas se encontram facilmente em publicações recentes, mesmo que seja, apenas, para realizar uma atualização da problemática dos "pais fundadores", como ocorreu com a noção de aldeia global de McLuhan.

As fontes principais na construção da história da comunicação social giram na interação estabelecida entre os meios e as pessoas, o que demanda cuidados especiais. Qualquer informação tornada pública por um meio da comunicação dificilmente não virá carregada de sentido e de interesses, seja de quem a escreveu ou do grupo detentor do meio de comunicação no qual se encontra inserida. Os meios são parciais. Mesmo seguindo determinados códigos de ética, revelam fatos ou acontecimentos mediados. Tomando como exemplo um jornal da década de 1930, este não poderá ser visto e abordado com a definição atual de jornalismo, política, sociedade ou cultura. Com toda certeza, o(s) interesse(s) do(s) grupo(s) que publicava(m) $\mathrm{o}(\mathrm{s})$ jornal(ais), seu conhecimento tecnológico e seu sistema de crenças e acesso às informações diferem, substancialmente, de como se processam os mesmos itens na atualidade. 
Além do mais, os comunicadores descrevem parcelas da realidade na qual se constroem representações dirigidas por pessoas portadoras de uma visão de mundo e de um posicionamento individual e ético diante dos mais diversos temas abordados pelos meios. O que hoje entendemos como fonte, no passado não necessariamente adquiria essa categoria. Por esse motivo, não se pode pensar que um jornal seja isento ou imparcial nas notícias que veicula. Cada época e cada país reagiram e estabeleceram parâmetros nos quais se enquadravam os meios de comunicação, motivo pelo qual o estabelecimento de categorias universais, inflexíveis e padronizadas torna-se um fator de risco na hora de construir os parâmetros da história social da comunicação.

Na tentativa de ampliar os estudos e superar os dilemas da parcialidade ou o fato de privilegiar determinadas fontes em detrimento de outras, os pesquisadores preocupados com a reconstituição da história da comunicação social partiram na busca de diferentes mecanismos destinados a elucidar e compreender o papel dos meios. Assim, adquiriam evidência as buscas de documentação como o estudo do marco legal regulamentador das políticas públicas de determinada época, os documentos ligados à área administrativa das empresas de comunicação, envolvendo balanços, contratações, aquisições de materiais técnicos e arquivos. Esses elementos passaram a complementar o quadro nos quais os meios operavam. À medida que os especialistas em comunicação produziam seus trabalhos de maneira detalhada e completa, com a junção de várias informações provenientes de diversas fontes, a construção da história da comunicação social conseguiu ter mais material, podendo realizar afirmações mais aprofundadas e críticas. Contudo, uma ressalva merece ser apontada. Não se encontram obras copiladas sobre as origens da comunicação, o que resulta numa lacuna na hora de elaborar sua trajetória.

A ausência de estudos sobre as origens e os desdobramentos dos meios de comunicação social evidencia a existência de uma brecha relevante, difícil de ser preenchida, indispensável para compreender não só as origens dos meios de comunicação, como também sua evolução no transcorrer do tempo. Esse vazio impediu que pudessem 
ser realizadas obras de caráter epistemológico necessárias para se concretizar uma história dos meios assentada em bases sólidas de conhecimento. Vale a pena destacar que a inexistência desses estudos torna-se mais crítica à medida que nos afastamos dos tempos mais recentes e deparamos com países onde a preservação, como política das empresas privadas ou públicas, demorou muito para ser adotada.

De alguma maneira, essa carência parece compreensível, pois seria uma utopia pensar que as emissoras de rádio, por exemplo, tivessem arquivado todos os seus programas desde o momento em que começaram a operar. Claro que sempre restam dados alternativos como a divulgação da programação nos jornais, mas a compreensão do conteúdo e da maneira como eram produzidos, fatos relevantes para entender sua relação com a sociedade, fica claramente comprometida. Uma exceção parece ter acontecido com os jornais. Os arquivos sobre esses meios, além de serem mais completos, se preservaram em vários países, permitindo que a organização da história do jornalismo impresso esteja mais desenvolvida se comparada à dos outros meios.

A inexistência de trabalhos comparativos, destinados a identificar como se construíram as trajetórias de cada meio e, inclusive, para ver se um meio influenciou os outros, faz que sua história não possa ser estabelecida com segurança, dificultando as tentativas de situar momentos e características específicos na consolidação dos meios de comunicação social. A elaboração dos fundamentos e metodologias se encontra em constante construção, recebendo invariavelmente contribuições destinadas a estabelecer novas revisões e periodizações. Entretanto, essas idas e vindas não têm impedido a realização de tentativas no sentido de elaborar trabalhos mais teóricos e reflexivos sobre a história da comunicação social.

A reversão dessa tendência ocorre, na atualidade, por causa, em parte, do impulso proveniente dos estudos de comunicação realizados nas universidades. $\mathrm{O}$ aporte de trabalhos dos estudos dos meios, enfatizando sua trajetória regional nas quais se privilegiam os estudos das peculiaridades e especificidades, emerge, dando à comunicação 
um maior suporte teórico e clareza na hora de se falar do seu objeto, dos métodos e das fontes de estudo. ${ }^{11}$ Aliás, parece ter se chegado a uma situação extrema na qual se aceita a ideia de que a comunicação representa um vetor decisivo na construção da sociabilidade contemporânea. Fica difícil imaginar uma sociedade onde as pessoas não fiquem expostas, por muito tempo, aos meios de comunicação e, consequentemente, ao conteúdo divulgado neles.

Contudo, a aparente proliferação dos estudos da história da comunicação social aponta alguns itens problemáticos relacionados à metodologia. Normalmente, há uma similaridade entre a história da comunicação social e a do jornalismo. Como o jornal e o jornalismo impresso apresentam registros mais completos do que os outros meios de comunicação, como apontávamos anteriormente, há uma tendência a relacionar a história do jornalismo com a da comunicação social. Mas a história da comunicação social demanda estudos específicos para cada meio de comunicação, pois os métodos, as definições e a periodização realizada no jornalismo impresso não servem para o rádio, a televisão ou o cinema, e muito menos para a internet.

O eixo da construção da comunicação social reside no reconhecimento das nuanças de cada meio, no estudo de suas repercussões na construção da sociabilidade e na formação e divulgação de ideias e valores. A essa questão é necessário acrescentar uma outra. Cada meio se torna público num determinado momento específico e numa realidade particular. Considerar o tempo e espaço no qual se veiculou representa outro fator relevante na compreensão de sua atuação. $\mathrm{O}$ resultado dessa interação é, justamente, a área de interesse da história da comunicação social.

Nela podem-se identificar as leituras peculiares realizadas por determinados grupos sobre os meios de comunicação. Há uma relação dialética entre os fatos, sua divulgação e alcance na transformação

11 Diversos projetos têm aparecido no sentido de sistematizar as possibilidades de se escrever a história social dos meios. Um exemplo importante, no nosso país, é o realizado pela Rede Alcar. O endereço eletrônico fornece uma boa visão das linhas adotadas nas suas pesquisas: http://www.jornalismo.ufsc.br/redealcar/. 
social. Pode-se investigar até onde os meios ocasionaram ou interpretaram os fatos ou, ao contrário, delimitar em que circunstâncias os meios espelharam apenas alguns fatos, ignorando outros - questões que emergem de maneira proeminente no que tange à construção histórica da comunicação social.

Ao defender tal posicionamento, adotamos um ponto de vista bastante claro: a comunicação ocorre apenas quando chega ao receptor, depositário final dos efeitos comunicativos provenientes das informações publicadas nos meios de comunicação, e repercute na consolidação da sociabilidade. Obviamente, os avanços tecnológicos e a complexidade dos conteúdos oferecidos pelos meios tornam-se relevantes, mas não decisivos na construção da história social da comunicação. A informação veiculada pelos meios age num determinado grupo social concreto, dentro de uma conjuntura, promovendo reações, sem as quais seria uma atividade irrelevante para a sociedade.

Do exposto anteriormente, podemos inferir que a comunicação social acontece e aparece como resultado da ação dos meios num espaço e tempo concretos. Ao historiar a trajetória dos meios de comunicação, não se deve perder o foco central, ou seja, a comunicação e sua transcendência num determinado grupo social. Excluímos, neste texto, intencionalmente, a comunicação interpessoal, ou seja, aquela que não tem sua manifestação social conhecida. Não ignoramos a existência de outros tipos de comunicação, mas, como apresentam mais resultados individuais do que sociais, não serão tratados nesta oportunidade. Apesar das lacunas e carências de estudos na temática da história da comunicação social, uma alternativa, para equacionar essa deficiência, se encontra no aprofundamento do estudo das formas da articulação da comunicação com as transformações sociais. A história da comunicação social deve privilegiar análises e explicações das funções que têm desenvolvido os meios nas diversas sociedades no transcorrer do tempo, assim como sua transcendência explícita para o presente.

Diante desse quadro, a questão relacionada à comunicação social como agente articulador nas sociedades merece algumas reflexões. Teoricamente, não existe discrepância quando se pensa a comunica- 
ção social como uma das formas mais efetivas de integração social, pelo menos nas denominadas sociedades contemporâneas. Contudo, outra questão mais problemática diz respeito à comprovação dos efeitos da comunicação nas sociedades, com que intensidade e em que condições ocorrem, questão essa respondida pelo uso de determinadas metodologias preocupadas em relacionar a comunicação com seu papel social. Inevitavelmente, a informação exposta nos meios, informação entendida como fato, emerge como ponto central na relação história-comunicação, ponto de estudo do próximo capítulo. 



\title{
2 \\ O ACONTECIMENTO HISTÓRICO E O ACONTECIMENTO COMUNICACIONAL
}

\author{
"Não é a consciência do homem que lhe de- \\ termina o ser, mas, ao contrário, o seu ser social \\ que lhe determina a consciência." (Karl Marx)
}

Existe uma clara diferença entre o acontecimento tal como é entendido e abordado pela historiografia tradicional e pelos meios de comunicação. ${ }^{1}$ Entretanto, ambos aceitam que o acontecimento deriva do fato entendido como o episódio desencadeador de mudanças no status quo da sociedade. Para que passe a ter destaque, deve se encaixar dentro de um processo social no qual se atribui, ou não, relevância, uma vez que interfere nas relações sociais. $\mathrm{O}$ acontecimento existe em função do relato feito dele. Justamente na construção desse relato, a história e a comunicação se encontram, pois criam versões de suas especificidades. Para a história, o resgate do acontecimento implica a possibilidade de se exercitar a cientificidade manifesta na

1 Neste texto, usaremos o acontecimento como a produção de sentido dos fatos. Pierre Nora (1995, p.184) exemplifica essa diferença apresentando vários fatos, e um deles diz respeito ao caso do suicídio de Marilyn Monroe. O suicídio é o fato que se torna acontecimento na medida em que milhões de pessoas veem nele o drama do star system, a infeliz vendedora que se escondia por trás da supervisora, a tragédia da beleza interrompida, a infelicidade da existência. 
elaboração de explicações úteis para a compreensão das estruturas e das mudanças. Tal procedimento facilitará o entendimento do tempo presente e do mundo no qual o historiador se situa.

Numa passagem extremadamente feliz, Le Goff(1999, p.93) tece considerações relevantes para compreender, como ele mesmo diz, o passado pelo presente e o presente pelo passado. Esse historiador, conhecido pelas suas obras relacionadas com a Idade Média, coloca uma pergunta-chave para abordar os acontecimentos dentro da ótica apontada anteriormente: houve na Idade Média fenômenos históricos que esclareçam o presente imediato? O que se passa hoje me permite melhor compreender o que aconteceu na Idade Média?

Implícito na pergunta de Le Goff se esboça um percurso para o historiador preocupado com a construção de sentido no presente. Ele vê a necessidade de se remontar a um momento passado no qual o fato se gerou. Partindo dessa definição, caberia ir apontando as mudanças (rupturas, as grandes viradas) ocorridas no transcorrer do tempo para compreender as dimensões atuais envolvidas na visibilidade do fato. Para sustentar suas afirmações, usa alguns exemplos nos quais aplica o procedimento de contextualizar e considerar os fatos dentro de uma longa duração para poder aprofundar os problemas e os dilemas implícitos neles. Dessa maneira, o acontecimento carrega um sentido compreensível, inserido numa lógica solidamente fundamentada, consistente, analisada por especialistas e estudiosos preocupados com esse dado e com a configuração adquirida no passar dos tempos.

Le Goff (1999, p.95) usa um exemplo bastante interessante para ilustrar sua preocupação: a Guerra do Golfo. O conflito, seguindo suas observações, se insere numa problemática de longa duração, na qual árabes e cristãos protagonizaram confrontos, debates e situações marcantes. Dessa maneira, ele vê nas Cruzadas um bom referencial para iniciar a compreensão do acontecimento mais imediato, ou seja, a guerra mais próxima.

Considero-as [as Cruzadas] como um pseudo-acontecimento sem grande alcance na longa duração, mas se elas fazem parte negativamente da memória coletiva muçulmana, isto muda a impor- 
tância histórica das cruzadas. Em seguida, o lugar de Israel: é ele, nesse caso, o sucessor do império latino em Jerusalém considerado por Prawer como um estado colonial? No domínio econômico as motivações econômicas das cruzadas foram fracas na Idade Média. Hoje a importância do petróleo é enorme. No domínio militar não há um desequilíbrio tecnológico nas cruzadas, São Luís em Joinville é prova disso, os cruzados ocidentais temiam o fogo-grego lançado pelos muçulmanos sobre os exércitos cristãos. Hoje a enorme superioridade dos ocidentais em mísseis inverte a situação. Mas foram dois problemas que provocaram em mim o historiador de longa duração. Diante da Guerra Santa, o Djihad dos muçulmanos, a noção de guerra justa porque dirigida contra os infiéis, não mudou hoje?

Ainda, continuando com sua problematização, Le Goff alerta para o cuidado com as fontes de informação empregadas nesse construto histórico. Defende a adoção de algumas preocupações como: uma leitura do presente, do acontecimento, com uma profundidade histórica ampla o suficiente para conseguir construir uma opinião fundamentada; aplicar um método crítico em relação às fontes, respeitando suas especificidades; procurar fugir da simples narrativa descritiva, oferecendo explicações interpretativas; e tentar hierarquizar alguns fatos, procurando saber distinguir o que é fato de acidente, pois assim será possível relacionar esse evento com o passado já interpretado e avaliado pelos historiadores ou por outros cientistas da área de humanas.

Poucas dúvidas existem na aceitação, portanto, do reconhecimento da importância dos meios de comunicação na construção da realidade social. Ao incidir sobre a formulação do cotidiano, já que sua função principal se centraliza na divulgação dos fatos por eles veiculados, acabam servindo de referência para que as pessoas formem ou rejeitem opiniões e versões. ${ }^{2}$ Os produtos midiáticos devem

2 Real e realidade têm significados diferentes. Neste estudo, o real será entendido como a relação da cada indivíduo com os fatos aos quais fica exposto. Já realidade designa os acontecimentos e sua respectiva socialização. 
ser entendidos como resultados de motivações sociais ou individuais ou da combinação de ambas. Parte dessas razões motivadoras é imperceptível nos meios de comunicação mesmo quando realizam um filtro em função das suas particularidades. Seria, por exemplo, impossível, para um jornal, pressionado pelo tempo e pelo espaço para ser publicado, desvendar ou mostrar o desencadeamento social gerado pelas notícias que coloca nas suas páginas. Entretanto, com a profissionalização dos responsáveis pela gestão dos meios de comunicação e pela divulgação e aceitação dos códigos de ética, é possível identificar nas matérias publicadas um esforço por desvendar boa parte da estrutura geradora do fato.

Mesmo com essas limitações, o acontecimento apresentado pelos meios de comunicação interfere e repercute ativamente na sociedade e nas pessoas que eventualmente puderam acessá-los. Mas, sem levar em consideração as formas como as pessoas se relacionam com eles, a interferência não teria validade. Por essa razão, é prudente trabalhar não apenas com uma fórmula ou um procedimento na hora de aferir como as pessoas estabelecem diálogos com os meios de comunicação. A flexibilidade e a adoção de métodos e procedimentos mais abrangentes são imprescindíveis para decodificar as relações entre meios de comunicação e pessoas inseridas num contexto específico.

Apenas para ilustrar como isso ocorre na prática, basta pensar nas reações de duas pessoas em situações diferentes diante da mesma informação. Se a notícia em questão afirma que os índices de desemprego diminuem, e ela é recebida por alguém que acabou de conseguir emprego, obviamente terá repercussão diferente do que para quem se encontra desempregado. Temos, portanto, duas respostas antagônicas originadas por duas situações individuais diferentes. As repercussões e versões das falas dessas pessoas diante da informação recebida serão, também, opostas e contraditórias para quem não teve conhecimento da notícia divulgada. ${ }^{3}$

3 Essa observação se fundamenta numa das últimas falas de Umberto Eco (2008) quando reflete sobre o poder das imagens e os perigos que carregam ao serem interpretadas sem uma contextualização. A exageração lança uma hipótese 
Fica clara a inserção social e ativa dos meios de comunicação na sociedade. Só isso já justifica a necessidade de decodificar o alcance e a influência deles no cotidiano das pessoas na hora de tomar decisões. John B. Thompson $(1995,1998)$, um dos autores fundamentais para nossos trabalhos, sustenta a ideia de que os meios de comunicação têm um papel decisivo na construção da sociedade moderna, chegando, inclusive, a atribuir-lhes função determinante na construção das redes sociais. Dessa perspectiva, os meios teriam um papel ativo na socialização das relações sociais, passando a constituir um elemento imprescindível na compreensão da modernidade.

Seu ponto de partida remete à valorização da comunicação, ao intercâmbio de informações e de conteúdos simbólicos que as sociedades receberam, notadamente naquelas onde a urbanização e a divulgação de informações passaram a ter papel relevante nas formas políticas, econômicas e sociais. Nessa trajetória, os meios de comunicação foram se destacando até que, de uma forma profunda e irreversível, acabaram influenciando a transformação da natureza da produção e do intercâmbio simbólico no mundo moderno, ou seja, aproximaram-se das relações de poder existentes na sociedade. Por essa razão, os acontecimentos divulgados nos diversos meios de comunicação passaram a ter expressividade notória para o cotidiano das pessoas e acabaram sendo usados pelos grupos detentores do poder para legitimar posicionamentos e pontos de vista do seu interesse.

Justamente nessas relações de poder, Thompson insere a função dos meios de comunicação. Assim entendidos, os meios desempenhariam um papel duplo: concomitantemente, seriam portadores e porta-vozes de determinados segmentos dentro da sociedade. Dessa junção resulta, segundo Thompson, uma nova forma de analisar as relações sociais às quais os meios de comunicação agregam valores simbólicos não considerados suficientemente até o momento em que

no mínimo curiosa. Imaginemos a possibilidade de o mundo ser destruído e um ser de outro planeta chegar e encontrar um quadro de Picasso. A ideia de habitantes da Terra que esse ser terá não corresponderia à realidade, mas esse fato não nos autoriza a tirar valor de como Picasso expressa sua arte para nós; conhecer a obra do artista pode ter um sentido. 
se atenta para sua inserção na sociedade. O poder simbólico emanado da produção cultural e social, alerta Thompson, teria a mesma importância e exerceria a mesma função que os poderes já considerados clássicos na construção e consolidação da sociedade, como o poder político, o econômico ou o coercitivo. Ao agregar essa nova forma pela qual circulam as relações de poder, Thompson projeta um novo fator capaz de intervir no curso dos acontecimentos, de influenciar as ações dos outros e produzir eventos por meio da produção e transmissão de formas simbólicas. Tal concepção do poder simbólico difere, portanto, da apresentada por Bourdieu (2003), para quem as pessoas submetidas ao poder simbólico não teriam o conhecimento das informações recebidas. ${ }^{4}$

Mas aceitar a visão de Thompson não é tão simples como pode parecer. Se as pessoas já tinham algum tipo de conhecimento na hora de se relacionar com os meios de comunicação e seus conteúdos, a mediação criada entre as pessoas e os meios de comunicação merece uma explicação mais detalhada. Tanto na produção como na transmissão das formas simbólicas, os meios de comunicação se servem de recursos técnicos que na sua evolução ampliaram substancialmente a capacidade de armazenar e usar conteúdos, adquirindo novas e amplas formas de interferir nas relações de poder. Veja-se, por exemplo, na atualidade, como nas mídias se mostram cenas e acontecimentos do passado sempre inseridos dentro de uma espetacularização e recriação de outras épocas e momentos bastante diferentes de como os fatos se passaram. Um filme, por exemplo, pode ser lançado simultaneamente no mundo inteiro, atingindo milhões de pessoas que irão ficar expostas às mensagens e outras significações e recriações do conteúdo da película. ${ }^{5}$

Comercialmente, a reprodução dos produtos midiáticos inicia, de maneira sistêmica, a aproximação entre o capital e o entretenimento,

4 Sobre essas discordâncias, ver Thompson (1998, p.24).

5 Imaginemos um filme de fundo histórico que recria o passado para dar sentido a determinadas cenas. Esse aspecto resulta de máxima importância, pois, além de ser visto no mundo inteiro, pode, eventualmente, criar uma visão do passado tal como pretende o diretor sem que ela corresponda à realidade da época. 
resultando na exploração comercial dos meios de comunicação e na sua apropriação pelos grupos que almejam o poder. Essa ocorrência adquire suma relevância no mundo atual. Thompson alerta para o fato de vivermos num mundo globalizado no qual a circulação dos produtos midiáticos não se restringe ao âmbito local e sim planetário. Tal divulgação, lembra, implica que cada produto, elaborado num determinado contexto e situação concreta à qual tenta dar uma resposta, se maximiza pela facilidade encontrada na sua disseminação. Dessa forma, interfere, podendo recriar interpretações sobre os fatos e demais acontecimentos apresentados.

Nesse processo de codificação e de decodificação dos conteúdos, ocorre a interação cultural na qual, nos tempos mais próximos, verifica-se não só uma padronização na operacionalização dos equipamentos, mas também uma inovação e incorporação de valores culturais. Assim, via meios materiais, chegaríamos a certa massificação dos conteúdos, o que remete ao conceito de sociedade de massas ou, especificamente, à comunicação de massas, termo infeliz, na opinião de Thompson, universalizado para designar todas essas mudanças envolvidas na aproximação das pessoas aos meios e seus conteúdos dentro da modernidade.

Estaríamos, portanto, diante de um dilema desafiador. Será que a exposição sistemática aos produtos da mídia altera a cultura e as versões criadas por esses produtos midiáticos? Caminharíamos para a uniformização de comportamentos e valores? Thompson opta por não concordar com essas indagações e abre a possibilidade da resistência e da estranheza que as pessoas podem sentir diante do conteúdo divulgado pela mídia.

A comunicação de massa, para ele, deve ser entendida como a produção institucionalizada e a difusão generalizada de bens simbólicos por meio da fixação e transmissão de informação ou sentido simbólico. Essa comunicação envolve itens importantes, entre os quais Thompson (1995, p.83) destaca

Os meios técnicos e institucionais de produção e difusão. A mercantilização das formas simbólicas; a dissociação estruturada 
entre a produção e a recepção; o prolongamento da disponibilidade dos produtos da mídia no tempo e no espaço; e a circulação pública de formas simbólicas mediadas.

O primeiro item implica considerar a interferência das indústrias das mídias sem as quais não seria possível a divulgação maciça dos acontecimentos. Entretanto, esse aspecto não adquire um caráter negativo em Thompson, ao contrário, emerge como um ponto de convergência entre os meios de comunicação de massa e as sociedades atingidas por eles. Na medida em que acontecia um deslocamento técnico dos meios, também as sociedades modernas tornaram-se mais complexas, possibilitando a diversidade de opiniões e versões.

A mercantilização das formas simbólicas, outro componente da comunicação de massa, implica aceitar que os produtos da mídia se tornam mercadoria e como tal se apresentam à sociedade. A questão central a ser pensada reside no fato de que os bens simbólicos invadem o cotidiano das pessoas, interferindo na formação de um imaginário presente na sua formação individual. Mas a massificação nem sempre ocasionaria alienação, pois, se todos os produtos simbólicos são comercializados, alguns carregam justamente conteúdos muitas vezes contrários aos propósitos econômicos da sociedade de massa. Ainda, lembra Thompson, nunca se deve esquecer que ocorre uma dissociação estrutural entre as formas de produção simbólicas, os fatos e a sua recepção. Em virtude dessa separação, por ser um fluxo de mão única, a comunicação de massa, ao ser recebida, passa por uma mediação particularizada pela trajetória das pessoas e pela própria estrutura na qual se encontra implantada.

Thompson define essa característica como a relação desigual num processo de intercâmbio simbólico. Assim, a mídia estabelece uma dicotomia entre os contextos de produção e os contextos de recepção. Dessa maneira, a comunicação de massa ganha proeminência pela capacidade que tem de penetrar de maneira rápida e ampla nas diversas sociedades, ou seja, fica disponível para um grande número de receptores. Seu conteúdo é público, mas gera repercussões no âmbito privado. 
Um desdobramento dessas particularidades da comunicação de massa diz respeito à historicidade mediada. Nessa expressão, Thompson engloba as formas pelas quais as pessoas se relacionam com o tempo passado e com a interpretação e transmissão dos fatos nele acontecidos. A massificação e o crescimento tecnológico colocam em risco as narrativas face a face e as interações sociais, fruto dessa relação. Dessa maneira, ocorre um acréscimo na hora de transmitir as experiências do passado, acréscimo esse que se dá em função da incorporação e da exposição das pessoas às mídias e aos seus conteúdos. Por esse motivo, Thompson acredita que as noções de tempo e espaço passam por transformações. O sentido de pertencimento das pessoas agora é mediado pela comunicação e pelos fatos por ela divulgados. De maneira enfática, afirma Thompson, sentimo-nos pertencentes a grupos e comunidades que se constituem, em parte, por meio da mídia.

Mas não se pode afirmar que as pessoas sejam passivas em relação aos produtos da mídia. O sentido que os indivíduos dão a esses produtos varia de acordo com a formação e as condições sociais. Os impactos e as interpretações diferem em função da trajetória sociocultural de cada pessoa. Nem sempre a pretensão dos emissores dos produtos midiáticos massificados atinge as finalidades propostas. Tão importante seria descobrir o processo de elaboração do produto midiático (interesses, fins e motivações que o geraram) como decodificar sua interpretação em função do contexto social e histórico no qual se encontra o receptor. A recepção se adiciona ao conjunto de outras atividades realizadas pelo indivíduo, ou seja, o receptor éativo, trabalha e decodifica o material simbólico recebido pelos meios de comunicação de massa diariamente.

Como Thompson (1995, p.46) mesmo lembra, de maneira bastante clara:

Nós estamos ativamente nos modificando por meio de mensagens e de conteúdo significativo proposto pela mídia (ente outras coisas). Este processo de transformação pessoal não é um acontecimento súbito e singular. Ele acontece lentamente, imperceptivelmente, dia após dia, ano após ano. É um processo no qual algumas mensagens 
são retidas e outras esquecidas, no qual algumas se tornam fundamento de ação e de reflexão, tópico de conversação entre amigos, enquanto outras deslizam pelo dreno da memória e se perdem no fluxo e no refluxo de imagens e idéias.

Para Thompson, o momento atual em que se concretiza toda essa dinâmica é diferenciado. A predominância das formas globalizadas, encontradas nos meios, indica a existência de interesses globais capazes de uniformizar os produtos da mídia para obter pessoas padronizadas. Assim, as ações, segundo Thompson, são pensadas, planejadas, organizadas ou coordenadas em esfera global, envolvendo algum grau de reciprocidade e interdependência. As atividades locais, inclusive, não fugiriam a essa lógica globalizante e acabariam criando um processo de vinculação e dependência dos grandes grupos comunicacionais representantes de interesses estranhos à vida local. Embora Thompson se preocupe com os temas ligados à televisão, suas ideias, tal como expostas anteriormente, podem se aplicar também aos demais meios de comunicação. Em razão de nossos interesses, permaneceremos no jornalismo impresso para aprofundar como se constroem os fatos nesse meio e como pode ser estabelecida sua relação com a história.

Jean-Pierre Rioux (1999), um dos autores preocupados em estabelecer pontes entre a história e o jornalismo, mostra um posicionamento categórico ao sustentar que, no caso da França, não teria vingado esse diálogo sem o esforço dos jornalistas em buscar legitimidade histórica nas suas matérias. Isso não significa que, na elaboração de seus saberes específicos, construídos no passar do tempo, as divergências entre a história e o jornalismo não ocorram. O jornalista abordaria fatos que morrem no cotidiano da edição na qual são publicados. A aparente ausência de lógica e ordenamento desses acontecimentos decorre justamente da escassez de tempo para aprofundar as notícias. Por causa dessa delimitação, Rioux (1999, p.121) sustenta que

O jornalista é o homem apressado que relata fatos juntados, que acredita entregar a vida em estado bruto, mas que a simplifica e 
desfigura mediatizando-a em jato contínuo, que recolhe material de qualquer jeito e inventa (sic) fontes sem poder tratá-las.

O historiador, lembra Rioux, desenvolve suas atividades numa outra perspectiva, marcada pelo distanciamento no qual pode refletir mais calmamente sobre os acontecimentos. Por isso, pode realizar uma crítica das fontes e trabalhar em diálogo com as outras ciências humanas, conseguindo, dessa maneira, dar ao seu trabalho

[...] um estatuto científico, pois procura sempre inserir o acontecimento singular na cadeia de um tempo significativo, tenta distinguir o perdurável do efêmero, relata os fatos sem ser perseguido pela hora do fechamento. (Rioux, 1999, p.120)

Para Rioux, a década de 1960 modificou essa relação aparentemente tão distante entre essas duas áreas do conhecimento. Deve-se a Jean Lacouture (1995), no caso francês, o esforço para estabelecer, por parte dos historiadores, uma valorização do jornalismo no sentido de entendê-lo de maneira a ultrapassar sua cotidianidade e sua superficialidade. Rioux, referindo-se ao papel desempenhado por Lacouture nessa união, salienta seu empenho em suscitar matérias mais críticas, contextualizadas, bem estruturadas e capazes de relacionar o passado com o presente. A consagração dessa aproximação aconteceria em maio de 1968, momento no qual a imprensa se destacou "na transmissão, na representação e até na produção dos acontecimentos".

Nos caminhos da conciliação, a entrada da tecnologia de maneira maciça nas redações dos jornais aumentou a quantidade de notícias que chegavam a esses veículos, obrigando os jornalistas a realizar uma seleção mais criteriosa antes de tornar público um determinado fato. Nesse momento, sustenta Rioux, a aproximação se consolidou. Efetivamente,

[...] através da informação das bases, dos bancos de dados e da própria fabricação do "papel" que se pode alimentar quase à von- 
tade no "doc", na pesquisa mais avançada e multiplicada junto aos correspondentes locais, da fabricação de dossiês tipo news, da exibição da memória arquivada do jornal que dá consistência a seu propósito, pela fama também dos suplementos que ajudam a relativizar a atualidade e a refletir sobre ela, o exame da atualidade tornou-se uma crônica durável, tomou uma textura e uma espessura que o aproximam mais de um produto histórico. (ibidem, p.123)

Sem dúvida, o papel do jornalismo numa sociedade cada vez mais midiática adquiriu relevância. Sua função mediadora, num contexto social superinformado e bombardeado constantemente por notícias provenientes das mais variadas fontes e lugares, adquiriu relevância por passar do papel de mero reprodutor de fatos a exercer a incumbência de ordenamento e interpretação desse caos. Assim, no exercício de seu cargo, sustenta Rioux, o jornalista ganha destaque e se aproxima da história para obter versões mais consistentes e estabelecer comentários claros, fundamentados, estruturados e compreensíveis para seus leitores.

Rioux observa, nessa transformação, como os historiadores também ocuparam espaços no campo midiático. Constantemente, eram convocados para apresentar explicações e interpretações "ao vivo". Na década de 1970, essa tendência se consolidou. Proliferaram e se consolidaram nos meios de comunicação novas práticas como a elaboração de documentários, séries, matérias especiais e publicações de materiais impressos com reportagens específicas. Dessa maneira, na década de 1980 os historiadores já tinham as portas abertas para a exploração do presente.

Mas essa história do presente dos anos 1980, lembra Rioux, pouco dialogou em profundidade com a história imediata - própria do jornalismo -, mantendo mais contato com outras ciências como a Antropologia, Sociologia, Economia e Etnografia, ocorrendo uma preocupação maior com a memória do que propriamente com as novas configurações que se processavam nos acontecimentos tal como divulgados pelos jornais. 
$\mathrm{Na}$ aproximação com as outras ciências, viu-se a necessidade de a história também ter "uma versão" para o que acontecia no momento atual. Afinal, as demais áreas do saber se manifestavam sobre os fatos do dia a dia sem nenhum constrangimento. Renascia uma possibilidade de aproximação da denominada história do presente e o jornalismo. Encontros entre historiadores e jornalistas acabariam dando resultados na medida em que ambos compartilharam as técnicas de cada área. O jornalismo, fruto desse contato, acabou tendo mais cuidado na escolha de determinados temas, no uso ostensivo das entrevistas para captar opiniões de especialistas e na maneira de escrever, dando mais vida aos personagens e aos fatos. Tal concepção de jornalismo se aproximava da forma como se escrevia a história.

Embora Rioux realize um esforço significativo para demonstrar essa convergência, emergem questões complexas de difícil solução. Jean Lacouture, autor que trabalha também com o contexto francês como referência, parte de uma afirmação clara: o jornalista não seria, apenas, o historiador do instante, termo emprestado de Albert Camus quando se referia a essa categoria. $\mathrm{O}$ jornalista convive com alguns perigos dos quais é difícil desvencilhar-se. O mais crítico reside no modismo das fontes e na rara prática de cruzar as informações obtidas para ter certeza de suas afirmações.

Dessa maneira, Lacouture reconhece o poder de manipulação que retém na sua atividade o jornalismo. A junção das duas áreas, vista como inevitável por Lacouture, ocorreu mais na forma do que propriamente na metodologia, ou seja, ambas passaram a ter termos comuns, mas não conseguiram procedimentos semelhantes nas apurações dos fatos tratados. Reconhece os avanços, mas constata a inexistência de obras paradigmáticas nessa conexão. Uma exceção seria Os homens do presidente, obra investigativa elaborada pelos jornalistas do Washington Post, Bob Woodward e Carl Bernstein. O motivo pelo qual Lacouture aponta esse livro como modelar reside no seu caráter final, entendido por ele como um alerta sobre as práticas denunciadas pelo trabalho investigativo dos jornalistas. De alguma maneira, eles teriam fechado uma possibilidade de exercer a política 
pelo viés negativo. O livro em si tem uma finalidade definida, se fecha, acaba com a denúncia mostrada pelos jornalistas. ${ }^{6}$

Entretanto, não é só pelo desfecho do acontecimento que o jornalismo adquire relevância. Diante da impossibilidade de publicar todas as informações recebidas, o jornalismo convive com lacunas. Os inúmeros fatos que o jornalista não valoriza às vezes determinam ou geram processos e têm mais relevância do que "a matéria que venderia ou surpreenderia mais" ao receptor. A procura pelo furo, lembra Lacouture, nem sempre beneficia o trabalho mais reflexivo dos jornalistas. Claro que o desejo de consegui-lo é inerente à profissão do jornalista e à do historiador. Afinal, que historiador resistiria à tentação de publicar, pela primeira vez, um documento decisivo para mudar determinados rumos e interpretações da própria história? Mas a pressa, em algumas ocasiões, resulta em informações totalmente descabidas.

Talvez o caso mais ilustrativo dessa atitude seja o de Timisoara, uma cidade da Romênia mundialmente famosa depois de ter ocupado as páginas dos principais jornais do mundo, nos quais se divulgava a existência de covas clandestinas com milhares de pessoas mortas numa chacinada realizada pelas forças fiéis ao ditador Ceaucescu. ${ }^{7}$

6 Um livro exemplar nessa linha, dentro do nosso contexto, é o publicado por René Dreifuss (1989): O jogo da direita. A obra começa com uma indagação-chave: seria realmente indispensável recolher documentos sigilosos, ouvir fontes exclusivas, manter encontros discretos e pesquisas em arquivos reservados, para desvendar o acontecer político? O resultado obtido é alentador e comprova que existe, sim, uma possibilidade concreta de realizar interpretações tomando como fontes as notícias publicadas pelos jornais.

7 No final de 1989, depois de um intenso embate, a Romênia derrubou Nicolae Ceaucescu, que governava esse país fazia já 25 anos. Entre os dias 15 e 22 de dezembro, Ceaucescu foi derrubado e, depois de ser preso e julgado, acabou sendo executado antes do Natal daquele ano. Os intensos combates ocasionaram notícias distorcidas e pouco confiáveis, mas que a imprensa mundial fez questão de destacar de maneira ampla, criando "um clima" contra o ditador e seus aliados. Nesse contexto, divulgou-se o suposto massacre de Timisoara, calculando-se entre 50 e 80 mil o número de pessoas assassinadas e jogadas nas sepulturas clandestinas. Depois de terminado o conflito, verificou-se que esses números não correspondiam, sob nenhuma hipótese, à verdade, e a imprensa foi obrigada 
$\mathrm{Na}$ verdade, com o passar do tempo, verificou-se que os números divulgados nos meios de comunicação não correspondiam à verdade. Os jornais, nesse caso, pelas condições internas da Romênia, pela falta de conhecimento daquele país e pela ausência de dados concretos vindos de fontes confiáveis, acabaram divulgando um fato que não ocorreu, mas que teve repercussão mundial, influenciando, inclusive, a condenação de Ceaucescu à pena de morte.

Apesar dos desdobramentos significativos de episódios como o anteriormente citado, Lacouture acredita que o jornalista continua sendo um forte candidato à "operação histórica”, uma vez que, como ator envolvido nos acontecimentos, é obrigado a ordená-los e inseri-los dentro de uma problemática que seja coerente e com sentido para o receptor. Não se pode esquecer, lembra Lacouture, das especificidades do jornalismo contemporâneo. Nele, a venda do jornal determina sua existência, motivo pelo qual, se tiver que escolher entre duas notícias, com certeza a que cause mais impacto e proporcione mais sensacionalismo e, consequentemente, lucro acabará sendo a publicada. ${ }^{8}$

Numa tentativa de esclarecer e apontar caminhos para aproximar a história do jornalismo, Lacouture usa exemplos ilustrativos das possibilidades de se trabalhar conjuntamente. Um deles, bastante esclarecedor, refere-se a um questionário elaborado pelos repórteres do Sunday Times londrino sobre o conflito árabe-israelense de 1973. Nele se colocavam questões relevantes que não deixavam escapar

a aceitar seu erro. No entanto, ela interferiu, por exemplo, na execução de Ceaucescu, o que levantou sérias questões sobre o papel do jornalismo e como ele era exercido.

8 A situação hoje é diferente. Atualmente, os jornais têm na propaganda uma fonte de renda substancial, superando, inclusive, a proveniente das assinaturas. A inversão coloca outra questão de fundo: os jornais publicariam matérias contrárias aos interesses dos seus anunciantes? Ao que tudo indica a resposta seria não. O jornal se comporta como uma empresa e, obviamente, não pode ferir seus clientes. Claro que os leitores não podem ser esquecidos. Em razão disso, a forma de apresentar as notícias vem sendo o recurso utilizado pelo jornalismo para evitar confronto de interesses entre as partes envolvidas (anunciantes e leitores). 
os pontos nevrálgicos do tema em questão. Sua aplicação levaria o entrevistador a descobrir elementos suficientemente relevantes para realizar uma interpretação consistente e bem inteligível sobre o tema. O outro diz respeito à forma como o historiador Charles-André Julien narra o episódio, por ele presenciado, do conflito do Magreb em 1952. Lacouture (1995, p.237) salienta que, diante da torrente de interpretações e dubiedade das informações, Julien "move-se com uma mestria implacável, iluminando com seu imenso conhecimento do passado os frutos da sua enquete do presente".

Lacouture aceita a aproximação das duas áreas, mas aponta ressalvas que não podem ser ignoradas. Os fatos, tanto na história como no jornalismo, envolvem interesses, têm desdobramentos, implicações, provavelmente manipulam informações, ou seja, a investigação teria bons resultados na medida em que se consultasse o maior número de fontes possíveis e se conhecesse em profundidade o contexto no qual o fato ocorre. Esses elementos ajudariam na interpretação e minimizariam erros passíveis de ser cometidos pelas duas profissões.

Se escrever e descrever um fato repercute tanto na sociedade, a ponto de interferir na formação da sociabilidade, resta agora entrar, de maneira mais detalhada, na compreensão do universo no qual se inserem o jornal e o jornalismo.

Maurice Mouillaud talvez seja um dos pesquisadores que mais influenciaram a formação dos jornalistas brasileiros por acolher, na França, professores que tiveram e têm papel de destaque no âmbito da pós-graduação em Comunicação no Brasil, em centros como Brasília, Minas Gerais e Rio Grande do Sul. Para nós, interessa conhecer suas ideias, pois esse jornalista manteve uma relação intensa com os historiadores da denominada História Nova. Muitos de seus pontos de vista acabaram sendo incorporados nas abordagens e interpretações de fatos em nossos trabalhos. Por essa razão, vemos componentes relevantes na obra desse jornalista e professor francês, preocupado em encontrar uma explicação para o papel do jornalismo na contemporaneidade.

Para Mouillaud, no jornal se entrecruzam episódios selecionados pelos jornalistas, além de se espelharem as circunstâncias estruturais 
que demarcam o momento no qual ocorrem os fatos. Sua interpretação, que nunca está solta no espaço e no tempo, obedece a essa lógica implícita na elaboração e na concepção do que é o próprio de cada jornal. ${ }^{9}$ Mouillaud aponta o surgimento das agências de notícias, no século XIX, como responsáveis pela transformação do jornalismo e por sua configuração mais recente. Efetivamente, naquele momento, o surgimento das agências de notícias e a consequente valorização da informação deram outro sentido ao jornal e aos fatos por ele publicados. Se, antes, existiam inúmeras páginas nas quais era possível encontrar as narrativas literárias, com a valorização da informação esse espaço passou a ter outra configuração. As páginas cinzentas recheadas de longas narrativas abriram espaço para textos curtos, concisos, onde primava a quantidade e os fatos apareciam isolados, sem nexo ou ligação entre eles. De preferência, as matérias publicadas deveriam ser ilustradas com fotos.

Não se incorporava, apenas, uma mudança na forma de apresentar o jornal para o leitor. A alteração ocorrida escondia uma série de armadilhas nem sempre perceptíveis pelos próprios jornalistas. A mais evidente residia na questão do percurso utilizado entre o fato e sua publicação. Incide, nessa trajetória, uma longa cadeia de transformações em que os jornais, no final das contas, tal como lembra Mouillaud, publicam um real já domesticado. Essa colocação nos faz supor que a narrativa literária, anterior ao surgimento da valorização do fato, teria a função de despertar a imaginação, de fugir da premência do tempo, de permitir debates e não viver do furo, da novidade ou do extraordinário. Em algumas ocasiões, tais debates serviam de confrontos responsáveis por profundas transformações políticas e culturais. De qualquer forma, Mouillaud (in

9 Por esse motivo, considera de suma importância que se realize, antes de iniciar qualquer julgamento ou apreciação do que cada jornal publica, a descrição do grupo, dos empresários, da linha editorial, em suma, do que compõe a direção do jornal. De posse dessas informações, muitos dos posicionamentos assumidos se explicariam e se entenderiam melhor do que se não se realizasse inicialmente esse trabalho. 
Mouillaud \& Porto, 2002, p.51) sustenta que na contemporaneidade o jornal é

Apenas um operador entre um conjunto de operadores sóciosimbólicos, sendo, aparentemente, apenas o último: porque o sentido que leva aos leitores, estes, por sua vez, remanejam-no a partir de seu próprio campo mental e recolocam-no em circulação no ambiente cultural.

São observações importantes as contidas na passagem anterior, em parte, por considerar os acontecimentos que chegavam aos leitores já mediados, e estes, por sua vez, tal como já havia sugerido Thompson, ainda os reinterpretam em função de seu ambiente cultural. Por isso, Mouillaud defende a ideia de que a informação não é apenas o transporte de um fato, e sim um ciclo ininterrupto de informações. Nesse ciclo em que se tornam públicos os fatos, intervêm vários personagens, dentre os quais sobressaem os promotores e os elaboradores do acontecimento. Ambos carregam os interesses implícitos ou explícitos que fazem que filtrem dados, conteúdos e circunstâncias sob as quais o fato se desenvolve. Essa seria a razão pela qual um episódio se torna conhecido e outro não. Os dois existem, mas as escolhas determinam que se agreguem valores a alguns em prejuízo de outros. Dessa maneira, os fatos levam na sua publicação uma dose de sentido pessoal do jornalista ou da agência de onde foram extraídos.

Para evidenciar esse processo, Mouillaud usa um recurso ilustrador. Ele compara o processamento da informação na forma dialógica e na comunicacional. Na primeira, prevalece a retórica orgânica na qual se constata a presença do comunicador e do receptor. A ação se processa num espaço e tempo determinados, e, via de regra, almejam-se a persuasão e o convencimento sem que haja uma preocupação em divulgar fatos novos. Na segunda, ocorre a inversão do processo, ou seja, não há a presença dos protagonistas, passa-se por uma seleção, descontextualiza-se, visando a divulgar fatos ou acontecimentos reconstruídos. Assim, acaba com a organicidade e estabelece a frag- 
mentação e brevidade na sua narrativa. Mouillaud (in Mouillaud \& Porto, 2002, p.58) mostra, de maneira bastante enfática, o que se passou com os processos comunicacionais com adoção de matérias vindas das agências de notícias:

De fato, o despacho de agência resulta de um desvio. Expedir uma informação é desviar a fala de seu destino primeiro, onde possuía um valor de uso, para enviá-la a receptores para os quais não estava destinada. Uma segunda comunicação acrescenta-se à comunicação primeira.

A experiência da forma dialógica de comunicação não se pode reproduzir nos meios de comunicação pelas características delimitadoras de espaço e tempo atribuídas por Mouillaud ao acontecimento, que, no processo comunicacional, é móvel, circula, nunca aparece de maneira estática ou definida. Desse modo, ao não retratar a totalidade, torna-se parcial, separado do seu contexto, uma vez que prevalecia a tentativa de levá-lo para o maior número de pessoas possível. Nesse momento, lembra Mouillaud, a informação se converte em mercadoria, tornando-se, em algumas ocasiões, irreconhecível em razão das transformações operadas na sua divulgação. $\mathrm{O}$ acontecimento, tal como aparece divulgado nos meios de comunicação, expressa, apenas, a parte emergente de um processo de informação que começou bem antes, em outro espaço e em outro tempo. Assim, só resta, sustenta esse autor, ver e aceitar a pluralidade nos fatos que estudamos ou que nos chegam via meios de comunicação. Eles envolvem pessoas, interpretações, visões de cultura que os tornam plurais. O modo como são feitos os jornais impede que se crie uma unidade entre as diversas informações oferecidas.

Assim, os grandes acontecimentos são fragmentados de maneira dupla: na sua origem, por serem desassociados de uma experiência que permanece fora do contexto; na sua divulgação, por aparecerem inseridos, sem o devido destaque, entre outras notícias, correndo o risco, inclusive, de se vulgarizar. Uma das restrições com as quais o jornal trabalha é com o sentimento de pertença a um lugar determi- 
nado. Por isso, na sua elaboração, a maneira de abordar as questões locais ou nacionais recebe tratamento diferenciado em relação às internacionais, por exemplo. ${ }^{10}$ Mesmo assim, não se pode ignorar que o jornal coloca o leitor diante de acontecimentos que provocam reações nos receptores nem que sejam, apenas, para se comparar com os fatos aos quais tem acesso. A tendência, em virtude dessa aparente curiosidade do leitor, seria apresentar o espetacular, o curioso, ou seja, o que é do interesse do leitor. Assim, o receptor reconstrói seu mundo e, de alguma maneira, dialoga com seu entorno mais próximo.

Mesmo assim, Mouillaud enfatiza considerações bastante relevantes, para nosso propósito, principalmente ao tentar estabelecer pontes entre o fato e sua repercussão social num tempo e espaço específicos. Nesse vasto universo de informações descontextualizadas e desconexas, ocorre uma unificação e interligação entre elas: sua atualidade. Esse seria o ponto de convergência dos acontecimentos. Mas afirmar que só existe informação atual nos meios de comunicação implica aceitar a impossibilidade de reconstituição dos fatos, bem como a incapacidade de atribuir-lhes um significado. Como o próprio Mouillaud sugere, o presente tem uma tendência destruidora, pois nada mais é do que um "desencadeamento dele mesmo, num nascer diário".

Dessa maneira, o presente e o presenteísmo carregam, na opinião de Mouillaud, uma forma de destruição constante que morre no dia da sua publicação, mas que se renova no dia seguinte, desencadeando um processo contínuo de nascimento diário. Para fugir dessa armadilha vigente nos meios de comunicação, notadamente nas práticas do jornalismo, Mouillaud se remete ao processo clássico de comunicação: emissor, meio, receptor e suas possíveis inter-relações. Ora, se a comunicação envolve uma representação na qual o receptor identifica e reconstitui seu mundo no diálogo com os produtos da

10 Apenas para ilustrar, basta verificar o número de assinantes de jornais numa cidade média, do porte de Bauru. De longe o Jornal da Cidade, com quase 25 mil assinaturas, é o mais vendido. Já a Folha de S.Paulo e O Estado de S. Paulo mal chegam a 12 mil, isso somando o número de assinantes dos dois jornais. 
mídia, a atualidade e o presente passam a ter um sentido por mostrar fatos capazes de interferir na elaboração do futuro e remeter às expectativas do passado do receptor. Justamente o atual, por ser atual, no momento em que nos encontramos, tem que ter um sentido. Assim, ele se aproxima das ideias de autores descritos nas páginas anteriores, ao assumir uma perspectiva que acredita na possibilidade de interação no contexto social, como fizera Thompson, por exemplo.

$\mathrm{O}$ acontecimento repercute em dois sentidos. Por um lado, apresenta situações visando à construção de um futuro, mas, por outro, reconstitui e insere sua descrição numa atualidade de acontecimentos passados dos quais reatualiza seu significado. Nesse espaço, interferem as experiências individuais do leitor, na medida em que dialoga com o meio no qual se encontra, confrontando sua cosmovisão e experiência com esse estímulo vindo do jornal. Não existe uma temporalidade só nos jornais. Cada acontecimento se consolida dentro de cada temporalidade, e, embora a mídia privilegie o presente, fatos noticiados demandam uma explicação diferenciada se comparados com outros menos relevantes no relacionamento com a sociedade. ${ }^{11}$

Na tentativa de definir o que seria fato histórico e fato jornalístico, Héctor Borrat (in Fontcuberta \& Borrat, 2006, p.313-47) apresenta algumas semelhanças dignas de uma consideração prévia à exposição da proposta de Mouillaud, a fim de superar essa aparente dicotomia. Borrat, servindo-se das afirmações de Paul Veyne (1983), sugere que a escrita da história nada mais é do que um conjunto de "versões de uma interação ou uma rede de interações", coincidindo com boa parte das considerações de Mouillaud. Afinal, indaga Borrat, onde surge a narrativa na história? Os acontecimentos históricos se estruturam por eles mesmos ou são os historiadores quem os colocam em ordem cronológica e de sentido ${ }^{12} \mathrm{Na}$ tentativa de aproximação entre o ofício

11 Basta olhar as páginas dos jornais para identificar formas, na atualidade, de contextualizar os fatos. Elaboram-se quadros explicativos nos quais se relata como determinado acontecimento se originou, quem está envolvido, passos dados até esse momento etc. - tudo para que o leitor não se perca e não abandone a leitura.

12 Essas questões emanam da obra de Veyne (1983). 
dos historiadores e o dos jornalistas, Borrat sustenta a ideia de que, no jornalismo, a narrativa se constrói tentando ser o mais fiel possível aos fatos, embora o jornalista saiba das limitações desse esforço. Já na história, a construção da narrativa cabe ao historiador, pois os acontecimentos não têm sentido por eles mesmos. Tanto os historiadores como os jornalistas constroem uma reconstituição parcial, na qual se procura atribuir um significado e um sentido para o fato descrito. Assim, ambos se distanciam dos relatos baseados na ficção, por trabalharem com preocupações e procedimentos que interferem e repercutem no âmbito social.

Borrat (in Fontcuberta \& Borrat, 2006, p.330) cita alguns procedimentos nos quais historiadores e jornalistas procedem de maneira semelhante. Na construção da narrativa, historiadores e jornalistas descrevem os eventos partindo de rupturas temporais; os personagens se inserem num contexto, não se personalizam os acontecimentos; os acontecimentos devem ser contextualizados; o cenário dos acontecimentos deve ser ampliado para dar força ao tema tratado; por meio de perguntas e respostas se elabora uma sequência temporal; a pretensão consiste em traduzir para o público a trama estudada sem tentar influenciar com suas opiniões, apenas mostrando credibilidade na sua exposição; a narrativa sempre é provisória, pois, à medida que novos fatos aparecem, o sentido tem que ser revisto; e, finalmente, historiadores e jornalistas almejam chegar a uma verdade.

Mouillaud, seguindo as pegadas de Nora (1995), não vê problema nenhum em relacionar a atualidade e a história. A ideia mais forte usada por Mouillaud se relaciona com o conceito de história vivida na qual o passado não pode ser visto como alienado do presente em que nos encontramos. Na história vivida, o passado remete a um horizonte que é "um passado que vive" (Mouillaud \& Porto, 2002, p.79). Desse ponto de vista, convém lembrar que cada fato histórico estudado e analisado também teve seu presente e repercutiu no momento em que ocorria. Como todos os fatos interessam para dar um sentido à atualidade, a operação histórica desenvolvida pelo historiador passa pela decodificação dos sentidos atribuídos ao acontecimento em questão. Nessa operação investigativa, o ideal 
seria descobrir o valor dado, em cada época, aos fatos considerados importantes e desencadeadores de um processo que desemboca na atualidade.

Cada episódio tem seu passado, mas carrega também seu futuro, por gerar consequências de repercussão social. Todas as revisões e reinterpretações, de alguma maneira, se servem de novos acontecimentos, de novos documentos, de novos depoimentos ou de outros instrumentos que, quando inseridos numa trajetória, adquirem um sentido com força suficiente para alterar interpretações anteriormente estabelecidas. Por esses motivos, tanto o jornalismo como a história, afirma Mouillaud, deveriam se aproximar mais e dialogar sem que isso implique mudanças de percursos peculiares a cada área.

Por ter uma narrativa construída no momento e por todos os outros itens apontados anteriormente, Mouillaud sugere que a leitura dos acontecimentos da mídia seja feita pelo viés negativo, ou seja, não como algo que fornece apenas informação, mas que a oculta, notadamente por não apresentar o fato na sua relação existente entre ele e as fontes. Sabe-se que qualquer sistema tende a ocultar seu funcionamento. Se a cada dia a mídia faz e refaz o acontecimento, nada melhor do que duvidar da informação recebida. Esses seriam, na visão de Mouillaud, alguns dos pontos para se refletir na hora de considerar e estudar os episódios veiculados na mídia.

Pelo exposto até agora, podemos afirmar que as semelhanças e convergências entre a história e o jornalismo na abordagem dos fatos se encontram na atualidade e na repercussão social. Partimos do pressuposto de que, nessa aproximação, prevalece a procura de um ideal tanto para o jornalista como para o historiador. O jornalista tem como missão principal esforçar-se para reconstituir e explicar ao seu leitor a sequência e os laços que se vinculam às notícias apresentadas cotidianamente. Dessa maneira, a informação adquire um sentido mesmo que ela seja desmontada no dia seguinte pela revelação imposta por outros acontecimentos. Já o historiador realiza processo semelhante na medida em que tenta reconstituir por que caminhos o fato chegou ao momento do presente. O historiador, nessa evolução, analisa as estruturas que ocasionaram tal desfecho com relação ao 
tema que estuda. Chegamos, dessa maneira, a um ponto relevante relacionado com as abordagens e interpretações que a história faz dos acontecimentos mais próximos do historiador, item que se pretende estudar a seguir, privilegiando as correntes da história preocupadas com a temática mais contemporânea. 


\title{
3 \\ CoRRENTES HISTÓRICAS CONTEMPORÂNEAS
}

\author{
"O homem nãoé mais do que a série dos seus \\ atos." (Hegel)
}

Um gênero da história. Dessa maneira será entendida neste livro a história do tempo presente. A opção feita procura responder aos inúmeros questionamentos, dúvidas e desconfianças envolvidos no seu reconhecimento como ciência por parte de alguns historiadores. Essa visão, ao mesmo tempo, aceita que a história possui limitações, mas não nega sua relevância. Como veremos nas páginas seguintes, discrepâncias e afinidades não faltam quando se tenta estabelecer a metodologia, o objeto e o campo de atuação dentro dessa concepção da história.

Na procura pelas origens da história do tempo presente, Chauveau \& Tétard (1999) apontam o final da década de 1970 como o momento no qual se consolidou essa nova visão da história. As origens mais próximas, na caminhada para ser aceita entre os historiadores, se encontrariam em Marc Bloch e Lucien Febvre quando se remetiam, nas suas obras, à necessidade de se conhecer o presente para poder interpretar o passado. ${ }^{1}$ Mas, como todo começo, ainda na década de

1 Entre as décadas de 1970 e 1980, emerge uma grande pluralidade de denominações e concepções relacionadas com a história. Neste trabalho, em razão de 
1970, pouco se produzia para sustentar a noção da história do tempo presente. Não houve uma grande obra de referência capaz de servir de paradigma para amparar essa interpretação da história. Dois artigos sobressaíram nessa evolução, ambos copilados na obra de Jacques Le Goff e Pierre Nora, "O retorno do fato", do próprio Nora (1995), e "A história imediata" de Jean Lacouture (1995). Mesmo assim, esses autores reconhecem que a história do tempo presente seria feita de maneira mais competente por sociólogos, cientistas políticos e alguns bons jornalistas.

Apontar o conteúdo dessas contribuições iniciais pode ser bastante esclarecedor para compreender por que essa maneira de ver a história ganhou corpo entre os historiadores. Pierre Nora (1995) parte, para explicar a necessidade de se ter uma história do presente, dos limites contidos no conceito de história contemporânea, tal como entendida até então. A periodização tradicional incluía, nesse conceito, um espaço de tempo longo, iniciado na Revolução Francesa e vigente até a década de 1970, momento em que ele escreve. Assim, essa conceituação, sustenta Nora, carregava uma armadilha e uma contradição. A armadilha se encontrava na sua inserção na periodização proposta pelos positivistas, inútil para explicar alguns acontecimentos recentes nesse longo espaço de tempo. A contradição emanava do item anterior. Afinal, poderiam ser colocados, na mesma continuidade de tempo, fatos tão antagônicos e tão marcantes como as duas guerras mundiais e a própria Revolução Francesa? Por essa razão, Nora (1995, p.180) relembra que

[...] a rapidez das comunicações e a penetração das economias modernas nas sociedades tradicionais, em resumo, tudo o que se costuma entender por "mundialização" assegurou uma mobilização geral das massas que, por trás do front dos acontecimentos, outrora repre-

sua finalidade, abordaremos a história do tempo presente, a história imediata e a história a debate. Todas essas definições exaltam o posicionamento de Bloch e Febvre ao defenderem a necessidade de se estudar o presente para interpretar o passado. Ainda verificamos que essas abordagens são as que mais se aproximam do campo do jornalismo, notadamente a história imediata e a história a debate. 
sentavam os civilizados da história. [...] essa vasta democratização da história, que fornece ao presente sua especificidade, possui sua lógica e suas leis: uma delas - a única que aqui desejamos isolar -é que a atualidade, essa circulação generalizada da percepção histórica, culmina num novo fenômeno: o acontecimento.

As observações anteriores se revestem de grande significado para o presente trabalho. Ao reconhecer a penetração de novos agentes nas sociedades tradicionais, Nora adianta alguns dos elementos principais, apontados nas décadas seguintes, como os responsáveis pelas mudanças sociais nas sociedades globalizadas. O acontecimento rápido, expresso por Nora, antecipava um dos eixos nos quais se assenta a atualidade: a velocidade. Ainda destaca a revalorização que passa a ter o acontecimento nesse mundo veloz e em transformação. Dessa maneira, Nora realiza uma dura crítica ao pensamento positivista, notadamente aquele que defende que a história nasce quando o fato já aconteceu, motivo pelo qual seu campo de atuação e preocupação fundamental seria unicamente o passado.

Como se pensar no passado se o presente está permeado por inúmeros acontecimentos relacionados a uma classificação incapaz de explicá-los? Nora não aceita tal visão, embora se aproveite da metodologia de trabalho defendida pelos positivistas para justificar outras visões da história. Se o positivismo valoriza o acontecimento passado e acabado para criar um sentido, por que não usar esse mesmo procedimento com os fatos mais recentes? Tal questionamento implica a valorização e a preocupação com o acontecimento recente, mas sem perder o rigor e o procedimento já conhecido pela história na elaboração de outras grandes narrativas.

Nora aceita a influência decisiva dos mass media como fatores de destaque na valorização dos fatos do presente. Tal abordagem coincide com a dos pensadores da Escola de Frankfurt, que valorizam os meios de comunicação de massa, nem sempre positivamente, na hora de definir a sociabilidade contemporânea. Uma coisa é a sociedade estar exposta cada vez mais aos meios de comunicação e outra é aceitar que os meios determinam comportamentos ou padronizam 
atitudes. Tal anuência pressupõe a passividade social e a reação uniformizada nas respostas aos estímulos propostos pelos mass media. Hoje, sabemos que tal postura não corresponde à verdade, pois nem todas as camadas sociais ficam expostas constantemente aos meios nem se encontram pesquisas ou dados suficientemente sólidos para realizar tal afirmação. Nora aceita a relevância dos fatos tornados públicos pelos meios de comunicação. Vai mais longe e reconhece a dependência das notícias para se estar informado. Essa dependência dos meios, seguindo o raciocínio de Nora (1995, p.180-1) provocou mudanças, pois

[... ] a partir da condição de que o presente, dominado pela tirania do acontecimento, ficou proibido de residir na história, ficou entendido que a história seria construída sobre o acontecimento. [...] É aos mass media que se deve o reaparecimento do monopólio da história. De agora em diante esse monopólio lhes pertence. Nas nossas sociedades contemporâneas é por intermédio deles e somente por eles que o acontecimento marca a sua presença e não nos pode evitar.

Os meios de comunicação se tornaram, segundo Nora, a condição da existência dos fatos. Isso não significa que os episódios mais relevantes se encontrem sempre neles. Acontece que, sem a divulgação na mídia, raramente tornam-se conhecidos, ficando a impressão de nunca existiram. As afinidades entre o acontecimento e os veículos de comunicação de massa são tão intensas que pareciam, de acordo com ele, inseparáveis. Nora alerta para a parcialidade dos meios na representação dos fatos. Ao noticiar uma guerra, eles divulgam parte dela, não a sua totalidade. Assim, por exemplo, uma cena de atrocidades não representa a totalidade do acontecimento. Entretanto, para a maioria da sociedade, essas imagens acabam prevalecendo, perdendo-se, dessa forma, a possibilidade de criar um debate ou discussão relacionados a motivações, jogo de interesses, desdobramentos, implicações e demais fatores envolvidos no evento.

Dessa maneira, o sensacionalismo torna-se um dos elementos constitutivos da contemporaneidade e a sociedade passa a buscar 
nele o inusitado, o singular, o espetacular, o insólito, resultando num processo de desvirtuação dos fatos. ${ }^{2}$ Ainda, na explanação realizada pelo autor, a junção dessa característica com a modernização e a rapidez oferecida pelos meios fez que o acontecimento chegasse para o historiador de uma maneira nova e diferente daquela mais tradicional, tal como era vista pelos positivistas. Efetivamente, na contemporaneidade, os fatos chegam ao conhecimento do historiador antes de se saber o desfecho final.

Nora, diante dessa situação, sugere alguns cuidados para quem estuda os fatos do presente. Alerta, enfaticamente, para o caráter emotivo gerado pelos meios de comunicação. Efetivamente, a exposição de determinados fatos, descontextualizados e recortados, desperta a emotividade e não a racionalidade ou, como ele afirma, "é bom se precaver, pois a realidade propõe, mas é o imaginário que dispõe". Lembra que para o historiador, acostumado a trabalhar com fatos enquadrados dentro de uma racionalidade social, política, cultural e econômica, ocorre, sim, um problema de interpretação do acontecimento vindo dos meios de comunicação. Não se pode deixar levar pelo extraordinário, pelo descontextualizado, sob o risco de se aproximar do mundo do imaginário, do irreal. Ainda devem ser lembrados os filtros aplicados no próprio jornal desde a chegada da notícia até sua publicação.

As colocações anteriores alertam o historiador, pois "as massas” vão procurar nesses acontecimentos valores ou situações nas quais reconheçam alguns fatos ocorridos com elas "como podem ser assuntos ligados a seus dramas, seus mistérios, sua estranheza, sua poesia, sua tragicomicidade, seu poder de compreensão ou bem valores com os quais se identifique como o luxo, grandiosidade e gratuidade" (ibidem, p.184). Ocorre uma transformação/inversão dos valores na sociedade, pois, se a razão histórica buscava um sen-

2 Essa transformação no jornalismo ficou conhecida pela busca da novidade, do furo, do que chamasse a atenção do público. Assim, por exemplo, informar que o homem mordeu o cachorro seria uma notícia válida. Já o contrário não interessava, por ser o habitual, aquilo com que estamos acostumados. 
tido nos acontecimentos, na sociedade dos meios de comunicação de massas nem sempre se vê a totalidade, razão pela qual a veiculação dos fatos sofre uma releitura nem sempre desejável e muito menos com uma finalidade clara e definida. O espaço para inserir distorções e manipulações nos meios de comunicação é amplo. Nada impede que cheguem a ser apresentados de maneira totalmente contrária para atender a particularidades e situações que beneficiariam determinados grupos ou pessoas.

O acontecimento, por causa da rapidez das transmissões, ganha dimensões nunca pensadas até esse momento. Os prazos a cada dia são encurtados, abrindo-se as possibilidades das incertezas e das dúvidas e, principalmente, o desenvolvimento da tragédia considerada como geradora da emotividade das massas. Por essa razão, Nora sugere que a história contemporânea poderia iniciar-se pela frase "eu aí estava...", o perigo reside, justamente, na carga afetiva de tal constatação e nos desdobramentos que gera. $\mathrm{O}$ acontecimento, ao se tornar do domínio das massas, pelo seu caráter emotivo e afetivo, perde sua objetividade.

A massificação, alerta Nora, teoricamente traria repercussões pouco desejáveis para a sociedade. Com ela se perde a objetividade e se submerge num oceano representado por uma sociedade de massas, na qual os compromissos individuais encontram-se desvirtuados. A rigor, sugere Nora, tudo seria de todos, mas ninguém se sentiria tocado na sua responsabilidade de cidadão. A participação efetiva perde espaço, tornando-se um procedimento marcado por fortes doses de alienação, impotência, distanciamento e falta de autonomia. ${ }^{3}$ Com essa impalpável realidade da vida contemporânea, que se chama opinião e que se propaga via publicidade, existe um risco de se chegar ao autoritarismo pela adoção do espetáculo e pela falta de criticidade e de participação.

Nora (1995, p.186) mostra um cenário bastante negativo ao perceber que

3 Novamente, vemos nessa concepção de Nora (1995) a influência do pessimismo dos autores ligados à Escola de Frankfurt. 
[... ] informação perdeu sua neutralidade de órgão de simples transmissão. Ela não era por natureza, apesar das distorções superiores, senão uma correia de transmissão, um ponto de passagem obrigatório. $\mathrm{O}$ acontecimento era emitido, transmitido e recebido. [...] ora, considerado globalmente, o sistema informativo dos media fabrica o ininteligível. Bombardeia-nos como um saber interrogativo, sem núcleo, sem sentido.

Por trás do espetáculo contemporâneo proporcionado pelo acontecimento, ocultam-se tendências destinadas a impedir qualquer transformação social. Seria correto afirmar que no processo de mudança acontece uma guerra de informações destinada a minimizar a relevância do acontecimento que representa a ruptura necessária para pôr em xeque o equilíbrio no qual a sociedade - objeto de transformação - assentava os valores e normas de funcionamento. Nora defende que, na contemporaneidade, o caráter revolucionário se perde. $\mathrm{O}$ acontecimento chega através de um sistema de informação que não informa, e, consequentemente, acontece a integração num sistema mais conservador proposto pelos próprios meios de comunicação. ${ }^{4}$

Segundo Nora, nossas sociedades contemporâneas se caracterizariam por esse "estado de superinformação perpétua e de subinformação crônica”. Em razão dessa situação, o historiador do presente teria a missão de separar, nas suas narrativas, o real do imaginário, o espetacular do que possa ser importante, para elaborar textos suficientemente sólidos e consistentes impregnados, sim, de fatos importantes para reconstituir a realidade. Dito de outra forma, Nora indica um caminho interessante para analisar os fatos mais contemporâneos. Eles deveriam ser inseridos dentro de suas contradições sociais, evitando-se, dessa maneira, que caiam num vazio sem sen-

4 Nora (1995) oferece um exemplo bastante ilustrativo de como os meios de comunicação podem não despertar nenhuma preocupação social. Na antiga ex-URSS, as notícias dos jornais se centravam na transcrição de notícias do partido, datas de aniversários, descrição de festas, realizações, ou seja, sem grande valor para as pessoas que permaneciam anestesiadas com essas informações. 
tido, onde podem chamar a atenção, apenas, pela espetacularização e não por seu significado social. O acontecimento, na visão de Nora, "testemunha menos pelo que traduz do que pelo que revela, menos pelo que é do que pelo que prova”. Ele seria um espelho da sociedade, uma abertura para entender as relações sociais, inclusive para questionar a ordem estabelecida e identificar as novas forças emergentes na tentativa de mudança.

Assim, completa Nora, o imediato torna a interpretação de um acontecimento mais fácil e mais difícil. Mais fácil porque choca, chama a atenção e desperta interesse. Mais difícil porque se manifesta na sua totalidade na hora em que ocorre e ainda não se sabe que rumo pode tomar por não estar acabado. Cada acontecimento é originado por diversas causas provenientes de diversos lugares, razão pela qual o historiador do fato recente deve saber cruzar os elementos que o compõem e determinam. Tal procedimento não representa nenhuma novidade, pois é isso que as concepções anteriores de história já vinham sugerindo. Por isso, sugere descobrir a semelhança de fatores existentes, entre o acontecimento recente e o passado, como elemento-chave para que o historiador possa expor determinados desdobramentos dos episódios estudados. Adotar a história do presente não implica, de maneira alguma, descontextualizar, inovar na metodologia ou adotar novos objetos a serem pesquisados. Tal como Nora sugere, abraçar a história do presente implica assumir a função crítica e o exercício metódico e decodificador do historiador, contextualizando, cruzando informações e apresentando a trama dos acontecimentos sempre com uma finalidade clara: aumento da consciência social.

As contribuições de Nora, em 1974, data na qual publica o texto preocupado com o tema do fato, sobressaem por vários motivos, dentre os quais o que mais nos interessa refere-se à ligação do acontecimento com a mídia e aos perigos que tal aproximação implica. Os desdobramentos dessas reflexões colocariam em cena o ponto de vista de François Bédarida (1996), apontado como um dos primeiros historiadores preocupados com a sistematização da história do tempo presente, a elaboração do seu campo de atuação e a sistema- 
tização da relevância da volta do acontecimento tal como proposto por Nora.

A intensa movimentação de Bédarida resultou na criação, em 1978, na França, no Instituto de História do Tempo Presente (IHTP). Nele, esse autor vislumbrava uma oportunidade para definir suas peculiaridades e se desvencilhar dos entraves encontrados na história imediata e na história contemporânea na definição do tempo presente. Na primeira, esse autor via a falta de cientificidade nas obras relacionadas com os temas propostos, notadamente, na falta de uma heurística entre os termos passado/presente. A rigor, não se definia com clareza nem um nem outro. Já na segunda, Bédarida apontava dificuldades na hora de se realizar o enquadramento de certos temas nesse conceito, questão já apontada por Nora. O fato de aceitar a Revolução Francesa (1789) como o marco inicial do período contemporâneo resultava em dificuldades para explicar, por exemplo, como as duas guerras mundiais se inseriam dentro da sequência da periodicidade inaugurada pela Revolução Francesa.

Bédarida enquadra a temporalidade da história do tempo presente na perspectiva do tempo histórico, ou seja, na relação entre passado, presente e futuro, e na periodização emanada de um fato. ${ }^{5}$ Não podemos falar do passado sem levar em consideração o presente, pois o limite do passado se encontra no limiar do que está se tornando futuro, ou seja, o inédito. As fronteiras do passado seriam mais nebulosas, difusas e limitadas, como acontece com o tempo da história vivida. Ele reconhece a existência de certa flexibilidade nessa concepção embora sugira a necessidade de se apresentar a conjuntura à qual se faz referência, assunto esse já destacado por Nora, tal como vimos anteriormente. Advoga, desse modo, uma função social da história e dos historiadores inseridos no debate da interpretação da contemporaneidade. Encontra duas objeções na tentativa de con-

5 Novamente, aqui, encontramos uma remissão às considerações de Bloch e Febvre relacionadas à necessidade de se conhecer o presente para interpretar o passado, procedimento este também usado por Nora na justificativa da sua opção. 
solidar a história do tempo presente: a falta de um distanciamento para ganhar objetividade na análise dos acontecimentos e a ausência ou superabundância de fontes para alguns temas, dificultando sua seleção para o historiador na hora de tecer suas considerações. A soma desses dois problemas leva ao ponto central apontado por Bédarida como problemático na adoção da história do tempo presente.

Tal problema se enquadra na impossibilidade de se abordar um tempo do qual não se conhece o resultado do tema estudado. Os rumos dos fatos selecionados pelo historiador do tempo presente surpreendem. O desconhecimento de todos os componentes envolvidos no objeto estudado pode alterar o rumo dos acontecimentos de maneira não prevista. Alguns casos concretos explicariam tal problemática. Apenas para ilustrar: quem apostava na reeleição de Lula, em 2006, em pleno auge do escândalo do mensalão envolvendo o Partido dos Trabalhadores, partido esse do presidente? Para quem vivenciou essa situação, fica claro o alerta feito por Bédarida quando lembra a imprevisibilidade de alguns acontecimentos ou situações que podem apresentar trajetórias inconcebíveis no calor dos acontecimentos.

Para tentar superar esse tipo de situação, ele sugere que o historiador mantenha a isenção política, acredite em alguns princípios, como no valor da liberdade, e use e abuse dos exemplos do passado, já consolidados, para interpretar o presente. Assim, sabe-se que um regime autoritário dificilmente terá sucesso nas suas políticas sem ferir alguns princípios inerentes à liberdade ou à democracia política e social. Nessa situação, ao avaliar o tempo presente, as experiências do passado ajudam no estabelecimento de considerações do desfecho do modelo estudado, facilitando o trabalho do historiador. Ou seja, fazer história do tempo presente não isenta o conhecimento ou a consideração do passado. Abre, assim, as possibilidades de diálogo com outras correntes e vertentes da história, uma vez que aparecem como bases de conhecimento suficientemente fortes para estabelecer paralelismos e reconhecer semelhanças dos sistemas abordados.

As fontes da história do tempo presente recebem a atenção nas colocações de Bédarida, principalmente as relacionadas com a his- 
tória oral e os depoimentos provenientes de sua aplicação. O que se coloca em xeque é o papel da memória e os resultados obtidos na adoção dessa maneira de realizar as pesquisas, pois ocorre, segundo Bédarida, um jogo duplo na medida em que o entrevistador (o historiador) concretiza essa prática. Por um lado, o entrevistado se esforçará para convencer o entrevistador da veracidade de sua versão, enquanto o entrevistador sabe que essa é, apenas, uma versão, passível de críticas e de outras verificações, portanto não pode ser aceita como uma verdade definitiva. Por outro lado, vale a pena destacar que a pessoa entrevistada elabora um relato sobre o que vivenciou ou ouviu. Como narrativa, há uma transmissão de informações nas quais entram elementos subjetivos incrementados pelo entrevistado. Bédarida (1996, p.9) sustenta que

[...] a história se fundamenta sobre a idéia de que existe uma realidade exterior no mundo que é suscetível de ser convertida em inteligível. Tal realidade detém um grau de autonomia que é a base do conhecimento do passado. Essa realidade é a que apresenta o signo da alteridade. O historiador não é um criador de ilusões.

Bédarida reconhece a impossibilidade de se atingir precisão absoluta por parte dos historiadores, mas isso não impede que se procure a objetividade, a verdade e a exterioridade do real. Mesmo aceitando que nas suas elucidações se obtenham resultados parciais, a inquietação de lutar para conseguir se aproximar da fidelidade dos acontecimentos necessita prevalecer.

As considerações apresentadas por Bédarida tornaram-se objeto de análise nas obras posteriores à fundação do IHTP. Na década de 1980, o interesse pelas mentalidades, pelo político e pelo cultural mudou as preocupações dos historiadores, trazendo à tona temas e problemáticas que demandavam uma passagem pelo presente. Nessa evolução, a história política aparece como elo entre uma visão mais conservadora e tradicional da história e a adoção da história do tempo presente. A consolidação dessa nova maneira de entender a história se encontra, de acordo com Chauveau e Tétard (1999), no denomi- 
nado efeito de geração, entendido como a preocupação e vontade de explicar os últimos acontecimentos e seus impactos na sociedade. Essa ânsia por ter explicações fortaleceu a ideia de que a história pode ser, claro que com menor recuo e métodos particulares, o estudo do imediato. Bastante próxima dessa visão se consolidam a denominada história imediata e a história a debate, como veremos a seguir.

A história imediata compartilha com a história do tempo presente a constatação de que cada vez temos mais acontecimentos presenciados instantaneamente por milhões de pessoas. Diverge dela na hora de estipular uma fronteira limite para estudar os fatos. Na história do tempo presente se priorizam os fatos acabados. $\mathrm{Na}$ história imediata, os fatos estão ocorrendo, não tiveram um desfecho final. Em função dessa situação, a história imediata se alimenta com a proximidade temporal e material do autor em relação ao seu objeto de estudo. Além disso, a história imediata é próxima, participativa e rápida na sua execução, pois acaba sendo elaborada por alguém que presenciou e analisou o caso estudado. Essa peculiaridade tornou os mass media o veículo privilegiado para divulgar a história imediata, iniciando-se uma relação que passou da forma para o conteúdo, ou seja, os mass media acabariam divulgando resultados de historiadores identificados com a história imediata.

Três influências podem ser detectadas na construção da história imediata: o jornalismo, a própria história e a sociologia. Os métodos e as fórmulas empregados pelo jornalismo na hora de apurar as notícias (reportagem, entrevista, direito ao contraditório, uso de várias fontes...) sempre estiveram próximos dos acontecimentos, chegando, recentemente, até a transmitir ao vivo suas matérias. Ao proceder dessa forma, abriram caminhos para os partidários da história imediata. Os adeptos dessa interpretação aproveitaram esses procedimentos para entender suas explicações e dar sentido a elas. A história imediata encontra na sociologia interpretações de temas da contemporaneidade imediata, muitos deles tornados públicos pelos meios de comunicação. Assim, de alguma forma, abriram-se caminhos para justificar a cientificidade das interpretações dos historiadores, uma vez que os sociólogos já realizavam algo 
parecido. ${ }^{6}$ Interpretar o presente em função do passado, tal como proposto pela história do presente, não excluía o posicionamento e a análise do imediato, ao contrário, o historiador deveria realizar projeções para o futuro.

Jean Lacouture (1995, p.216) sustenta que a história imediata se elabora de maneira

próxima, participante, ao mesmo tempo rápida na execução e produzida por um autor ou uma testemunha vizinha do acontecimento, da decisão analisada - tal seria a operação histórica que queremos considerar aqui. ${ }^{7}$

Ela diminui o tempo de interpretação dos fatos, além de resgatar os atores dessa história, ou seja, alimenta-se com os arquivos vivos que são as pessoas envolvidas nos acontecimentos. De alguma forma, a proximidade determina a ligação afetiva do historiador com o assunto pesquisado, sem que isso implique a inexistência do trabalho de identificação, classificação, montagem e racionalização do objeto estudado. Por isso, Lacouture afirma que a opção pessoal serve de referência para as análises feitas pelo historiador. Alguém que participou do acontecimento valorizará o ponto de vista assumido no "calor da hora" enquanto procura minimizar seus opositores. ${ }^{8} \mathrm{Tal}$

6 Coincidentemente, no mesmo ano em que Lacouture (1995) publica seu texto defendendo a história imediata, o sociólogo Edgar Morin e os membros do Centre d'Études des Communications de Masse (Ephe, 6ํㅗ seção CNRS) começaram uma série de estudos sobre os acontecimentos da atualidade, inicialmente voltados para as análises de matérias de jornal e as reflexões feitas pelos jornalistas.

7 Apesar de ser aceito esse texto como um parâmetro para se definir a história imediata, nossa leitura diverge de outras, pois vemos que, em determinados momentos, história do presente e história imediata se remontam e se misturam nas observações de Lacouture (1995).

8 Os exemplos de Lacouture (1995) ilustram bem essa questão. Basta ler, por exemplo, as narrativas descritas por personagens envolvidos no acontecimento para aferir a parcialidade das versões, como fez Trotski ao descrever a história da Revolução Russa. De acordo com Lacouture, mesmo que essa obra tenha sido escrita anos depois de ter acabado o acontecimento, os fatos vistos, vividos e criados por Trotski dão um outro tom ao que aconteceu. É o autor tomando partido sobre determinados fatos. 
procedimento, salienta Lacouture, acontece em praticamente todos os procedimentos realizados pelos historiadores. Qualquer fonte usada é passível de conter essas marcas.

Um dos pontos mais emblemáticos com os quais se depara a história imediata diz respeito ao fato de o pesquisador não conhecer o desfecho dos acontecimentos. O historiador-repórter entra e aborda uma determinada situação, tendo que chegar a um fim, a um desenlace final. Entretanto, como o fato não acabou, podem acontecer desfechos inusitados e inimagináveis num determinado momento. Lacouture ilustra essa afirmação com um exemplo bastante convincente, ao questionar a rigidez de alguns historiadores que não aceitavam a possibilidade de um reatamento do diálogo entre Egito e Israel depois do conflito envolvendo esses países. Não obstante, a retomada das negociações aconteceu, servindo de alerta para o imediatista no sentido de que todas as possibilidades podem acontecer. Como ele mesmo sustenta: quem, no século VII, poderia anunciar que em menos de um século os árabes estariam em Poitiers?

Mas não conhecer o desfecho pode ser vantajoso. No momento em que o fato acontece, defende Lacouture, equalizam-se melhor as forças envolvidas, até porque as pessoas, agora atores, desejam defender, de todas as maneiras possíveis, seus pontos de vista. Já quando se conhece o desfecho do assunto estudado, corre-se o risco de menosprezar as fontes "perdedoras" por prevalecer a visão dos vencedores. $\mathrm{O}$ imediatista precisa ficar aberto a todas as possibilidades, o que não significa que concorde com tudo que vê ou escuta.

Poderá um historiador da colonização dar hoje, com toda sua ciência, sua honestidade, a segurança da sua documentação uma idéia da candura das ilusões coloniais no início da década de 1880? (Lacouture, 1995, p.225)

Com o desenvolvimento das tecnologias, as possibilidades de aumentar as fontes para a pesquisa da história do imediato cresceram consideravelmente. Contudo, Lacouture alerta sobre a necessidade 
que o historiador do imediato precisa ter para pôr ordem, delimitar, dominar e explicar esse amplo número de informações às quais tem acesso. Desnecessário lembrar que em muitas delas, sem dúvida, aparecerão inverdades, ideias falsas ou propagandas de determinadas pessoas e interesses.

Outra questão enfrentada pelo historiador do imediato reside na difícil situação com que terá que conviver caso chegue a promulgar situações contrárias às pessoas ou interesses envolvendo suas fontes. Muitas portas vão ser fechadas pela denúncia que realiza depois de publicar seus resultados, o que Lacouture ilustra da seguinte maneira: "o imediatista serra o galho em cima do qual trabalha". O historiador do imediato é um coletor de fatos e produtor de efeitos, razão pela qual, em determinados momentos, mantém precauções, sigilos até, em relação a seus informantes. Preservadas suas fontes, poderá obter informação privilegiada, fruto da confiança dos informantes. O historiador do imediato nunca deve se esquecer de que o mundo contemporâneo é menos permeável do que o do século XIX, o que dificulta o acesso a dados importantes.

Lacouture reconhece o aumento das informações e seu caráter mais plural, mas aceita que tal abundância não implica objetividade, ao contrário, a subjetividade emerge como um grande dilema da história do imediato. $\mathrm{O}$ historiador do imediato, igual a qualquer outro historiador em qualquer momento ou época, expressa suas crenças e o ambiente sociocultural no qual se encontra inserido nos resultados das suas investigações. Por essa razão, é aconselhável que o imediatista deixe claras suas inquietações na hora de desenvolver seu trabalho.

É se manifestando que ele se neutraliza, ou abre para si as portas da equidade. É assinalando os desvios da bússola que pode reconhecer-se imparcial. É progredindo mascarado que o pesquisador do imediato se afasta com mais segurança da operação histórica. O que constitui o valor de grandes obras imediatas como $O$ arquipélago de Gulag é a clareza das afirmações preliminares e a transparência do propósito. (ibidem, p.230) 
Feitas essas considerações, Lacouture explica como o historiador do imediato deve se relacionar com os fatos. O acontecimento provoca transformações estruturais e, para entendê-las, convém descrever o contexto no qual acontecem. Entretanto, recorda Lacouture, como muitas das informações provêm dos meios de comunicação, pode ocorrer a superdimensão de alguns fatos, gerando o que denomina de "acontecimento monstro". Tal procedimento, bastante usual nos meios de comunicação, geraria a ditadura do factual, tal como denominada pelos historiadores dos Annales. Ora, se todo fato é importante, sobredimensionar alguns resulta num processo de manipulação com repercussões sociais na medida em que outros ficam excluídos. Parece claro que, em função das finalidades pretendidas, manter o equilíbrio e envolver o maior número de informações na descrição dos episódios resulta numa atitude bastante aconselhável para não ser dominado pelo objeto da pesquisa. Ainda, seria aconselhável explicitar, claramente, as opções feitas na elaboração de seu relato.

Para evitar a deturpação das interpretações, impõe-se a interdisciplinaridade. Lacouture propõe, mesmo prevalecendo a interdisciplinaridade, não abandonar o rigor da ciência histórica. Usando sua capacidade de elaborar metáforas e realizar comparações, define o papel do historiador do imediato como alguém que se esforça para explicar "não as mudanças, muito menos o mudado, mas sim o mudar". O imediatista direciona seus esforços para compreender essa passagem existencial no desenvolver dos acontecimentos. Assim, abria-se o início dos anos 1990 com novas pretensões de estabelecer formas e abordagens mais próximas do contexto no qual vivia o historiador. Uma delas, a que mais nos chamou a atenção, diz respeito à denominada história a debate.

Essa história inicia publicamente suas atividades num congresso internacional, realizado na cidade de Santiago de Compostela, na Espanha, em 1993. Nele circularam textos de autores reconhecidos como Roger Chartier e de outros, ainda pouco expressivos, mas partícipes da ideia de que a maneira como tinha sido escrita e concebida a história, depois da Segunda Guerra Mundial, vivenciava uma crise manifesta nos constantes ataques sofridos notadamente aos aconteci- 
dos após a queda do Muro de Berlim, em 1989. Aceitam que, nesse espaço de tempo do século XX (desde a Segunda Guerra Mundial até a queda do Muro de Berlim), a história vivenciou paradigmas provenientes dos Annales, do marxismo e do estruturalismo. ${ }^{9}$ Porém, as transformações decorrentes dos desdobramentos do fim do socialismo real propiciaram uma crise generalizada nas ciências sociais à qual a história não ficaria imune. Essa crise se manifestou, ainda de acordo com esse grupo de historiadores, numa tripla dimensão:

1) Da história objetivista, economicista, quantitativista, estruturalista, que dá lugar nos anos 1970 a uma progressiva volta do sujeito, primeiro social (historiografia marxista anglo-americana), depois mental (história francesa das mentalidades) e por último tradicional (biografia, história política).

2) Da história total, abandonada como enfoque da investigação, proclamada como algo impossível de atingir, mas que é necessário manter como "horizonte utópico" dos historiadores, renunciando-se depois a ela no plano da teoria, ao mesmo tempo que - já nos anos 1980 - a história se desenvolve exatamente em sentido contrário: fragmentando-se até o infinito em temas, gêneros e métodos.

3) Da relação passado/presente/futuro, em que falhou, por exemplo, a sensibilidade do historiador para o feminismo e para a relação homem-meio ambiente, que, para a nova história, geográfica e econômica, reduzia-se ao estudo do domínio da natureza por meio do trabalho ou dos condicionamentos geográficos da sociedade. A hoje vigorosa história das mulheres (e o mesmo podemos dizer da história ecológica) desenvolveu-se, portanto, à margem dos Annales e do materialismo histórico, sobretudo em seus começos, e contra os hábitos pré-teóricos da persistente

9 Entendemos por paradigma o conjunto de compromissos compartilhados por uma comunidade científica dada: aqueles elementos teóricos, metodológicos e normativos, crenças e valores, que gozam num momento determinado do consenso dos especialistas, embora isso não implique a uniformidade. 
influência positivista. Ainda que onde a derrota da história, como parte das ciências sociais, foi mais notória é na incapacidade para compreender, e tanto mais para prever, as revoluções de 1989-1991 e a transição do socialismo ao capitalismo no Leste Europeu, que têm alterado o sentido progressivo da história do século XX. A história científica soube assimilar o marxismo historiográfico, mas resultou incompetente para analisar e explicar as realizações históricas do marxismo político. (Barros, 2007 - tradução nossa)

Esse quadro originou uma procura por novas formas de entender e escrever a história, em que sobressaem algumas tendências como: a volta aos gêneros mais conhecidos (história política, biografia histórica, história-relato); o apego às interpretações mais conservadoras e a um revisionismo destinado a atualizar as bases sociais da modernidade (Revolução Francesa e Inglesa) e das ditaduras implantadas no período de entreguerras na Alemanha, Itália e Espanha. ${ }^{10}$

A movimentação descrita anteriormente responde à predominância de um pensamento pós-modernista no qual, a princípio, se aceitam todas as versões e interpretações em função da sua fragmentação. Diante desse quadro, a história a debate propõe alguns pontos de vista para entender melhor os desdobramentos da história nessas últimas décadas. Em 2001, depois de oito anos da realização do primeiro congresso internacional, a história a debate apresentou seu manifesto com as ideias norteadoras para superar a crise, por

10 Um dos temas mais polêmicos envolvendo essa tendência conservadora resultou no denominado "revisionismo" sobre o Holocausto, que questiona as grandes obras publicadas no final da Segunda Guerra Mundial, destinadas a denunciar o assassinato de milhões de judeus. No limite, duvida dos crimes do III Reich. Coincidentemente, a vitória na Áustria da direita radical, o surgimento de grupos neofascistas em vários países da Europa entre as décadas de 1980 e 1990, a expansão do sentimento racista e xenófobo, assim como a simpatia por obras sustentadoras desses posicionamentos, criaram o clima próprio para a divulgação dessas interpretações questionadas pela história a debate. No Brasil, seguindo essa trajetória, publicou-se a obra Neonazismo, negacionismo e extremismo político (Milman \& Vizentini, 2000), disponível em http://www.derechos.org/nizkor/ brazil/libros/neonazis/. 
eles identificada como desdobramento "do continuísmo dos anos sessenta e setenta, do pós-modernismo e do retorno à velha História, a última 'novidade' historiográfica", das quais destacaremos algumas nas linhas seguintes.

Defendem que a escrita da história seja entendida como uma ciência na qual o ser humano descobre o passado enquanto o constrói, reconhecendo, nessa trajetória, a existência da subjetividade como melhor forma de se atingir a objetividade. O risco reside em cair na armadilha da fragmentação proposta pelo pós-modernismo no qual tudo vale e ainda ganha destaque inusitado. Pensando nas fontes, esse grupo advoga a ampliação do conceito de fontes nas quais incluiria, além das já usadas tradicionalmente na escrita da história, os registros não escritos de tipo material, oral ou iconográfico, e "as 'não-fontes', como os silêncios, erros e lacunas”, pois ajudariam na reconstrução e interpretação de fatos. Destacam, ainda, a incorporação de versões e interpretações já feitas por historiadores, pois "a história se faz com idéias, hipóteses, explicações e interpretações, que nos ajudam a descobrir e a construir as fontes". Para eles, o uso desse tipo de recurso, de alguma forma, já estava anunciado na historiografia das décadas de 1960 e 1970. Já naquele momento se anteviam temas posteriormente definidos como a história do gênero, a história oral e a incorporação das novas tecnologias. ${ }^{11}$

Para superar a crise da história, tal como mencionada pelos defensores da história a debate, propõem a interdisciplinaridade sem que isso signifique a perda da especificidade. Na verdade, aceitam uma aproximação com as ciências sociais visando estabelecer intercâmbios que incluam métodos, técnicas e enfoques para realizar interpretações mais sólidas e consistentes. De acordo com eles, três caminhos devem ser evitados nessa aproximação para que a história saia enriquecida:

11 Nesse ponto, destacam a ação do próprio grupo, que usa a internet como veículo de comunicação para ampliar a rede de contatos e promover debates. Pessoalmente, creio que não deva ser confundido o meio com o fim. A internet é um grande aliado de qualquer ciência, mas até agora persistem dúvidas relacionadas à veracidade das informações divulgadas nela. 
1) perseguir uma impossível "ciência social unificada", centrada em qualquer outra disciplina, menosprezando o desenvolvimento interdisciplinar individual e coletivo;

2) fazer do diálogo entre história e ciências sociais a receita mágica para a "crise da história", que entendemos como mudança de paradigmas;

3) diluir o conhecimento histórico em outras disciplinas na tentativa de criar narrativas sólidas destinadas a valorizar o trabalho dos historiadores. (ibidem)

Diante da fragmentação e da crise da "história total" dos anos 1960 e 1970, a história a debate lembra o perigo que representa a fragmentação de temas e escolas. Incentiva a construção de uma problemática comum estudada, nas mais diversas partes do mundo, por pesquisadores reconhecidamente experientes no tema proposto. Assume a necessidade de "experimentar novas linhas mistas de estudo de fontes, temas, métodos e especialidades”. Salienta a inevitabilidade de realizar um trabalho comparativo, tanto quantitativa como qualitativamente, para ampliar os conhecimentos sobre as mais diversas realidades e impulsionar a reflexão e o debate, aceitando, inclusive, nessa interação, as interpretações vindas de outras disciplinas.

Para limitar a subjetividade nas pesquisas, a história a debate defende a pesquisa em grupo e a inserção do pesquisador em correntes ou escolas, desde que anuncie seu posicionamento nas suas apresentações e manifestações públicas. Para atingir esse objetivo, dois elementos são apresentados como essenciais no manifesto da história a debate: a necessidade de se trabalhar globalmente e a valorização da autonomia do historiador. A necessidade da globalidade emana da presença da ampliação das comunicações no âmbito mundial, resultando na interligação dos países e das temáticas estudadas. Essa interconexão via internet já tem papel importante na formação de novos consensos, indo de encontro ao anterior sistema de dependência, baseado em uma ou outra historiografia nacional e em intercâmbios acadêmicos elitistas, hierárquicos e lentos. 
Entretanto, para os defensores da história a debate, a globalização da história não implica a sua homogeneização. Ao contrário, como eles mesmos sustentam, "pensamos e exercemos a história, e a história da história, como docentes e investigadores inter-relacionados em diversos níveis: local, regional, nacional, continental e internacional/global". Com isso, além de superar o que denominam de "eurocentrismo", ganham-se diversidade e qualidade. Só isso, sem a autonomia do historiador, não levaria a lugar nenhum. Enxergam no mercado editorial e comunicacional, na escolha de determinados temas e métodos por opções políticas (ressurgimento de novos heróis), os grandes perigos que atentam contra a autonomia do historiador. Diante dessa ameaça, sugerem que

[...] é preciso recuperar a autonomia crítica dos historiadores e historiadoras em relação aos poderes estabelecidos para decidirmos como, o quê, por quê, e em que a investigação histórica nos exige: reconstruir tendências, associações e comunidades que girem em torno de projetos historiográficos, para além das convencionais áreas acadêmicas; utilizar internet como meio democrático e alternativo de comunicação, publicação e difusão de propostas e investigações; observar a evolução da história imediata, sem cair no presentismo, para captar as necessidades historiográficas, presentes e futuras, da sociedade civil local e global. (ibidem)

A história a debate assume uma posição de vanguarda dentro da historiografia. Reconhece a relevância do passado. Aceita que, no transcorrer do século XX, notadamente o período posterior à Segunda Guerra Mundial, houve um retrocesso no campo da historiografia resultante nas práticas neopositivistas, razão pela qual assume como prioridade o engajamento do historiador na defesa dos interesses da sociedade e na utilização das novas tecnologias como aliadas no combate às tendências retrógradas e conservadoras.

Para os defensores da história a debate, as novas tecnologias estão revolucionando o acesso à bibliografia e às fontes da história, "ultrapassando os limites do papel tanto para a investigação como para a 
publicação, possibilitando o surgimento de novas comunidades globais de historiadores". Nesse campo, a internet merece toda a atenção da história a debate. Por meio dela, vem a possibilidade de ampliar e transmitir informação de maneira horizontal a várias partes do mundo. Entretanto, essa prática não exclui o uso dos meios tradicionais na divulgação de resultados. Para eles, "a generalização da internet no mundo universitário, e no conjunto da sociedade, assim como a educação informatizada dos jovens, tornará essa nova historiografia um fator relevante da inacabada transição paradigmática entre o século XX e o XXI" (Barros, 2007).

Taxativamente, sustentam que é de fundamental importância para o historiador pensar seu tema, as fontes e os métodos, as perguntas e respostas, o interesse social, as implicações teóricas, as conclusões e as consequências de sua investigação. No âmbito da academia, não abrem mão de determinadas disciplinas na grade curricular, como metodologia, historiografia, filosofia da história e demais matérias teóricas destinadas a formar um bom historiador, criativo, mas com sólida fundamentação teórica. Quem se preocupa com a investigação histórica deve ter criticidade e perspectiva histórica, sem a qual corre o risco de repetir formulações já feitas, ou pior, retroceder e cair em armadilhas de claro teor conservador. Nessa mesma linha, o manifesto enfatiza a necessidade de se defender uma ética da história e dos historiadores que deve ser passada para a sociedade no sentido de incentivar as práticas comunitárias em detrimento das individuais. Por isso, adotam como tarefa a valorização da história e a adoção de medidas destinadas a defender a atuação do historiador, inclusive no âmbito trabalhista, para resguardar e valorizar sua profissão.

Ao se considerar vanguardista, a história a debate assume o compromisso com as causas sociais. Contudo, tal compromisso não adota um caráter panfletário. Para os historiadores dessa corrente, o engajamento implica o combate de mitos que manipulam e combatem a história, além de fomentar "o racismo, a intolerância, a exploração de classe, gênero ou etnia”. Sugerem que 
A relação do historiador com a realidade que o rodeia passa por sua análise em um contexto temporal contínuo. Se se aceita que a objetividade da ciência da história é inseparável da subjetividade (plural) do historiador, devemos concluir que não existem grandes diferenças qualitativas entre uma história imediata e uma história mediata, entre uma história mais contemporânea e uma história mais antiga. Tudo é história, se bem que quanto mais nos distanciamos da atualidade, maior é nossa responsabilidade, até por ausência das disciplinas mais presentistas. (ibidem)

Mesmo que o objeto de estudo esteja no passado, o historiador vive no presente, e esse presente está impregnado de futuros. Assim, reconhecem semelhanças com a história imediata, principalmente no que diz respeito ao compromisso social e político. Em definitivo, a historiografia depende dos historiadores e das práticas que desenvolvem no relacionamento com a sociedade. Fecham seu manifesto de maneira bastante clara, elaborando praticamente um roteiro para aqueles que acreditam nessa proposta. Apesar de ser um pouco longo, pela sua relevância, vale a pena ser transcrito integralmente.

A mudança de paradigmas historiográficos que propomos, desde 1993, caminha sobre as aceleradas transformações históricas iniciadas em 1989. Entre dezembro de 1999 (Seattle) e julho de 2001 (Genova), observamos o início de um movimento global sem precedentes contra os estragos da globalização que busca para já outras alternativas: o pensamento único é agora menos único. São muitos os que qualificam hoje como uma mudança civilizatória a globalização, a sociedade da informação, a nova revolução científico-tecnológica e os movimentos sociais globais: no entanto, não é fácil entrever o que nos prepara o futuro, mas há razões para esperança. Todos devemos colaborar. História a debate é parte ativa deste processo transformador: queremos mudar a história que se escreve e colaborar nas mudanças da história humana. De acordo com a evolução do debate historiográfico e da história mais imediata, nossas propostas receberam mais ou menos aceitação acadêmica, porém existem po- 
sições que, embora ainda sejam minoritárias no momento, devem ser consideradas criticamente para a formação do novo paradigma: o conjunto plural de valores e crenças que vão regular nossa profissão de historiador no novo século. Por ele a história nos absolverá, esperamos. (ibidem)

Não é preciso muito esforço para entender por que a comunicação prioriza, quando o tema é a história, as visões da história do tempo presente, da história imediata e da história a debate. Ao se preocupar com as questões mais recentes, é compreensível sua busca por estudos e teorias capazes de tecer abordagens sobre a contemporaneidade. Mas, a esta altura, nos parece bastante oportuno estabelecer algumas considerações, como fruto dessa aproximação, que, no nosso entender, devem ser pensadas para fortalecer, de maneira mais clara e transparente, essa afinidade.

Um dos pontos nevrálgicos diz respeito à questão do tempo. Os gêneros históricos vistos até aqui não trabalham, apenas, com o tempo atual. Sugerem, de maneira incisiva, o conhecimento do tempo passado e a preocupação com o tempo presente na tentativa de esboçar um tempo futuro. Ou seja, não tratam do tempo presente de maneira isolada ou desconectada de outras projeções, sejam anteriores, sejam com expectativas de um futuro oriundo das análises do atual e do passado. Justamente nessa trajetória é que se destaca o papel da memória, por ser uma das pistas nas quais se encontrariam impressas as marcas do passado necessárias para valorizar qualquer processo de mudança. Dessa maneira, a princípio, teríamos nela um bom suporte para apreender como o passado entende o presente e como o presente influencia a compreensão do passado.

Nessa relação, alguns cuidados são necessários. Atualmente, os avanços tecnológicos e a "democratização" do acesso à informação e aos meios de comunicação permitem que as pessoas estejam expostas a um excesso de informações como nunca tinha acontecido. Nesse excesso informacional, o historiador privilegia determinados acontecimentos considerados importantes para suas análises, depois de ter definido e exposto claramente seu método e recorte epistemológico. 
Sem isso, as tentativas para captar a realidade social, apresentada em suas múltiplas facetas, resultam problemáticas e confusas caso não sejam mostrados claramente os procedimentos a serem seguidos para o leitor ou receptor.

A abundância da informação, mesmo tendo sido sempre desejada pelos historiadores para realizar suas interpretações, levanta uma questão polêmica e de difícil abordagem. Para o historiador, a possibilidade de os dados serem manipulados e distorcidos ocasiona problemas de interpretação e valorização de alguns fatos. Diante desse perigo, as abordagens históricas mencionadas nas páginas anteriores sugerem que os fatos não sejam tratados de maneira isolada, e, sim, inseridos numa conjuntura na qual adquirem sentido e significado. Mesmo assim, sempre se realizam observações, sabendo-se dos riscos de ser parcial por não conhecer, na sua totalidade, as fontes desencadeadoras dos episódios abordados. Por essa razão, aceitam-se as reinterpretações constantes à luz da incorporação de novos documentos e novas fontes sobre o episódio abordado.

A complexidade da sociedade atual, na hora de construir a realidade, demanda abertura para outras áreas de conhecimento no intuito de obter o máximo de interpretações e versões provenientes dessas áreas que, somadas às especificidades da história, procuram responder ao amplo leque de fatores e dimensões com a finalidade de realizar uma explicação mais detalhada e em profundidade.

O historiador é o homem cidadão que vivenciou na sua trajetória sua inserção social. Mas a validade e interrogação epistemológica residem não no questionamento de sua existência social, nem na pertinência de sua denominação, mas no seu próprio funcionamento. Nele a interferência da subjetividade deve ser reconhecida. Essa parece ser uma das questões mais candentes na história do tempo presente, na história imediata e na história a debate, pois o historiador, envolvido no seu tema, acaba por inserir na suas análises certa dose de subjetividade. A questão central colocada diante dessa evidência não seria apenas a de discutir o valor real dos fatos na história, mas sua percepção e as condições históricas nas e pelas quais eles são percebidos, o que, de certa maneira, colocaria entraves a um abuso 
da subjetividade nas interpretações apresentadas como fruto das suas considerações.

Dessa maneira, o historiador evolui junto com seu tempo. Contudo, olhando a relação dos historiadores com os acontecimentos, percebe-se claramente a ruptura que realizam se comparados com as gerações anteriores. Apenas para ilustrar, o sentido e o valor da democracia que se experimentava na década de 1980, dentro de nosso país, é bem diferente do que se atribui hoje. Naquela época, discutia-se qual democracia seria a melhor para o Brasil, mas no fundo havia uma preocupação com a própria sobrevivência dela, por estarem ainda agindo na sociedade as forças identificadas com o modelo autoritário. Com o passar do tempo, já assegurada a ordem democrática, o debate de temas mais específicos, como a distribuição de renda, a questão das cotas e outros temas polêmicos, ganha força. Pensa-se, atualmente, que, dentro da democracia, ainda se deve avançar em determinados temas para termos, efetivamente, uma democracia de fato. Assim, processa-se, nessa trajetória, uma transformação que, no dizer de Chauveau \& Tétard (1999, p.33), "seriam os frutos do encontro entre as lições epistemológicas da evolução do contexto histórico e da percepção imediata da história”.

Assim, podemos concluir que essas abordagens da história, ao privilegiarem a análise dos acontecimentos, nos permitem aferir como funcionava um determinado sistema social, pois o acontecimento torna-se público e estabelece relações sociais, tema próprio das abordagens do historiador. De alguma maneira, essas considerações, dentre outras que poderiam ser feitas, sobressaem na apropriação da história pela comunicação. Entretanto, procurar aproximar as duas áreas envolve pontos passíveis de uma explanação mais detalhada, como veremos a seguir. 


\title{
4 \\ COMUNICAÇÃO E HISTÓRIA: APROXIMAÇÕES
}

\author{
"A história é êmula do tempo, repositório \\ dos fatos, testemunha do passado, exemplo do \\ presente, advertência do futuro." (Miguel de \\ Cervantes)
}

História do presente, história imediata ou história a debate? Afinal, como relacionar comunicação-história e, mais especificamente, em razão das nossas pesquisas, jornalismo e história? Essas perguntas incomodam, mas têm de ser respondidas, pois constantemente aparecem, levantando dúvidas, equívocos ou mal-entendidos. Embora, no passado, o tempo presente e o imediato fossem relegados dos domínios da história, ambos aparecem e são aceitos, há algum tempo, como terreno fértil para os historiadores. Essa conquista, no entanto, não é fruto de modismos acadêmicos, e sim de um movimento profundo, renovador, amadurecido, que busca inserir o presente nos domínios da história. No capítulo anterior, intencionalmente, apontávamos algumas versões nas quais encontrávamos elementos de convergências entre diversas interpretações de correntes históricas mais contemporâneas e as possibilidades de diálogo com a comunicação. Todavia, não se pode afirmar que essa relação seja pacífica ou que não mereça um aprofundamento mais detalhado. 
Existe uma nítida separação entre a história do tempo presente, a história imediata e a história a debate. A diferença entre elas incide no estabelecimento do tempo necessário, entre o historiador e o fato, para poder constituir uma interpretação, ou seja, elaborar uma narrativa capaz de ser aceita como tal. A história do tempo presente, nesse ponto concreto, embora em alguns momentos pareça ser confusa, reconhece a necessidade de se ter uma temporalidade, um distanciamento do fato para resgatar o maior número possível de componentes do cotidiano, úteis para reforçar interpretações decorrentes de uma estrutura concatenada, só perceptível com o passar do tempo. Entretanto, defende a não aceitação de uma periodização padrão, na qual se inseririam temas e assuntos díspares num espaço de tempo longo e recheado de acontecimentos das mais diversas naturezas. Isso não significa que se quebrem ou alterem os métodos e os procedimentos do historiador em relação ao seu objeto de estudo. Aceitar e defender temas ignorados ou esquecidos pela historiografia pode ser solucionado sem grandes traumas desde que se adotem procedimentos conhecidos pelos historiadores. Afinal, a própria evolução histórica já comprova esse desenvolvimento de temas e métodos peculiares a cada momento e a cada período.

A história do presente, em razão desse imperativo, segue os procedimentos de qualquer pesquisa histórica. O historiador do presente tenta restaurar a evolução dos acontecimentos numa duração que permita compreender por que o processo chegou à situação atual. Nesse sentido, ele se dedica a descrever as estruturas cujas transformações dão conta do surgimento de fatos ou fenômenos cuja origem, muito provavelmente, se situa sempre em médio ou longo prazo. Assim, a história do tempo presente tem um recuo temporal significativo. Contudo, é aceito que ela seja feita diante de seus atores. E porque o presente é sempre fugaz, os limites do tempo presente precisam ser revistos continuamente.

O mesmo não pode ser dito em relação à história imediata e à história a debate. Ambas defendem a coetaneidade como forma de tratar a história. Nessas duas concepções, a atualidade e a apropriação de todos os recursos ao alcance do pesquisador seriam o lócus e o 
modus operandi no qual exercita seu ofício. Os meios de comunicação, aceitos como instrumentos nos quais se manifestam os problemas a serem estudados, espelhariam uma realidade passível de crítica e de intervenção por parte dos historiadores. Mais ainda, coincidentemente, alguns dos seguidores dessas propostas navegaram nos dois campos, no da história e no da comunicação, principalmente no jornalismo. Dessa forma, o historiador tem relação direta com o tema, tornando-se, ele mesmo, um ator social da própria história, sem que seja necessário estabelecer um espaço entre os fatos e suas interpretações. Observa-se, dessa maneira, a coincidência de procedimentos entre essas abordagens e a comunicação.

Assim, a história imediata e a história a debate têm um papel social que tanto complementa a história do tempo presente quanto levanta matérias para as pautas das mídias. Falar do imediato, tal como visto por essas interpretações, significa aceitar o historiador conectado com as questões prementes de seu tempo. Ele não apenas busca entendê-las e explicá-las, mas também transformá-las. Exercita o protagonismo nos processos históricos e, mesmo diante dos perigos de fazer uma análise por demais subjetiva, não hesita perante os riscos provenientes dessa reflexão. A busca pela verdade histórica, ainda que impossível de se concretizar inteiramente, continua a ser o guia desse historiador. A autêntica justificação da história, tanto para a imediata como para a história a debate, não consistiria em imortalizar pessoas, tampouco em satisfazer a curiosidade intelectual de certos saberes enciclopédicos, menos ainda em abastecer museus e colecionadores de antiguidades. A história faz parte da maneira como os seres humanos explicam seu próprio lugar e seu mundo. Pode ajudar as pessoas a verem onde se encontram e aonde deverão chegar, aceitando, com isso, o engajamento do historiador nas causas sociais do mundo em que vive.

O comum a todas essas abordagens reside na aceitação de que o historiador se encontra imerso num mundo concreto, com suas peculiaridades e singularidades manifestas nas estruturas socioeconômicas, políticas e culturais configuradoras de um tipo de realidade com a qual depara e convive cotidianamente. Os questionamentos 
oriundos da sociedade afetam também o historiador e, de certa maneira, colocam interrogações com as quais é obrigado a lidar. Por isso, cada época acentua determinados temas em detrimento de outros.

As diferenças apontadas anteriormente não respondem às indagações iniciais deste capítulo. Evidenciam a impossibilidade de equiparar essas interpretações, o que não deve ser visto como algo adverso ou irreversível. Ilustram, claramente, a impossibilidade de se realizar uma escrita que contemple a história do presente e a história imediata ou a história a debate. A questão temporal as coloca em situações, se não antagônicas, pelo menos bem distantes para poder estabelecer um consenso. Assim, não se pode simplesmente juntar as abordagens de cada uma para "criar" uma nova maneira de apresentar a história que nos permita vinculá-la com a comunicação ou com o jornalismo.

Se aceitamos esse impasse, corremos o risco de tornar inútil nosso trabalho, uma vez que ele pretende mostrar que, apesar das diferenças, urge estabelecer uma aproximação entre a história e a comunicação em razão de suas semelhanças e por estarmos numa sociedade cada vez mais midiática. A questão, portanto, se não se rejeitam essas abordagens históricas do tempo presente, história a debate e história imediata, seria esboçar um percurso no intuito de estabelecer itens comuns e convergentes a todas essas visões. Pensamos que, dessa tentativa, resulta um movimento interessante no qual o jornalismo e essas correntes podem dialogar, trocar experiências e realizar um intercâmbio frutífero e útil para a sociedade. O debate dos anos 1970, entre a história-narrativa e a história-problema, tal como entendido por Furet (1989, 2001), pode abrir possibilidade de aproximação e contribuir para realizar pontes para aparar as diferenças.

Não pretendemos realizar umaanáliseexaustiva das contribuições de Furet, nem muito menos defender suas posições políticas pessoais das quais discordamos radicalmente, apenas destacamos o caminho sugerido por esse autor como alternativa para superar o impasse descrito anteriormente. Se a divergência se centra na questão do tempo, nada melhor do que incorporar a noção de tempo sugerida por Furet (1989, p.55), na qual se supera a visão clássica entendida 
como uma série de descontinuidades que adquirem sentido à medida que se elabora a narrativa. Nessa visão mais clássica do que seria a construção da história, de acordo com Furet, ocorre uma situação preocupante na medida em que o historiador forçaria a construção da continuidade mediante a narrativa para a qual ele realiza a seleção dos acontecimentos que lhe interessam. Nessa ótica, a maneira de se narrar a história só seria compreensível na medida em que os fatos mostram seu desfecho final. Essa questão nos leva a entender a narração como uma reconstrução de uma experiência vivida num espaço de tempo, no qual o historiador se coloca numa situação de ruptura em relação ao fato narrado. Segundo Furet (1989, p.83):

A significação desse tipo de história vincula-se com a sua localização no texto da narrativa analisada como reconstrução de uma experiência de vida no eixo do tempo, mas não se trata de um objeto "intelectualmente construído" que recebe uma significação a partir da análise de suas relações com outros objetos comparáveis, no interior de um sistema.

Essas observações, mesmo que feitas na década de 1970, são bastante animadoras na medida em que nos permitem aceitar o trabalho histórico como a reconstrução e a reinterpretação dos acontecimentos, independentemente do tempo cronológico no qual aconteceram. Assim, sempre o historiador estará reescrevendo o fato histórico, sem que isso implique a perda do rigor com as provas que vão aparecendo. A narrativa histórica nada perderá, pois com ela os acontecimentos revelam novas facetas e o conhecimento histórico se aprofundará. O tempo surge como elemento decantador de interpretações e não apenas como fator cronológico no qual se alocam os acontecimentos e se estabelecem as periodizações.

Podemos afirmar que, desde essa perspectiva, se uma das tarefas básicas do historiador se refere à investigação das transformações no tempo, ele precisa fornecer também critérios plausíveis que justifiquem a permanência e a validade de conceitos de passado, presente e futuro, legitimando determinadas articulações entre eles. Em outras 
palavras, precisa questionar, antes de tudo, as ferramentas intelectuais usadas, que orientam a sua visão e as escolhas preferenciais em relação aos modos de representação, uma vez que mudariam de época para época. O historiador precisa assumir a sua condição de construtor dos fatos que constituem os seus objetos de investigação (Furet 1989, p.57).

Justamente por aceitar a reinterpretação do passado e por sofrer influências dos dilemas do momento em que vive, as observações de Furet permitem avançar no procedimento de aproximação do historiador como alguém que dialoga com os tempos e problemas da época em que vive sem que isso ocasione rupturas temporais. Agora, tal procedimento seria insuficiente para justificar por que o historiador e o comunicador social devem dialogar e elaborar uma agenda para aprofundar seus procedimentos na (des)construção social da realidade. Um bom caminho que pode ajudar a entender suas especificidades e, consequentemente, estabelecer rumos de aproximação e de soluções benéficas para ambos é entender como se processa a elaboração de sua narrativa. Efetivamente, na maneira de apresentar resultados reside o campo de aproximação entre a história e o jornalismo. Talvez seja necessário lembrar as afirmações de Burke (1992) já apresentadas neste livro e que evidenciam essa aproximação, mas visando à construção e ao entendimento, não para enfatizar as diferenças.

Considerando as abordagens de Peter Burke (1992), os anos 1980 foram marcados por profundas crises, principalmente econômicas e culturais, que obrigaram os historiadores a rever seus posicionamentos anteriores, mais preocupados com as macroestruturas do que com as microestruturas. Os projetos da micro-história surgiam como possíveis respostas para entender o particular, o interesse por histórias instantâneas, contadas em perspectivas multivocais, como meios de esclarecer estruturas e atitudes mentais, esperanças, expectativas e experiências de vida para as quais a história não conseguia interpretações adequadas.

Assim, continuando com as observações de Burke, nos anos 1990, a narrativa apontava possibilidades de interpretação de algumas dessas particularidades. $\mathrm{Na}$ verdade, essa opção não afastou a 
consideração pelas macroestruturas, só que se verifica uma integração entre narrativa e análise. Claro que ele alerta para a necessidade de se definir claramente o tipo de narrativa a ser adotada pelo historiador. Não seria, prossegue Burke, algo que valorizasse a descontinuidade temporal ou a ruptura cronológica, próprio da literatura ou da narrativa ficcional. Sugere que essa volta da narrativa deve acentuar a criticidade do historiador sem perder o foco da dialética passado/ presente. Defende que o historiador precisava analisar os acontecimentos a serem relatados, a partir da posição de um observador posterior, assumindo que a sua voz se limita a ser uma entre outras que caminham de outras áreas de conhecimento nessa direção. Os historiadores deveriam desenvolver suas próprias técnicas ficcionais para suas obras factuais (Burke, 1992, p.337-41).

Inicialmente, devemos destacar que qualquer narrativa, tanto histórica como jornalística, representa um saber objetivo ou subjetivo do mundo. Tanto os historiadores como os jornalistas elaboram narrações de determinados fatos que adquirem sentido após serem descritos, construindo uma lógica compreensível e reconhecida pelos outros como válida e elucidativa. Assim, atribuem-se sentido e significações às coisas e aos atos que passam a fazer parte do nosso universo justamente por evidenciar um saber estabelecido pelo narrador. $\mathrm{O}$ encadeamento e a sequência arquitetados por aquele que elabora as narrativas interligam o passado, o presente o e futuro.

As narrativas elaboradas pelos meios de comunicação, normalmente, referem-se a acontecimentos considerados reais, ou seja, aqueles que de fato acontecem e que acabarão incluídos em gêneros como reportagens, documentários ou notícias, e aqueles mais próximos da ficção, como telenovelas, filmes ou outros programas voltados mais para o lazer e entretenimento. Em alguns momentos, essas narrativas comunicacionais se interligam e acabam misturando, por exemplo, fatos reais com ficcionais. Essa mistura, muitas vezes intencional, visa prender a atenção do público motivado pela sequência de episódios nos quais se mistura realidade com ficção, criando um sentido peculiar capaz de despertar interesse por temas ou situações das mais diversas áreas. 
Já na história, a narrativa procura elaborar a reconstrução dos fatos, incorporando crenças e valores destinados a dar veracidade à sua descrição. Para isso, aquele que tem contato com a narrativa histórica precisa encontrar na sua leitura argumentos plausíveis que justifiquem a interpretação do historiador. Olhando para as diversas correntes ou escolas historiográficas, verificam-se formas diferentes de construir as narrativas. Apenas como exemplo, as visões mais tradicionais elaboravam sequências em que a descrição procurava retratar os fatos tal como eles aconteceram, o que hoje é aceito como tarefa impossível de ser conseguida.

A narrativa em história, mais especificamente, observa e interpreta como os discursos sociais dominam as dimensões do tempo no qual aconteceram os fatos, garantindo, assim, a construção de relações elaboradoras de práticas sociais específicas a cada momento. Esses discursos são, antes de tudo, formas de intervenção mediante as quais o historiador ordena o tempo, descreve as redes sociais e cunha uma lógica portadora de sentido específico. A criação da narrativa histórica é o momento no qual o historiador, na condição de pessoa responsável pela elaboração dessa interpretação, determina as classificações, a posição dos fatos, dos homens, das ideias e onde e quando se consolidam as justificativas que ele considera convenientes para criar sua versão.

De alguma maneira, esses procedimentos podem ser observados na narrativa jornalística. Ela ocorre também em contextos peculiares e específicos, e usa recursos, normalmente mais amparados nas estratégias narrativas do texto, destinados a cativar seus receptores. A organização narrativa do discurso midiático não é aleatória, portanto realiza-se numa conjuntura claramente determinada e procura originar determinados efeitos bem específicos. No discurso jornalístico, os jornalistas servem-se de estratégias textuais que interferem na organização do texto, pois se utilizam de códigos, articulações sintáticas e pragmáticas, além de outros recursos da linguagem, que levam a uma interpretação por parte do destinatário ou receptor.

Novamente, verificam-se aproximações entre a narrativa jornalística e a histórica, uma vez que, por suas construções, as duas 
tornam-se meios pelos quais ambas exercitam a interpretação destinada a influenciar o seu destinatário final. Suas práticas não são apenas relatos representativos, mas sim elaborações socioculturais nas quais se reconstituem fatos e versões portadores de uma lógica carregada de intenções e valores manifestos nas crenças de quem elabora o texto. A realidade recriada adquire, então, nova estrutura, clímax e desfechos prontos para serem absorvidos pelos públicos-alvo, que, dessa forma, passam a incorporar esses conhecimentos para construir sua sociabilidade. Aceitando que a narração não é neutra, fica, então, um alerta no sentido de atentar para alguns cuidados necessários quando se pretende decodificar as intenções do narrador, seja jornalista, seja historiador.

Se nenhuma narrativa é ingênua, as análises dos textos devem, portanto, compreender as estratégias e intenções textuais do narrador e a maneira como o leitor reinterpreta esses códigos neles contidos. Da perspectiva da história, um historiador que tem contribuído para valorizar a narrativa é Peter Gay (1990). Embora ele reconheça que a narrativa da história se assemelha muito ao estilo literário, interessa-nos, aqui, resgatar algumas das suas contribuições esclarecedoras para entender como o historiador deve se conduzir na hora de escrever. O estilo que o historiador desenvolve, lembra Gay, não representa unicamente uma questão estética, mas sim uma forma de mostrar um conhecimento com seus valores e ideologias. Desse modo, num sentido mais amplo, a forma de descrever os fatos revela mais do que a cultura em que o historiador está inserido. Ela explicita a própria maneira como o historiador concebe a apreensão do real (Gay, 1990, p.20-1). Essa observação de Gay enfatiza a necessidade de aproximar os esquemas narrativos próprios do gênero literário e da comunicação com a história. Coincide com aquilo que já tínhamos apontado anteriormente no sentido de dizer que a escrita serve para organizar conteúdos e dar sentido a determinados acontecimentos.

Vale a pena salientar que, entre os historiadores, essa questão não fica livre de algumas críticas. A mais importante diz respeito a considerar o texto e as análises textuais como únicas formas de entender e reconstituir a história. Assim, por exemplo, segundo Chartier (1994, p.110), "mesmo que escreva de uma forma 'literária', o historiador 
não faz literatura, e isso pelo fato de sua dupla dependência. Dependência em relação ao arquivo, portanto em relação ao passado do qual ele é vestígio".

Peter Burke (1992) referenda essa opinião e é taxativo ao sustentar que a historiografia não avançará muito, caso se engaje nessas práticas literárias. Ao efetuar uma aproximação entre a narrativa histórica e a jornalística, Burke assinala alguns pontos de convergência. Destaca o método de narração regressivo, muito utilizado nos romances modernos e que pode auxiliar o historiador a ressaltar para o leitor a pressão do passado sobre as sociedades, na medida em que a retomada de eventos e estruturas sociais anteriores reforça os laços entre o presente e que aconteceu antes dele. A literatura também oferece subsídios para que o historiador mostre ao leitor que sua obra não é reflexo de uma verdade acabada e, muito menos, que o historiador desenvolve uma função neutra.

Burke acredita que a historiografia vem renovando suas formas de elaborar a escrita. Para ele, a atual ênfase na forma do discurso histórico é mais bem compreendida quando o próprio ato de narrar e de se posicionar perante a narração começa a ser analisado historicamente. Passar de uma certa narrativa para um conhecimento histórico exige alguns cuidados. Esse deslocamento deriva de visões e concepções envolvidas na decodificação do que seja o real e do posicionamento ideológico e político do historiador.

De qualquer forma, deixando um pouco de lado essas observações, não se pode negar que a preocupação do historiador com a sua escrita é fundamental. Se considerarmos as reflexões de Michel de Certeau (1982) sobre as especificidades da narrativa histórica, segundo as quais essa é, ao mesmo tempo, um relato sobre o passado e um lugar de enunciação vinculado a técnicas de saber vigentes em um determinado corpo social, a narrativa e o uso das técnicas da escrita assumem um papel importante na medida em que permitem articular mais claramente ao historiador e ao seu objeto de pesquisa os fenômenos históricos.

As narrativas históricas contemporâneas não podem perder de vista seu compromisso com a reconstituição baseada em uma busca 
pela verdade. Não aquela verdade absoluta, mas uma verdade passível de alterações e de constantes reconstruções. Afinal, a historiografia pode ser concebida como um movimento constante de releituras do passado, o que não significa que haja um acúmulo ou progresso do saber histórico, e sim uma sequência de reinterpretações narrativas do passado que são passíveis de perdas, equívocos e revisões. O saber histórico se atualiza constantemente, interferindo nas construções passadas e na forma como se estabeleceram determinadas formas de apresentar os acontecimentos.

No jornalismo, as narrativas trabalham mais com o jogo de linguagem, com as ações estratégicas de significação das palavras no contexto, visando estabelecer um diálogo argumentativo entre os sujeitos. Por essa razão, a narrativa dos jornais não se realiza mediante a análise de textos isolados, mas sim do jornal como um todo. Uma foto ao lado de um texto pode, eventualmente, dar um sentido oposto ao que se poderia esperar em razão do lead ou da chamada realizada. Ainda, vale a pena pensar, mesmo entendendo o jornal como a materialização da notícia do dia, que alguns fatos acabam se projetando no tempo, sendo veiculados por vários dias, ou mesmo meses, dependendo de sua repercussão. Nesses casos, a narrativa demanda a leitura de todas as matérias publicadas, de maneira fragmentada, para poder ter o sentido dado pelo jornal ao fato estudado. Essa nova síntese, acumulada no decorrer dos dias, representa uma nova história, exigindo outra síntese mais completa do que aquela percebida diariamente, podendo, inclusive, modificar o objeto observado.

Outro cuidado importante a ser levado em consideração na narrativa jornalística diz respeito à identificação dos conflitos abordados, uma vez que neles se materializam as rupturas, as descontinuidades e as anomalias tratadas pelos jornais. De certa forma, pode-se afirmar que é em cima do conflito que se desenvolve a trama dos jornais. Eles, na sua continuidade, abrem as possibilidades de novas sequências e episódios, mantendo viva a narrativa, cativando os leitores curiosos com o desfecho do acontecimento. A "ação individual dos jornalistas" é perpassada pela "ação (talvez maior) dos diretores dos 
veículos", bem como pelas ideologias vigentes, o que a torna menos "individual”. Essa intervenção externa (ideologicamente marcada) de patrões e sociedade pode tanto se sobrepor quanto se confundir com as "intenções subjetivas" (ressalvadas abaixo). No caso de "se confundir", o jornalista "pensa" que age a partir de suas intenções subjetivas, mas essas intenções são ajustadas à empresa e ao contexto ideológico em que se insere, até mesmo inconscientemente.

Como o fato interfere na sociedade, gerando desequilíbrios e mostrando uma situação de conflito, a narrativa encontrada nos jornais revela o jogo entre os interesses envolvidos, dando ao jornalista uma função importante por tornar de interesse público fatos que passariam despercebidos pela grande maioria da população. Evidentemente, cada descrição imagina uma reconstituição particular dos fatos, mas se conecta com um todo, motivo pelo qual a autonomia detida pelos jornalistas também apresenta limites claramente marcados pelo compromisso com a verdade, a ética, o reconhecimento e a aceitação dos seus leitores. Os fatos saltam sobre o leitor, que, dificilmente, se deixará levar por uma realidade construída que ele considere alheia ou sem repercussões para seu cotidiano ou universo cultural. Talvez, por esse motivo, os textos dos jornalistas apresentem as vozes de fontes envolvidas nos episódios descritos no intuito de mostrar credibilidade.

Entretanto, os personagens, tal como vistos na narrativa dos jornalistas, costumam ser individualizados. Em determinados contextos, eles ofuscam o próprio fato, em parte, pela excessiva atenção e destaque dados por esses profissionais. Mas, se a intenção é entender como se elabora a narrativa dos jornais, prestar atenção a esses mecanismos ajuda na hora de decodificar seu papel na sequência dos fatos, inclusive fazendo a análise de como se construiu a imagem desse personagem nas páginas do jornal. Nunca é demais lembrar que os leitores realizam projeções dessas pessoas, podendo alterar ou recriar sentidos não desejados a partir do papel dado aos atores na construção das narrativas.

Dessa maneira, as narrativas jornalísticas podem conter intenções subjetivas, justamente por serem escritas por pessoas, motivo pelo 
qual essa ressalva tem que ser levada em consideração na análise da descrição elaborada pelo jornalismo. Ou seja, cabe salientar a necessidade de descobrir os dispositivos usados pelo jornalista para criar argumentos. Nessa tarefa de desmistificação e de decodificação, alguns pontos merecem ser levados em consideração.

Um dos principais consiste em ter em mente que os textos dos jornais procuram provocar o efeito do real, ou seja, tentam fazer que os leitores interpretem as informações como verdadeiras. Por isso sua ênfase na apresentação de fatos atuais, deixando de lado, muitas vezes, a contextualização que daria mais sentido às suas afirmações. Dessa maneira, uma das tarefas fundamentais do analista dos textos dos jornais diz respeito à capacidade de identificar os recursos usados para dar os efeitos de realidade ao que escreve. De alguma forma, essa narrativa promove a identificação do leitor com o conteúdo publicado, motivo pelo qual algumas figuras de linguagem prevalecem na narrativa dos meios impressos. ${ }^{1}$ A importância de destacar essa questão se encontra na finalidade mesma da notícia, ou seja, no grau de receptividade que lhe pode atribuir o receptor exposto aos recursos linguísticos, com desdobramentos na compreensão da matéria com a qual tem contato.

A forma como se escreve a história tem reservas em relação aos recursos linguísticos empregados na elaboração da narrativa. A rejeição maior com esse procedimento se assenta na corrente positivista que, preocupada em atribuir cientificidade à história, desconfiava do

1 A literatura especializada destaca as seguintes figuras de linguagem: verbos prospectivos, de sentimento, negativos, de conselho, de advertência; no uso de adjetivos afetivos, potenciais ou adjetivos de possessão; no uso de substantivos estigmatizados como terroristas, radicais, pivetes; nas exclamações, interrogações, comparações, ênfases, repetições e reticências, mais comuns no noticiário do que se pensa; nas figuras de linguagem (metáforas, sinédoques, sinonímias, hipérboles); nas ironias e paródias, que abrem âmbitos de significação; nos conteúdos implícitos, nas implicações de advérbios como "apenas", "de novo", "só”, "ainda”, comuns nas manchetes; nas pressuposições e tantos outros recursos linguísticos e extralinguísticos que proliferam na linguagem jornalística verbal e audiovisual. Destacamos, especialmente, o texto de Motta et al. (2005). 
uso da retórica ou de outras figuras de linguagem difíceis de serem aceitas como construtoras de objetividade nos relatos elaborados pelos historiadores. Claro que esse empenho e rigor no procedimento de sua profissão, próprio do positivismo, procurava dotar os historiadores de objetividade e transparência nas suas afirmações, o que viria a ser contestado ao longo do século XX pelas correntes que nele se consolidaram, algumas delas já vistas anteriormente. De qualquer forma, o isolamento e a pureza pretendidos pelos positivistas não vingaram, abrindo-se possibilidades de aproximação com as manifestações literárias, artísticas e dos meios de comunicação de massa, entre os quais se encontravam os jornais.

Aqui não pretendemos avaliar como essa aproximação se deu, mas enfatizaremos as convergências, por considerarmos que nelas encontraremos pontos de aproximação entre a história e as formas de se escrever na comunicação e no jornalismo em particular. Para Paul Ricoeur (1994, p.214), a narrativa se justifica por ser própria dos historiadores a descrição de uma sequência de ações e experiências representadas dentro de um determinado tempo e lugar. Nesse sentido, a aceitação da narrativa como forma de explicitar e mostrar um acontecimento contribui como uma ferramenta a mais para apresentar, com riqueza de detalhes, determinadas situações que perderiam significado, restringindo a narração ao caráter meramente científico.

Adotar uma sequência de fatos implica para o leitor - seja no jornalismo, seja na história - realizar um esforço de compreensão da trama construída. Em ambos os casos, trata-se de acompanhar o raciocínio elaborado por aquele que narra e compreender que o evento inicial leva a um desfecho final definitivo. Tanto a escrita da história como a encontrada nos meios de comunicação impressos passam pela organização desse fio condutor que une os acontecimentos, até aqueles visivelmente discordantes, a fim de conferir sentido a um todo maior que não é uma soma de elementos, mas, sim, um conjunto coerente que expressa opiniões e sequências inteligíveis. Os personagens que compõem essa trama seguem ordens diferentes, pois o historiador narra os feitos veiculados ao âmbito do privado e do público, e o jornalista, de maneira muito semelhante ao historiador, 
traz à esfera pública pessoas ou situações que poderiam muito bem passar despercebidas sem sua ação investigativa.

Mesmo estudando questões tão divergentes como temas atinentes às relações das pessoas, das classes ou dos Estados, a narrativa, seja histórica, seja jornalística, é imprescindível para mostrar o desenrolar dos fatos sociais. Ricoeur (1994, p.217), referindo-se à história, vai mais longe nas suas propostas para evidenciar a necessidade da narrativa, chegando a afirmar que, mesmo quando o objetivo do historiador é falar de tendências e correntes, a narrativa seria o meio pelo qual se cria a unidade orgânica das ideias de cada uma, de modo que tais tendências e correntes também figuram como personagens de uma história que deve ser acompanhada ao longo da sucessão de acontecimentos que a formam. $\mathrm{O}$ mesmo se pode dizer do jornalismo e de suas teorias. ${ }^{2}$

Nesse sentido, a ideia de Paul Veyne (1983) de que a escrita da história passa pela armação de uma intriga encontra respaldo. Para Veyne (1983, p.48), os fatos não existem isoladamente, motivo pelo qual a construção da narrativa histórica não passaria de um ato humano, em que a concatenação obedece a uma lógica objetiva destinada a realizar ligações e explicações de determinados acontecimentos. Nessa perspectiva, a narrativa, construída pelo historiador, representa interesses e objetivos que espelham a crença de quem escreve, por ser ele quem decide o que deve ser inserido ou excluído na sua escrita. $\mathrm{O}$ ato de escrever, portanto, resultaria numa prática na qual o historiador ou o narrador insere elementos considerados importantes sem se pensar que ele teria a possibilidade de inventar ou desconsiderar suas fontes. Resulta dessa visão a probabilidade da aproximação entre a história e o jornalismo na medida em que ambos apuram o estilo, usando os recursos de linguagem que em momento algum deve desviar o foco final, ou seja, construir uma narrativa explicativa, interpretativa e fundamentada em fatos ou fontes.

Assim, pode-se afirmar que a narrativa histórica foge da simples elaboração de sequências de acontecimentos e valoriza a maneira

2 Sobre essa trajetória e essa perspectiva, ver Marcondes Filho (1993). 
como se lavraram os processos resultantes nesses eventos. Nessa reconstrução e no modo de elaborar sua narrativa, o historiador escolhe a forma mais apropriada, assemelhando-se ao processo jornalístico por ter que desenvolver um enredo, uma trama com um seguimento capaz de recriar uma interpretação sólida, inteligível, de tal forma que não seja uma mera crônica. Trata-se de uma operação também de linguagem, pois demanda uma harmonização e criação que se encontram facilmente na literatura. A compilação dos fatos, em função dos elementos apresentados nas linhas anteriores, torna o saber histórico público passível, portanto, de receber críticas e reformulações.

Vale a pena salientar que a narrativa histórica nem sempre é predefinida pelo historiador. Ela depende muito do tema e da crença ideológica e ética com a qual o pesquisador se alinha. Aliás, não seria exagero dizer que, normalmente, esses princípios se sobrepõem aos estéticos ou artísticos. De alguma maneira, com o jornalismo acontece algo parecido, pois a trajetória da notícia, desde que sai das mãos do jornalista até sua publicação, sofre adequações que podem alterar até o próprio sentido dado inicialmente por esse profissional. O importante, tanto para a história como para o jornalismo, é evitar o engessamento da escrita ao modelo preconcebido.

Da mesma maneira que os escritores têm à sua disposição um vasto leque de gêneros e estilos a partir dos quais tornam suas obras singulares e únicas, o historiador cria um "estilo" no qual encontra referenciais para poder expressar suas ideias. A singularidade e a originalidade de uma obra histórica estão justamente na articulação estabelecida pelo autor entre todos os elementos de sua narrativa, o que inclui o conteúdo, o tipo de explicação dos fatos, os pressupostos ético-ideológicos, bem como o gênero do enredo. Cada ciência utiliza estruturas narrativas para mostrar seus resultados, mas é bom destacar que só as narrativas não produzem os efeitos esperados. No caso da história, um componente que foge ao fazer do historiador diz respeito à ficção ou ao caráter fictício da narração. Os fatos acontecidos sempre devem estar presentes na hora de escrever, mesmo que neles seja possível estabelecer uma trama ou apresentar determinadas 
consequências. No jornalismo, é bastante comum recorrer a esses procedimentos para tornar o fato mais acessível para seus leitores.

Cardoso \& Malerba (2000) mostram uma polarização entre os historiadores com relação ao seu ofício. De um lado, estão os que assumem um viés mais pessimista, por verem a impossibilidade de se trabalhar com a veracidade das narrativas, e, de outro, aqueles que caminham no sentido oposto, ou seja, defendem que a narrativa histórica, fundamentada em critérios já amplamente aceitos e testados, não é um simples artifício literário. Pessoalmente, parece-nos bastante apropriado não negar que a narrativa da história possa se apropriar de aspectos fictícios e literários, mas sempre seu aporte deve ser útil para o avanço da sociedade. A criação e o uso de recursos para se expressar, mesmo sendo de outras áreas de conhecimento, no caso da história, nunca deixarão de ter tido uma materialização que precisa ser reinterpretada e adequada às indagações de cada época. Quando o historiador mostra os acontecimentos, ele está ao mesmo tempo dando uma explicação destes, e essa explicação não está pronta e acabada nos próprios documentos, motivo pelo qual ela precisa ser reinventada.

A forma de escrever no jornalismo e na história não deve levar a pensar que ambos têm características ou procedimentos semelhantes. Em determinados momentos, o jornalismo e a literatura trabalham com possibilidades, com ensaios sobre como aconteceu ou poderia ter acontecido. A história não pode se dar a esse luxo, pois as fontes e os demais elementos presentes na sua narrativa estabelecem condicionantes concretos que em nada se aproximam das tramas novelescas ou dos outros procedimentos encontrados nos mais diversos produtos da mídia. Isso não quer dizer que ambos não possam ter um diálogo e se inspirar mutuamente. Na opinião de Ricoeur (1994), o historiador aponta as razões pelas quais na reconstituição do passado um fato tem mais peso que outro. Nos produtos midiáticos, a construção se submete à finalidade desejada, não tendo, necessariamente, um compromisso com a reconstrução dos fatos. Justamente por trabalhar com a multiplicidade interpretativa dos acontecimentos, a forma narrativa histórica adquire liberdade em relação aos recursos narrativos. 
A narrativa histórica exerce, essencialmente, uma ação explicativa por meio da qual aproxima o leitor do fato descrito e interpretado. Por isso pode-se afirmar que uma narrativa bem desenvolvida deveria obrigatoriamente apresentar a função de explicação. Como lembra Ricoeur (1994, p.216), para compreender o porquê da conclusão de uma história é preciso acompanhá-la não como se se tratasse de uma argumentação lógica cujo desfecho é, pelo próprio mecanismo silogístico, obrigatório. É conveniente seguir todos os episódios que compõem a intriga em direção a um final não previsível que se explica retrospectivamente por meio dos eventos que o precederam. A narrativa do historiador inclui tantos fatos quanto necessários para que o leitor consiga acompanhar a trama a ser explicada.

Mas nem sempre os encadeamentos dos fatos históricos ou jornalísticos são coerentes a ponto de proporcionar uma compreensão aceitável. Ciente desse limite, o historiador pode, eventualmente, recorrer aos recursos ficcionais, desde que a finalidade do tema abordado não se perca nesses elementos. Já no jornalismo, seria prudente realizar o percurso inverso, ou seja, recorrer à história para contextualizar o leitor. O que não pode ser esquecida é a relação entre a história e o jornalismo com a sociedade. Nela, o historiador, pela sua escrita, ajuda na compreensão do passado ao mesmo tempo que esclarece determinados episódios nem sempre presentes no cotidiano da sociedade. Nesse ponto, a comunicação e a história, na medida em que constroem versões, coincidem, embora possam seguir caminhos diferentes. Nem toda literatura e tudo que se veicula nos meios de comunicação podem ser vistos apenas como entretenimento. Não são poucos, por exemplo, os escritores que fizeram de suas obras verdadeiras ferramentas de combate em nome de causas que transcenderam as discussões puramente estéticas, tornando-as dessa forma questões de crucial importância para as sociedades em que viveram. Cabe então aos historiadores e a outros profissionais que mantenham contato com a sociedade se aproximarem mais para ver onde podem estabelecer diálogos e onde essa aproximação torna-se mais complicada. 
As maneiras de elaborar as narrativas levam à compreensão das grandes interpretações sobre os fatos e, em momento algum, caem no vazio. Compreender as deficiências sociais serve para estabelecer análises mais acertadas e, pensando na sociedade atual - midiatizada como falávamos -, resulta quase impossível elaborar diagnósticos apenas do ponto de vista de um ramo do saber. Se a opção de adotar formas distintas de interpretar os contextos sociais permite entender como essas conjunturas atribuem significado às particularidades supostamente atípicas, revelando o seu significado mais abrangente e, consequentemente, o seu ajustamento a um sistema, também é possível imaginar que outros fenômenos estranhos pelas suas manifestações apontam as deficiências do sistema no qual nos encontramos inseridos. Assim, parece-nos que a soma de componentes, tal como apresentados nas diversas interpretações da história, e a forma de apresentar esses fatos apontam para um campo de análise bastante frutífero tanto para o historiador como para o jornalista.

Acreditamos que é desnecessário destacar que essa maneira de abordar determinados acontecimentos está ainda em construção e que não representa unanimidade. É possível vislumbrar ainda a história como totalidade sinalizada pela articulação do passado, presente e futuro e a apresentação de fatos totalmente desarticulados sem que apresentem ligação clara com qualquer contextualização. Isso se encontra tanto na história como no jornalismo. Agora, quando as duas realizam uma escrita sedimentada nos seus procedimentos mais conhecidos, tanto as pessoas como as conjunturas aparecem devidamente matizadas e especificadas com sentido de fácil apreensão pelos membros de uma determinada sociedade. Parece-nos bastante viável pensar numa maneira de estabelecer relações e pontos de vista múltiplos na hora de avaliar o passado e interpretar o presente, o que implica abrir mão de alguns posicionamentos pessoais para criar campos de convergência.

Pelo exposto até aqui, podemos afirmar que a comunicação social e a história, apesar de suas diferenças, realizam abordagens e interpretações que, quando dialogam, se enriquecem na compreensão dos fatos e nas repercussões destes na sociedade. Deve-se destacar 
que tal aproximação não prima pelo voluntarismo ou por outros posicionamentos preocupados em minimizar as diferenças existentes entre essas áreas. Nesse diálogo interdisciplinar, como em qualquer outro, a preservação da identidade, trajetória, metodologia e dos demais procedimentos de cada saber é um componente impossível de ser ignorado.

Assim, nesta altura do trabalho, iniciamos um exercício mais concreto no intuito de exemplificar como pode ser feita essa relação. Para isso, recapitularemos algumas das ideias apresentadas até aqui. A questão de fundo que nos preocupou, nesses últimos anos, diz respeito à forma como se opera a construção de interpretações sobre fatos acontecidos na sociedade. Tanto a história como a comunicação social partem, na elaboração de suas narrativas, de acontecimentos considerados marcantes por terem repercussão social. Em função da ressonância social, o jornalista e o historiador buscam explicações fundamentadas e coerentes para serem apresentadas à sociedade. Nessa trajetória de reconstituição, materializam-se as semelhanças e diferenças das duas narrativas.

O jornalismo mais contemporâneo prima pelo imediato em razão da necessidade de elaborar as matérias antes do fechamento da impressão, ou seja, trabalha com prazo determinado. ${ }^{3}$ Mesmo assim tem de respeitar procedimentos inerentes à ética da sua profissão como a busca da imparcialidade, a consulta de fontes diversas (o contraditório), a procura pela objetividade e pela atribuição de sentido à informação apresentada. ${ }^{4} \mathrm{O}$ tempo e o espaço, claramente

3 Salientamos que alguns cadernos dos jornais impressos são fechados com mais tempo, porém o jornalista tem nas suas atribuições diárias compromissos e funções de apresentar fatos para os quais esse tempo não existe, tornando-se refém do fechamento do jornal, que tem hora para poder ser impresso e chegar cedo, no dia seguinte, ao leitor.

4 Apenas para ilustrar, apresentamos alguns dos princípios do código deontológico do jornalista do sindicato dos jornalistas de Portugal:

1) $O$ jornalista deve relatar os fatos com rigor e exatidão e interpretá-los com honestidade. Os fatos devem ser comprovados, ouvindo as partes com interesses no caso. A diferença entre notícia e opinião deve ficar bem clara aos olhos do público. 
delimitados no jornalismo impresso, colocam sérios entraves aos profissionais na hora de aprofundar e dimensionar, de maneira adequada, os acontecimentos narrados. Já o historiador não convive tão intensamente com a rapidez e limitação diária de ter que mostrar resultados, o que não significa que não dialogue com o momento em que vive. O tempo e o espaço do historiador se projetam de maneira diferente, resultando em outro tipo de abordagem, mais elaborada e estruturada do que as informações publicadas no jornal diário.

O historiador, contudo, não pode prescindir da leitura dos jornais e de outros meios de comunicação, sem os quais não terá acesso aos acontecimentos que se passam pelo mundo. Por meio deles se (re)constituem (re)interpretações ou se tem acesso a determinados episódios de difícil compreensão. De alguma forma, o jornal liga as pessoas com o mundo e o historiador não fica imune a tal fato. Umberto Eco (2008), numa entrevista recente concedida ao jornal espanhol El País, ilustra bem essa questão:

Cuál sería hoy el papel de la información? Yo creo que perdemos mucho tiempo en plantearnos estas cuestiones mientras las generaciones más jóvenes sencillamente han dejado de leer los periódicos y se comunican a través de SMS. Yo no puedo desprenderme de los periódicos; para mí, la lectura de prensa es la oración de la mañana del hombre moderno; no puedo tomar café por la mañana si no tengo por lo menos dos periódicos para leer. Pero a lo mejor somos los restos de una

2) O jornalista deve combater a censura e o sensacionalismo e considerar a acusação sem provas e o plágio como faltas graves profissionais.

3) O jornalista deve considerar como critério fundamental a identificação de suas fontes. O jornalista não deve revelar, mesmo em juízo, as suas fontes confidenciais de informação nem desrespeitar os compromissos assumidos, salvo se o tentarem usar para canalizar informações falsas. As opiniões devem sempre ser atribuídas.

4) O jornalista deve respeitar a privacidade dos cidadãos, salvo quando estiver em jogo o interesse público ou a conduta do indivíduo contradiga, manifestamente, valores e princípios que publicamente defende.

5) O jornalista deve recusar funções e benefícios suscetíveis de comprometer o seu estatuto de independência e a sua integridade profissional. 
civilización, porque los periódicos tienen muchas páginas, no mucha información. Sobre el mismo tema hay cuatro artículos que a lo mejor dicen lo mismo... Existe la abundancia de información, pero también la abundancia de la misma información. No sé si se acuerda de mi teoría del Fiji Journal. Yo estaba en las islas Fiji buscando información sobre los corales para mi libro La isla del día antes, y a mi hotel llegaba cada mañana el Fiji Journal, que tenía ocho páginas, seis de publicidad, una de noticias locales y otra de noticias internacionales. Aquel mes que estuve allí estaba a punto de estallar la primera guerra del Golfo, y en Italia había caído el primer Gobierno de Berlusconi. Me enteré de todo porque en una sola página de noticias internacionales, en tres o cuatro líneas, me daban las noticias más importantes.

Como Internet. Acudimos a Internet para conocer las noticias más importantes. La información de los periódicos será cada vez más irrelevante, más diversión que información. Ya no te dicen qué decidió el Gobierno francés, sino que te dan cuatro páginas de cotilleo sobre Carla Bruni y Sarkozy. Los periódicos se parecen cada vez más a las revistas que te daban en la peluquería o en la sala de espera del dentista.

Algumas considerações de Umberto Eco evidenciam questões relevantes envolvidas nesse relacionamento entre a história e o jornalismo. De fato, além de lamentar a queda constante na leitura dos jornais, por parte das gerações mais jovens, ressalta um tema importante relacionado ao que se pode considerar informação, essa sim uma preocupação vital para o historiador. Em sua opinião, muitas partes do jornal seriam dispensáveis, mas ficar sem esse meio de comunicação implicaria permanecer desatualizado diante de algumas mudanças importantes que acontecem no mundo. Alerta para a tendência de sínteses encontrada nos jornais da atualidade, fenômeno este conhecido como jornalismo pós-televisivo por tentar reproduzir o formato de notícias tal como se veiculam na televisão, ou seja, curtas, diretas, sem grandes interpretações, pois o leitor, teoricamente, não teria tempo para ler páginas inteiras sobre o mesmo tema. Como depende da informação, ela deve vir já pronta, sintetizada e interpretada de tal forma que, lendo as manchetes, já se sabe o que 
acontece. Convém manter um distanciamento para não se tornar refém do momento, do imediato, e elaborar uma interpretação mais fundamentada. Mas, não resta nenhuma dúvida, sem o jornal a sensação que resta é a de permanecer ilhado, desconectado do mundo.

Se Umberto Eco reconhece a influência do jornalismo no seu cotidiano, não estaríamos exagerando ao afirmar que esse procedimento se repete com a maioria das pessoas em qualquer sociedade. Portanto, entendemos que a informação encontrada nos meios impressos, independentemente de sua repercussão, ocasiona interferências na sociedade por apresentar conteúdos desencadeadores de ideias e debates destinados a formar opiniões entre os leitores. A atuação social das pessoas, dessa maneira, encontra no jornal uma referência na medida em que alimenta o diálogo, oferece versões e apresenta determinados fatos. Nesse processo, a história entra para dialogar e ampliar o imediato, tal como apresentado pelo jornalismo. Sua preocupação, na construção de uma narrativa mais densa e contextualizada, resulta na necessidade de elaborar um quadro de fundo no qual os acontecimentos do dia a dia adquirem um sentido mais profundo e coerente. A contextualização, entre outras coisas, forma uma totalidade importante para evitar a superficialidade muitas vezes decorrente da rapidez e velocidade com a qual o jornalista se vê obrigado a conviver para realizar, a contento, sua jornada de trabalho.

Nesse âmbito, jornalismo e história se encontram. Ambos estabelecem pautas comuns que se enriquecem quando existe uma aproximação real na qual se cruzam saberes e experiências peculiares a cada área. A crítica do jornalismo de que a história trabalha com o passado desaparece, uma vez que o passado se relaciona com a atualidade de maneira clara e direta. $\mathrm{O}$ passado tem uma analogia íntima com o presente e com a atualidade. Pela história, elaboramos reconstituições interpretativas de modelos sociais, econômicos, políticos e culturais que desembocam na atualidade. Resulta tão importante desvendar o passado como interpretar o presente, o momento atual. As posições metodológicas e ideológicas, as crenças e as convicções pessoais, as maneiras de avaliar o momento em que se vive formam fatores presentes na elaboração de seus trabalhos 
tanto para os historiadores como para os jornalistas. A neutralidade em ambas as profissões não existe.

O jornalista, no exercício de suas atividades, seleciona e torna públicos determinados acontecimentos em prejuízo de outros. A decisão para realizar essa operação resulta dos critérios assumidos pelo jornal e pelo que o jornalista, individualmente, considera ser importante. Na medida em que acontece a aproximação e o conhecimento do saber histórico, não temos a menor dúvida, algumas notícias merecerão mais destaque e virão mais contextualizadas e mais bem estruturadas do que aquelas que não passam de meras notas de redação. Não que as notas de redação, uma vez tornadas públicas, não tenham seu valor. Ocorre que determinados temas e valores construídos no passado, portanto próximos do saber histórico, e ainda presentes na atualidade, incidem mais diretamente nas reflexões que eventualmente possam ser realizadas na sociedade no seu cotidiano. Ou seja, a aproximação cria um campo de reflexão e convergência que de forma alguma são excludentes.

Não pretendemos, nesta parte do trabalho, como salientávamos, elaborar um modelo ou realizar uma aproximação na qual não se respeitem as marcas específicas de cada ciência. Reconhecemos que em determinados assuntos cada uma deve seguir caminhos próprios. Ao aceitar as possibilidades de diálogo, insistimos na necessidade de se elaborarem trabalhos nos quais se apliquem procedimentos destinados a comprovar a viabilidade da aproximação. Essa é a tarefa que procuraremos desenvolver nas páginas seguintes. 
PARTe II

\section{COMUNICAÇÃO E CONTEMPORANEIDADE}



Não resulta fácil enveredar por caminhos destinados a juntar ciências tão próximas, mas tão peculiares na sua forma de agir e elaborar seus conteúdos. Contextualizar os temas abordados abre um leque de possibilidades reais de diálogo e de cooperação do qual tanto a história como a comunicação social saem beneficiadas. Assim, iniciamos esta segunda parte com uma tentativa concreta de exercitar uma reflexão mais apurada tomando como referência os episódios de 11 de setembro de 2001. Se entre os profissionais e nas redações dos jornais há uma crença de que os fatos estampados nas suas páginas servirão de referência para no futuro mantermos viva a memória e não nos esquecermos do passado, resta ver como os acontecimentos são construídos e apresentados para seus receptores por esses meios de comunicação. Acreditamos no poder de demarcação e de valorização de ideias que os meios exercem na sociedade em que atuam. De acordo com o professor Chaparro (1994, p.42), os meios nutrem "processos complexos de comunicação com informação, análises e opiniões que podem mudar os rumos de povos e nações". O ataque às torres gêmeas se enquadra num desses marcos suficientemente fortes como para desencadear mudanças estruturais e alterar a política externa de países, repercutindo, sem dúvida nenhuma, na ordem mundial vigente até aquele momento. 
Entretanto, restringir-se ao imediato resulta insuficiente para abordar, em profundidade, o fato delimitado para estudo. Como vimos nas páginas anteriores, a história pleiteia um distanciamento para enquadrar os temas estudados. Já o jornalismo segue outra trajetória, destinada a avaliar o maior número de dados e fontes possíveis para estabelecer uma narrativa coerente capaz de ser compreendida pelo seu leitor. Com base nessas nuanças, iniciamos esta segunda parte, com o capítulo 5 caracterizando o mundo em que vivemos como resultante do fim da guerra fria e a queda do Muro de Berlim. Sem adotar uma contemporaneidade que se torne uma camisa de força, inicialmente delimitamos a crise do Estado de bem-estar social como o parâmetro desencadeador de reações e desdobramentos que levariam à construção do modelo neoliberal, no qual se insere o tema proposto. Nessa trajetória, os autores nos quais fundamentamos nossas interpretações coincidem em apontar a exclusão e desigualdade social como marcas dessa nova configuração na qual se assenta a maioria dos países alinhados com essa corrente de pensamento.

Aceitar a concretização de mudanças em tão curto espaço de tempo nos leva ao setor produtivo no intuito de aferir como se alteram as relações de produção na transição do modelo liberal para o neoliberal. Como nos preocupa especificamente o âmbito da comunicação, apresentaremos alguns dos resultados inerentes a essas transformações no campo empresarial da comunicação, notadamente a denominada concentração midiática. Essa tendência é vista com grande preocupação por ir contra um dos princípios fundamentais relacionados com a pluralidade de fontes e interpretações capazes de valorar o papel democratizador da comunicação. Toda essa problemática é tratada ao longo do capítulo sexto.

Finalmente, por meio de um estudo de caso, no capítulo sétimo, tentamos aferir como se criam, via meios de comunicação, interpretações de fatos para as quais devemos ficar atentos por conterem manifestações e versões carregadas de sentido nem sempre confiáveis e passíveis de serem aceitas. Interpretar as notícias, levando em consideração a proposta de unir história e comunicação, representa o grande desafio no qual nos encontramos envolvidos e no qual temos 
investido nesses últimos anos. Uma leitura mais atenta já denuncia opções e tendências de interpretar os acontecimentos desde a ótica que lhe interessa. No transcorrer desse capítulo, as variáveis e os procedimentos seguidos pelos meios de comunicação delimitados servem de alerta no sentido de evidenciar como a história e a comunicação devem ficar alertas para não se deixar levar pelo cotidiano ou pelos valores dominantes num determinado momento. 



\section{5 \\ A CRISE DO ESTADO DE BEM-ESTAR \\ SOCIAL E A GLOBALIZAÇÃO: UM BALANÇO}

"Los desheredados de la tierra quieren ir a Disneyworld, no a las barricadas." (Thomas Friedman)

"Una frase como ésa merece un puesto en la posteridad al lado de la declaración de la reina María Antonieta cuando se enteró de que el pueblo de París se había revelado y reclamaba el pan que no tenía: ¡Que coman pasteles!, dijo.” (Ignacio Ramonet)

Existe uma coincidência entre representantes das mais diversas correntes de pensamento no sentido de apontar a crise do Estado de bem-estar social como um dos elementos importantes desencadeadores das transformações que levariam à nova configuração do mundo denominada Nova Ordem Internacional. ${ }^{1}$ O Estado de bem-estar

1 Aqui utilizaremos a expressão "Nova Ordem Internacional” para designar as discussões sobre o que pode ser a organização social e política pós-guerra fria. Essa expressão ganhou força quando, em 1988, o então presidente da União Soviética, Mikhail Gorbachev, falava ante as Nações Unidas sobre a necessidade de arbitrar um "consenso universal", pois a humanidade se dirigia para "uma nova ordem mundial”. Em 1990, o então presidente dos Estados Unidos, 
social era um projeto cogente para recuperar o vigor e a capacidade de expansão dos países capitalistas após a tensão social, econômica e política do período entre guerras. Tanto que o estabelecimento do Estado de bem-estar social, entre as décadas de 1940 e 1960, ficou conhecido como "era dourada do capitalismo" por ser um momento de desenvolvimento econômico, com garantias sociais e oferecimento, praticamente, de emprego pleno para a maioria da população nos países mais desenvolvidos. A expansão industrial, mesmo que com índices diferenciados, tanto acontecia nos países capitalistas como nos socialistas.

Esse cenário propiciou o crescimento econômico industrial e a implementação das políticas sociais com uma aliança entre os diferentes setores da sociedade: os empresários, a classe média e os trabalhadores. O momento dourado chegou a ser visto como uma nova Revolução Industrial, por causa do crescimento da produção mundial e do aumento de consumo. Toda essa expansão ocasionou uma nova reurbanização, acarretando consequências não desejáveis em razão do aumento do uso dos combustíveis fósseis (carvão, petróleo e gás natural), mas que pouco incomodavam, uma vez que os resultados econômicos minimizavam as vozes de quem alertava para a maneira como esse processo acontecia. Ainda deve ser lembrado que a aparente euforia não minimizava o embate, não declarado, da guerra fria.

Nesse contexto, as eventuais distensões desencadeavam medidas imprevistas, evidenciando a fragilidade na qual se construía o denominado desenvolvimento. De fato, bastou o acirramento entre os árabes e israelenses para alterar o quadro promissor. As crises do petróleo de 1973 e 1979 interfeririam de maneira decisiva no desencadeamento do fim do Estado de bem-estar social. No ambiente da

George Bush, aproveitava a expressão para descrever o novo nível de colaboração atingido entre as nações após a guerra fria, sobretudo com relação à atuação das Nações Unidas ao repelir a agressão produzida no Golfo Pérsico. Desde então, a frase caiu nos círculos acadêmicos e jornalísticos. Apesar dessas discussões, a nova ordem mundial carece ainda de definição real, motivo pelo qual ainda não existe consenso em relação ao conteúdo dessa expressão. 
guerra fria, essas crises, além de quadruplicar o valor do petróleo e do gás natural da URSS, representaram uma das jogadas do bloco soviético para estrangular o abastecimento de combustíveis da potência norte-americana. ${ }^{2}$

Essas crises do petróleo, somadas à insatisfação das empresas privadas com o modelo de Estado vigente, isto em razão das altas cargas de impostos cobradas pelo Estado de bem-estar social, levaram à consolidação das críticas das correntes defensoras de outras concepções de Estado e de sociedade. ${ }^{3}$ A expansão do Estado de bem-estar social começou a ser ameaçada em um momento crítico, em que a carga tributária atingiu níveis alarmantes para a lucratividade e o desempenho do setor privado, o que também cooperou para intensificar a crise no final da década de 1970 e início dos anos 1980.

A consequência imediata dessa crise econômica e estatal resultou na intensificação das pressões políticas em favor do desmantelamento do sistema de Estado de bem-estar social, considerado ineficaz para reverter esse quadro pouco promissor. As portas estavam abertas para novas propostas destinadas a enfrentar as altas taxas de inflação e os preocupantes índices de paralisação econômica.

2 A denominada crise de 1973 aconteceu em contrapartida ao apoio dos Estados Unidos dado a Israel em relação à ocupação de territórios palestinos durante a guerra do Yom Kippur. Como represália, os países árabes organizados na Opep decidiram aumentar o preço do petróleo em mais de 300\%. O embargo pretendia ainda pressionar o mundo ocidental a apoiar os árabes contra os israelenses. Em 1979, a paralisação da produção iraniana, como consequência da revolução islâmica liderada pelo aiatolá Khomeini, provocou o segundo grande choque do petróleo, elevando em mais de $1000 \%$ o preço médio do barril iraniano. Os preços permaneceriam altos até 1986, quando voltaram a cair.

3 Não se pretende desenvolver as ideias defendidas por Keynes, apenas destacamos algumas que são do nosso interesse. Para ele, a economia se alimenta do crescimento proporcionado pelo aumento de capital que, inevitavelmente, gera um ciclo de benefícios para toda a sociedade. Assim, o Estado teria como função principal estimular o crescimento agindo em setores em que a iniciativa privada não teria interesse. Daí resulta um Estado ativo, interventor nas questões econômicas e políticas, responsável final pelo desenvolvimento da sociedade. Para isso, os impostos forneceriam o capital necessário para implementar as políticas sociais. O resultado era um Estado voltado para manter o crescimento e o bem-estar da população. 
Dentre as muitas sugestões discutidas naquele momento, uma ganhou força, a denominada ideologia neoliberal. Perry Anderson (1995) aponta a década de 1940 como o momento no qual se sedimentaram as primeiras visões neoliberais na cidade de Mont Pèlerin. Nela, intelectuais do mundo inteiro se reuniam, anualmente, para debater, discutir e criticar as ideias dos seguidores de Keynes, ou seja, dos defensores do modelo de Estado de bem-estar social. Em contrapartida ao intervencionismo estatal, advogavam a implantação de um capitalismo livre de regras e de qualquer outro entrave que freasse seu desenvolvimento.

Anderson considera como fundador desse grupo Friederich Hayek. Para ele e os demais seguidores de suas teorias, os problemas enfrentados pelos países ocidentais provinham das pressões do operariado por melhores salários, o que resultava em despesas excessivas por parte do Estado. A solução, então, seria uma contenção dos gastos com bem-estar e a criação de "um exército de reserva" para imobilizar os sindicatos. O "exército de reserva" caracterizava as massas desempregadas que se intensificaram desde a instauração do Estado neoliberal. Assim, o Estado de bem-estar social adquiriu a imagem de mau administrador da economia, com a consequente desmoralização e a acusação de ser inoperante, constituindo um empecilho para o progresso econômico. Concomitantemente, defendiam-se a livre-iniciativa e a valorização das organizações econômicas, uma vez que elas detinham as condições para dinamizar a economia diante do fracasso do Estado.

Na avaliação de Hobsbawm (1995), também os anos 1970 aparecem como momento-chave no qual se operaram transformações importantes a ponto de inaugurar uma nova conjuntura econômica, política e social. Em sua opinião, vislumbra-se já o teor do que aconteceria, em termos de transformação política, nesse período pós-Estado de bem-estar social.

Encerrou-se um extenso período de governo centrista e moderadamente social-democrata [...]. Governos da direita ideológica, comprometidos com uma forma extrema de egoísmo comercial e 
laissez-faire, chegaram ao poder em vários países por volta de 1980. (Hobsbawm, 1995, p.245)

Desse modo, as ideias neoliberais, formuladas pela sociedade de Mont Pèlerin, encontravam uma razão para existir e todo um contexto para serem arraigadas. As fórmulas de Estado neoliberal apareciam como as melhores soluções para aquele momento e para o avanço do capitalismo na disputa com o bloco socialista em plena vigência da guerra fria. ${ }^{4}$ Dessa maneira, políticas neoliberais começaram a ser implantadas com a "transnacionalização" - expansões das empresas transnacionais - e pelo avanço e maior desenvolvimento das tecnologias modernas e dos sistemas financeiros.

A década de 1990 iniciou-se sobre as ruínas do muro de Berlim, entronizando o mercado como instância suprema de coordenação das atividades econômicas e instigando os Estados a baterem em retirada não só nas áreas em que - agora comprovadamente - não tinham competência para estar. (Dupas, 1999, p.230)

O neoliberalismo, então, ganha força no modelo capitalista e a nova economia de mercado se afirma. O novo liberalismo (neoliberalismo) preza o mercado livre global. Nele "as empresas, corporações e conglomerados transnacionais adquiriram preeminência sobre as economias nacionais" (Ianni, 1995, p.46). Dando sustentação ao processo, uma nova divisão internacional do trabalho e a flexibilização dos processos produtivos surgiram, entre outras manifestações do capitalismo, sempre em escala mundial.

Intensificou-se e generalizou-se o processo de dispersão geográfica da produção, ou das formas produtivas [...] tudo isso ampla-

4 Dentre as muitas ideias atribuídas ao neoliberalismo, quatro predominam: liberalização, privatização, desregulamentação, desestatização. Fruto delas tomam-se, especificamente, em função de cada realidade, outras medidas complementares, mas sempre procurando atender a esses quatro pilares. 
mente agilizado e generalizado com base nas técnicas eletrônicas [...] Globalizaram-se as instituições, os princípios jurídico-políticos, os padrões socioculturais e os ideais que constituem as condições e produtos civilizatórios do capitalismo. (Ianni, 1995, p.47-8)

Nessa conjuntura, surgem tentativas de explicar os rumos seguidos pelo mundo diante dos acontecimentos que mostravam o fim do modelo socialista e o triunfo do capitalismo agora sem opositores suficientemente fortes para questionar sua hegemonia. $\mathrm{O}$ acirramento das interpretações sobre essa nova ordem logo evidenciou o antagonismo de versões e interpretações, como veremos a seguir.

Mas voltemos, antes, às frases que iniciaram este capítulo. Elas foram extraídas de um debate sobre a globalização do qual participaram Thomas Friedman e Ignacio Ramonet. Friedman mantinha um posicionamento mais receptivo, mais aberto, quase de diálogo e de aceitação do fenômeno da globalização. Ramonet, ao contrário, tecia duras críticas ao processo da globalização, alertando sobre os males e as desigualdades que ocasiona, principalmente, entre os povos mais pobres do planeta. Os argumentos exibidos no transcorrer desse embate, consolidados nas suas obras, mostram a incompatibilidade de suas concepções. Abordaremos inicialmente o ponto de vista de Friedman, otimista na hora de avaliar os novos formatos que o mundo adquiria.

Para Friedman (1999, 2002), não é possível compreender o tempo em que se vive sem levar em consideração o passado, principalmente as últimas décadas do século XX, mais concretamente o período denominado "guerra fria”. Para ele, a globalização representa a substituição natural de um sistema decadente implantado no transcorrer dos anos em que o mundo viveu a polarização estabelecida entre o capitalismo e o socialismo. Tal sistema, salienta Friedman, não é mais uma nova moda ou tendência econômica, representa uma resposta a toda uma trajetória de erros acontecidos nas décadas anteriores. Esses erros, quase que inevitavelmente, conduziram o mundo para a globalização. Se antes o mundo vivia em função do confronto das tendências bipolares, na atualidade aparece integrado, inserido 
dentro de umas normas universais aceitas e válidas para todos, sem restrições.

Essa integração, segundo Friedman, ganhou força com a adoção das novas tecnologias no sistema produtivo, notadamente a computação, a microtecnologia, a fibra ótica e a internet, modelo vigente nos Estados Unidos. A globalização manifesta e cria sua própria cultura dominante - a cultura americana -, caracterizada pela tendência de homogeneização das outras culturas. As pessoas, de acordo com Friedman, estariam sendo levadas a se inserir numa comunidade cultural desconhecida até esse momento. Tal comunidade vive de maneira mais centralizada e totalitária, pois envolve as pessoas na sua totalidade. Nesse novo mundo, a diversidade cultural desaparece e prevalecem os valores da cultura dominante, ou seja, a americana.

Com base nisso, Friedman sustenta, categoricamente, que, seja para o bem ou para o mal, a globalização tende a americanizar as culturas. Ele conhece e expressa, de maneira clara e incisiva, as reações que essa situação de mudança gera no cotidiano das pessoas: perda da identidade, insegurança, medo, instabilidade e valorização do trabalho. Nesse novo mundo, a diversidade cultural desaparece.

Friedman toma cuidado em assentar suas observações nos estudos de outros economistas que contribuíram, de maneira decisiva, para a consolidação do processo da globalização: Josef Schumpeter e o presidente da Intel, Andy Grove. Esses autores comungam de um princípio comum: defesa da liberdade de circulação do capital no planeta. Schumpeter, antigo ministro austríaco da Economia e professor da Universidade Harvard, expressou em sua obra clássica, Capitalismo, socialismo e democracia, a crença de que a essência do capitalismo é um processo de destruição criativo por representar o ciclo perpétuo de destruição de produtos ou serviços velhos, menos eficientes, e sua consequente substituição por outros novos, mais eficazes. Friedman se apropria do caráter inovador de Schumpeter para justificar as novas formas de entender o funcionamento do capital.

Grove, em suas análises sobre a globalização, remonta à ideia de Schumpeter de que só os paranoicos sobrevivem no mundo contemporâneo. Por meio dessa assertiva, aborda e explica a vida levada 
pelas pessoas que moram em Silicon Valley. De alguma forma, essa maneira psicopata de viver - sempre dependendo das inovações, do trabalho e da tecnologia -, tal como fora entendida por Grove, penetrou no mundo dos negócios do capitalismo e da globalização. Ainda de Grove, Friedman extrai a noção de que na atualidade se realizam, de maneira cada vez mais rápida, dramáticas inovações que alteram totalmente a forma de se efetuar a produção no sistema industrial. Em razão desses avanços tecnológicos e da velocidade com que ocorrem as transformações, as inovações consideradas de ponta no sistema produtivo tornam-se obsoletas muitas vezes antes mesmo de chegar ao mercado. Por essa razão, afirmava Grove, só os paranoicos sobrevivem. O mundo está reservado para os que pensam no futuro, não para aqueles que vivem do passado ou permanecem apenas com a visão do presente. Inovação e criação seriam as duas condições essenciais para poder sobreviver nessa nova configuração social.

Dessa maneira, Friedman monta os alicerces de seu pensamento otimista em relação ao processo da globalização. Os principais argumentos apresentados para justificar seu ponto de vista podem ser resumidos nos itens seguintes:

a) Defesa parcial da noção Estado-nação, uma vez que no processo de implantação da globalização ainda é necessária a presença do Estado.

b) A relação entre Estado-nação e mercados globais tende a restringir as ações dos Estados, com a consequente delimitação de sua atuação, pois os centros econômicos mundiais adotam medidas que têm de ser incorporadas pelos países defensores desse processo da globalização. A propensão, portanto, seria chegar ao fim dos Estados nacionais.

c) A tendência caminha no sentido de estabelecer o equilíbrio entre o poder dos Estados e as liberdades individuais, ou, se preferir, colocar no mesmo patamar o individualismo e o poder coletivo. Aqui, Friedman apela, mais uma vez, para as novas tecnologias e as facilidades de mobilização social criadas 
pela globalização. Nesse sentido, para ele, não se podem colocar entraves nem à mobilização nem às iniciativas individuais.

As considerações de Friedman, nevrálgicas para o sistema global, ignoram a complexidade envolvida em temas tão delicados. De fato, as relações culturais e as divergências de identidade, as peculiaridades de cada povo e cada cultura, entre os inúmeros pontos que poderíamos apontar, são completamente menosprezadas. Suas observações justificam a supremacia dos mercados e a defesa da individualidade como formas de solucionar qualquer entrave questionador da livre-iniciativa ou da liberdade do sistema produtivo.

Não resta dúvida de que os desdobramentos das ideias desse autor ganharam grande impulso não apenas entre os frequentadores da sociedade de Mont Pèlerin, mas também entre outros "cristãos-novos", na medida em que se programavam medidas globalizadoras que aparentemente davam certo. Em praticamente todos os países, surgiram defensores de pontos de vista semelhantes aos de Friedman. No caso do Brasil, um desses autores identificados em inúmeros pontos com Friedman foi Mario Henrique Simonsen (1995). Em 1994, momento em que se adotava o Plano Real, Fernando Henrique Cardoso apresentou algumas ideias necessárias para que o Brasil chegasse preparado e competitivo ao mundo globalizado. Adiantou a proposta de algumas reformas que inevitavelmente deveriam ser realizadas para o país ter êxito no mundo globalizado. Apenas para ilustrar, dentre as propostas defendidas por Simonsen incluíam-se pontos como a regulação do mercado pela livre competição de preços (no sistema de livre comércio sobrevive quem acerta e desaparece quem erra), defesa do Estado como instrumento de superação dos obstáculos para adotar a livre-iniciativa, incorporação de medidas para desregulamentar e flexibilizar as relações de trabalho, a privatização das empresas estatais e a implementação das reformas da previdência e tributária para desonerar o Estado. Suas afirmações, evidentemente, não poupavam críticas ao modelo marxista de estatização e centralização da economia realizada pelo Estado. Para Simonsen (1995, p.47), a economia socialista é como um dinossauro 
cibernético. Funciona como uma panela de pressão sem válvula de segurança para a pressão que pode, eventualmente, sofrer.

Princípios como o do livre mercado, a livre-iniciativa, a manutenção de um Estado mínimo, modernização tecnológica e a supremacia da cultura americana - entendida como cultura dominante e hegemônica - constituem o eixo do novo sistema mundial proveniente da superação do modelo criado em razão da guerra fria. As vantagens inerentes a esse sistema em contraposição às dos anteriores correspondem à visão otimista da globalização. Não resta dúvida de que Friedman soube muito bem captar esses sinais como pontos essenciais e positivos para a nova ordem proveniente da superação da etapa da guerra fria.

De maneira totalmente oposta às observações de Friedman, Ignacio Ramonet (2001a, 2001b, 2002a, 2002b, 2003) traz para discussão ideias ignoradas pelo ex-ministro da Economia austríaco. Para esse jornalista e pensador, existem na globalização duas dinâmicas poderosas e contraditórias: fusão e fissão. Esse autor verifica como muitos Estados procuram alianças consideradas necessárias para sobreviver dentro desse mundo globalizado, movimento denominado de fusão. A ideia desejada nesse processo consiste na busca e soma de forças, principalmente econômicas, para conseguir garantias nas operações realizadas. Quanto maior for o potencial dos aliados - economicamente falando -, maior será o potencial de crescimento econômico. Entretanto, alerta Ramonet, em decorrência desse movimento de integração, diversas comunidades aparecem e entram em cena (fissão), perdendo, com o passar do tempo, seus valores e identidades por causa do contato com "aliados" mais poderosos. Por essa razão, Ramonet acredita na existência de um forte componente destrutivo dentro da globalização.

Como exemplo de fusão e fissão, Ramonet lembra o processo da unificação da União Europeia e o desmembramento da antiga URSS. No primeiro caso, ocorreu o fortalecimento econômico e político de alguns países (fusão). Culturas locais minoritárias entraram em processo de colisão com outras mais fortes e predominantes, sofrendo perdas de identidade, tendendo, consequentemente, a desaparecer 
(fissão). Já o desmembramento da União Soviética realizou um processo semelhante, embora seja mais político que cultural. De fato, enquanto permaneceu como uma união de repúblicas socialistas (fusão), exercia certo poder de pressão. Entretanto, a criação de diversos Estados e o surgimento de movimentos separatistas minaram a liderança exercida até esse momento (fissão). Obviamente, essas relações implicam componentes muito mais complexos do que os que aqui estamos apresentando. As citações de Ramonet apenas referendam a existência de um movimento contraditório na globalização.

Na sua ótica, as consequências sociais da globalização têm sido muito fortes e desastrosas, ocasionando inúmeros problemas para contingentes populacionais nos mais diversos continentes e países. Por essa razão, sua interpretação sobre a globalização não é tão otimista tal como acontecia com Friedman. Entende Ramonet que, na década de 1980, a globalização recebeu um forte impulso durante os governos ultraconservadores da primeira-ministra do Reino Unido, Margaret Thatcher, e do presidente dos Estados Unidos, Ronald Reagan. No mandato desses dois dirigentes, espalharam-se e se consideraram válidos, para o mundo inteiro, os princípios defendidos por Friedman. Concomitantemente, aumentaram as desigualdades, o desemprego e a deterioração dos serviços públicos. Esse processo, pelo menos até o momento em que acontece o debate, resultou na incerteza em relação ao futuro, na supremacia dos grupos mais poderosos, no estabelecimento da irracionalidade, na concentração de renda entre os países e nos países, em suma, numa perda constante da qualidade de vida para a maioria dos habitantes do planeta.

O que encontramos no mundo globalizado?, indaga-se Ramonet. Sua resposta é contundente: pobreza, analfabetismo, violência, surgimento de doenças, guerras... A quinta parte mais rica da humanidade possui e concentra $80 \%$ dos recursos do planeta, enquanto a quinta parte mais pobre fica, apenas, com $5 \%$ da riqueza. Do total da população mundial (ele considera o número de 6 bilhões de habitantes existentes no mundo), apenas 500 milhões vivem confortavelmente. Inclusive na União Europeia, encontram-se milhões de desempre- 
gados e pessoas nos limites da linha de pobreza. A fortuna das 358 pessoas mais ricas do mundo soma mais do que a renda dos $45 \%$ mais pobres. Esseé, de acordo com Ramonet, "o maravilhoso mundo novo da globalização".

Ramonet não acredita que a solução desses graves problemas possa vir, unicamente, da ação da mão invisível do mercado ou do crescimento econômico. Ele denomina as ideias de seu oponente como o corolário do pensamento único. Tal pensamento, ainda de acordo com Ramonet, nasceu em 1944, época do Acordo de Bretton Woods. Na evolução e consolidação de seus princípios, organismos e instituições econômicas e monetárias, como o Banco da França, o Bundesbank, a Comissão Europeia, o Fundo Monetário Internacional, a Organização para a Cooperação e Desenvolvimento Econômico, o Banco Mundial e a Organização Mundial do Comércio, passaram a ser os porta-vozes da política do pensamento único.

Dando continuidade às suas críticas, Ramonet sustenta que as instituições e os organismos internacionais, geralmente, usam o saber acumulado das universidades, ou de alguns membros das universidades, para ampliar e divulgar a nova ordem estabelecida no pós-1944. Ramonet afirma que praticamente todas as faculdades de economia do mundo, os jornalistas, os escritores, os cronistas e os dirigentes políticos aceitam os mandamentos da Nova Tábula da lei que acabam sendo constantemente repetidos pelos meios de comunicação de massa. Algumas das "bíblias" dessa nova ordem estabelecida seriam: The Economist, Far Eastern Economic Review, a agência Reuters e The Wall Street Journal. Os grandes investidores e detentores da riqueza mundial são fiéis leitores dessa literatura. Por sua vez, os meios anteriormente enumerados não deixam de repetir ideias e fatos que favorecem e legitimam o mundo globalizado. A repetição constante, tática usada pelo jornalismo para conseguir a persuasão, acaba minando as oposições, inclusive os marxistas mais convictos não ficam incólumes diante do volume de informações. Qual seria a grande ideia que querem que seja aceita pelas pessoas? Ramonet é taxativo ao sustentar que, apenas, desejam que se acredite no trunfo e na predominância da economia sobre a política. Aliás, 
esse seria o primeiro e principal mandamento do pensamento único: o deus do momento é o mercado.

Os outros mandamentos derivam do primeiro e principal: "a mão invisível do mercado corrige as desigualdades e disfunções do capitalismo", "os mercados financeiros possuem os sinais para orientar e determinar o movimento geral da economia", "o comércio livre sem barreiras é um fator de desenvolvimento econômico e social", "a globalização da produção manufatureira e, especialmente, dos fluxos financeiros deve ser estimulada a qualquer custo", "a divisão internacional do trabalho amaina as questões trabalhistas e diminui os custos com a mão de obra" e "ter uma moeda forte é uma obrigação para todos os países, assim como deve ser um princípio constante a desregulamentação e privatização das companhias estatais”.

A globalização, segundo Ramonet, se assenta em dois pilares ou paradigmas inabaláveis. O primeiro reside na comunicação que, de forma lenta e persistente, está desbancando a noção de progresso tal como se entendia antigamente. $\mathrm{O}$ segundo diz respeito ao mercado. Ele substitui, na atualidade, a coesão social e a ideia de que a sociedade deve funcionar como um relógio. Como se sabe, no relógio cada componente tem uma função específica, permitindo que a máquina de medir o tempo funcione de maneira harmônica e mecânica. Essa metáfora do século XVII, empregada para explicar o funcionamento social, é usada por Ramonet para exemplificar a predominância da nova lei social, política e econômica, base de sustentação social e alicerce do progresso: o mercado.

Para Ramonet, a explicação de como funciona a sociedade é mera consequência da submissão de todas as atividades diante desse novo "poder". Os valores fundamentais das sociedades inseridas na globalização são semelhantes nas mais diversas partes do planeta: benefícios rápidos, eficácia e competitividade. A sobrevivência social ocorre, apenas, para os mais fortes, para aqueles que levam esses valores até suas últimas manifestações. Sobreviver, afirma Ramonet, equivale a competir dentro de uma sociedade muito próxima da selvagem. Ocorre, de certo modo, o darwinismo econômico e social, no qual cada ser humano é chamado a mostrar suas competências 
e habilidades para sobreviver. Assim, prossegue Ramonet, existem dois tipos de pessoas na sociedade globalizada: os solventes e os insolventes ou, se preferir, os adaptados e os inadaptados ao mercado. O mercado é intransigente com os insolventes ou inadaptados. Caso não consigam seguir as novas normas estabelecidas, sofrerão a marginalização e a exclusão.

As desigualdades, os problemas sociais, o trunfo de mercado sobre o resto das atividades sociais, a concentração de riqueza nas mãos de poucos países e de poucas pessoas, a submissão e a junção dos meios de comunicação aos grandes grupos econômicos aparecem como o grande ideário imposto pela globalização. Como podemos perceber, essa concepção não apresenta o otimismo manifestado por Friedman nas suas abordagens relacionadas com a globalização. Ao contrário, a crítica e o pessimismo permeiam as observações de Ramonet.

Se pensarmos e compararmos as duas visões expostas nas páginas anteriores, mesmo que brevemente, verificaremos como algumas aproximações podem ser encontradas entre as manifestações de Friedman e de Ramonet. De fato, ambos coincidem quando afirmam que a globalização é um fenômeno mundial que surge em substituição de um modelo que se esgota na década de 1980. Talvez o radicalismo das suas visões leve a um mesmo patamar de explicações no sentido de que ambos não aceitam pontos que podem ser importantes para compreender os rumos no pós-guerra fria. Assim, outras interpretações devem ser trazidas à tona para termos elementos suficientes para estabelecer um balanço mais adequado sobre as versões envolvendo o mundo recente.

Um dos mais consistentes mapeamentos relacionados à globalização foi o realizado por Held \& McGrew (2001). A construção do conceito "globalização", segundo esses autores, conta apenas com rótulos que tentam estabelecer linhas mestras de argumentação sobre o tema, que buscam dar conta do assunto. Porém, ainda não se esgotaram as discussões sobre a globalização, tendo em vista a complexidade das diversas interpretações conhecidas atualmente.

Held \& McGrew (2001) dividem os estudos sobre a globalização em dois grandes grupos de pensamento: céticos e globalistas. Os 
primeiros defendem a ideia de que a globalização não é diferente da transnacionalização, pois ela não é total, não cobre todo o globo. Já os globalistas acreditam que a globalização parece ser indeterminada porque é produto de forças múltiplas e dinâmicas, processo de inter-relação nos campos político, econômico, cultural, militar, tecnológico etc., e deve ser entendida fase a fase, como uma mudança de longo prazo.

Os aspectos culturais da globalização neste texto não são, a priori, fundamentais. Porém, vale o esforço de estudá-los para entender sua dinâmica, em busca de uma maior compreensão desse movimento global. Céticos e globalistas, conforme Held \& McGrew (2001), admitem o fortalecimento de um nacionalismo cultural, mas discordam sobre sua força diante da exposição a outras culturas.

Os céticos apostam no vínculo entre as culturas nacionais e sua referência política, pois as identidades nacionais foram criadas em virtude do Estado-nação, pelo sistema de educação e da mídia. Tal sistema também consolidou a cultura popular na comunidade, tornando-a forte o bastante para não ser desgastada por forças transnacionais.

Já os globalistas dizem que a escala, a intensidade, a velocidade e o volume de comunicação entre países são tão volumosos que, além de aumentarem significativamente a exposição a outras culturas, rompem o elo do ambiente físico e a situação social, criando uma consciência global emergente, formando as bases culturais de uma sociedade civil global.

Compartilhando de uma visão ora globalista, ora cética sobre os aspectos culturais no mundo globalizado, Ianni (1999) acredita, primeiramente, que a cultura rompe fronteiras geográficas e histórico-culturais, fazendo que os povos encontrem novos horizontes com a universalização da informação, provocando assim a recriação das singularidades de cada cultura. Porém, o autor destaca que as mesmas relações que promovem a integração acabam suscitando o antagonismo, já que as diversidades e desigualdades são colocadas frente a frente, podendo, sim, conforme Held \& McGrew (2001, p.42), haver o reforço da cultura local: 
[...] embora os novos sistemas de comunicação possam dar acesso a similares distantes, eles também geram uma consciência da diferença. [...] Conquanto essa consciência possa favorecer a compreensão cultural, muitas vezes ela leva a uma acentuação do que é característico [...]. A consciência do "outro" não garante, em absoluto, a concordância intersubjetiva.

Vale ainda observar que o acesso à cultura nacional, como já dito anteriormente, é viabilizado tanto pelo Estado-nação e pelo sistema de educação quanto pelas empresas e mídia nacionais, enquanto o acesso a outras culturas se dá por meio de empresas multinacionais, seja de produtos importados, seja de mídia e entretenimento. Apesar de não estar isenta de interesses econômicos, a "máquina cultural" nacional fica, muitas vezes, em desvantagem diante do poderio econômico internacional e se vê recriada, por causa da integração promovida pelo contato cultural ditado pela economia.

Conhecer o processo do relacionamento entre culturas nacional e transnacional exige o estudo de muitas outras variáveis. Não cabe aqui promover uma discussão sobre o assunto, mas fica claro que ambas as possibilidades (de reforço da cultura nacional e do surgimento de uma global), defendidas por céticos e globalistas, podem acontecer, visto que, conforme Santos (2002), a globalização afeta a vida econômica, política e cultural, as relações interpessoais e até a subjetividade dos indivíduos, de uma maneira ou de outra.

Os meios de comunicação de massa assumem posição de ferramentas para todo o movimento de globalização. A eles se atribui o dinamismo com que se vencem fronteiras, culturas, idiomas, religiões, regimes políticos, diversidades e desigualdades socioeconômicas e hierarquias raciais:

Em poucos anos, na segunda metade do século XX, a indústria cultural revoluciona o mundo da cultura, transforma radicalmente o imaginário de todo o mundo. Forma-se uma cultura de massa mundial, tanto pela difusão das produções locais e nacionais como pela criação diretamente em escala mundial. São produções musi- 
cais, cinematográficas, teatrais, literárias e muitas outras, lançadas diretamente no mundo como signos mundiais ou da mundialização. (Ianni, 1995, p.94)

Sobre os aspectos econômicos, ainda segundo Held \& McGrew (2001, p.50-1), as diferenças entre o pensamento cético e o globalista aumentam. Para os céticos, não há a globalização da economia, mas, sim, uma internacionalização em que os vínculos entre determinados países se acentuam, excluindo outras nações; e não há um padrão de economia global:

Até entre os Estados da OCDE, que são sem dúvida as mais interligadas de todas as economias, as tendências contemporâneas sugerem apenas um grau limitado de integração econômica e financeira (Feldstein e Horioka, 1980; Neal, 1985; Zevin, 1992; Jones, 1995; Garrett, 1998). Seja no tocante às finanças, à tecnologia, ao trabalho ou à produção, os dados não confirmam a existência ou a emergência de uma economia global única (Hirst e Thompson, 1999). Até as empresas multinacionais, conclui-se, continuam predominantemente cativas dos mercados nacionais ou regionais, ao contrário de sua imagem popular de "capital móvel” (Tyson, 1991; Ruigrok e Tulder, 1995).

Os globalistas, por sua vez, destacam que, se não houvesse interação econômica, movimento de capitais e câmbio e comércio mundial instaurado, crises econômicas localizadas não produziriam colapsos em todo o globo. Contra-argumentando o pensamento cético, os globalistas defendem que a regionalização das economias dá mecanismos aos Estados para que se insiram nos mercados globais. Além disso, acreditam que não existe mais uma tríade econômica ${ }^{5}$ como apontam os céticos, mas, sim, uma era pós-hegemônica em

5 A tríade econômica, segundo os céticos, é formada por três grandes centros da economia global - Estados Unidos, Japão e Europa - que exerceriam poder sobre as relações econômicas mundiais. 
que "nenhum centro isolado pode ditar as regras do intercâmbio e do comércio globais" (ibidem, 2001, p.61).

Apesar de a ala globalista mais radical enxergar que os mercados globais escapam efetivamente à regulamentação política, outros reconhecem o surgimento de um sistema de gestão econômica multiestratificada e pluralista. Além dos órgãos regionais (Mercosul, União Europeia...) e da sociedade civil transnacional emergente (Câmara Internacional do Comércio, campanhas por interesses comuns...), existem as instituições multilaterais de gestão econômica global - de caráter público - como o Fundo Monetário Internacional (FMI), o Banco Mundial e a Organização Mundial do Comércio.

Vista por esse prisma, a política da gestão econômica global é muito mais pluralista do que admitem os céticos, uma vez que as instituições globais e regionais exercem considerável autoridade independente. (Held \& McGrew, 2001, p.67)

Parte dos teóricos globalistas defende que as instituições multilaterais são locais, visto que o controle das grandes potências é mediado e a globalização econômica é contestada pelos Estados mais fracos e órgãos da sociedade civil organizada transnacionalmente.

Parte do pensamento globalista, no entanto, se aproxima do cético, pois acredita que tais instituições não têm autoridade independente quando adotam programas que ampliam o controle do mercado global sobre a vida econômica nacional, como agentes do capital global e dos países mais ricos do planeta. Para os céticos, a gestão da economia mundial ainda depende da disposição de os Estados mais poderosos - na prática, os governos do G8 - policiarem o sistema, e, assim, são suas preferências e interesses que têm precedência. ${ }^{6}$

6 A sigla G8 corresponde ao grupo dos oito países mais ricos e influentes do mundo: Estados Unidos, Japão, Alemanha, Canadá, França, Itália, Reino Unido e Rússia. Antes chamada de G7, a sigla alterou-se com a inserção da Rússia, que ingressou no grupo em 1998. 
Stiglitz (2002) concorda com a visão de céticos e globalistas de orientação social-democrata e proporciona uma visão prática de como a gestão da economia globalizada - por meio das instituições multilaterais ditas independentes - atinge a autoridade política dos Estados-nação, traçando o perfil dessas agências e de suas políticas $e$ atividades.

O papel das instituições multilaterais assim se resume: a Organização Mundial do Comércio, que regula e fiscaliza o comércio internacional; o Banco Mundial, que ajuda com empréstimos os países em desenvolvimento a crescer com estabilidade e sustentabilidade e a reduzir a pobreza; e o Fundo Monetário Internacional (FMI), que surgiu com o intuito de exercer pressão sobre os países que não contribuem para o equilíbrio da economia mundial e fornecer liquidez na forma de empréstimos para que isso ocorra, quando necessário.

Ao criar o FMI, a cúpula de dirigentes das principais nações desenvolvidas do globo acreditava na necessidade de pressionar os países para obter políticas econômicas mais expansivas em benefício de todos. Entretanto, segundo Stiglitz (2002), atualmente o Fundo Monetário Internacional concede recursos somente aos países que adotam as políticas econômicas recomendadas por ele.

As políticas econômicas sugeridas pelo Fundo Monetário Internacional baseiam-se no fundamentalismo de mercado - uma "verdade absoluta" entre os economistas do FMI - que diz ser a demanda igual à oferta e os mercados, autorreguladores. Tal conjunto de políticas apresenta-se como um melhoramento do pensamento liberal, agora somado à tecnologia da informação e à consequente diminuição dos custos de operações financeiras e comerciais entre países.

A doutrina neoliberal também se manifesta nas próprias ideias que sustentam a globalização. Segundo Santos (2002, p. 132), isso ocorre:

[...] atrás da própria produção e difusão das idéias, do ensino e da pesquisa. Todos obedecem, de alguma maneira, aos parâmetros estabelecidos. [...] É o chamado pensamento único. [...] É uma forma de totalitarismo muito forte, insidiosa, porque se baseia em idéias que aparecem como centrais à própria idéia da democracia - liberdade 
de opinião, de imprensa, tolerância - utilizadas exatamente para suprimir a possibilidade de conhecimento do que é o mundo, do que são os países, os lugares.

Um característico exemplar de um "protocolo" neoliberal é o Consenso de Washington, um conjunto de políticas voltadas para solucionar os problemas da América Latina durante as décadas de 1980 e 1990. Suas recomendações estavam alicerçadas na austeridade fiscal, na privatização e na liberalização de mercado.

Tais políticas foram implementadas de maneira excessiva e muito rapidamente, excluindo outras políticas que se faziam necessárias, gerando crises quase que imediatamente. Stiglitz (2002, p.119-20) comenta as razões pelas quais o Consenso de Washington não deu certo, em virtude da maneira como foi colocado em prática:

[...] a liberalização do comércio, acompanhada por altas taxas de juros, é uma receita praticamente certa [...] para a criação de desemprego [...] a liberalização do mercado financeiro sem o acompanhamento de uma estrutura regulamentar apropriada é uma receita para a instabilidade econômica [...] a privatização, sem o acompanhamento de políticas de concorrência e a necessária supervisão para garantir que os monopólios não se tornem abusivos, pode ocasionar a elevação de preços [...] a austeridade fiscal, quando implementada às cegas, $[\ldots]$ pode levar a grande desemprego e a um retalhamento do contrato social.

Sem contar que, ainda para Stiglitz (2002), o Consenso de Washington não tratou devidamente de questões como distribuição de renda e justiça social. Na maior parte da América Latina, depois de uma curta explosão de crescimento no início da década de 1990, estabeleceram-se a estagnação e a recessão e, consequentemente, o aumento da desigualdade social e da miséria. Assim, as instituições financeiras internacionais não garantiram a estabilidade econômica global, não propiciaram o crescimento sustentável dos países em desenvolvimento e não tiveram êxito em reduzir a pobreza. 
Held \& McGrew (2001) também destacam que a globalização econômica está associada a uma defasagem acelerada entre os países ricos e pobres, o que começa a produzir colapsos sociais em todo o globo. Mas, sobre as causas da acentuação da desigualdade em nível mundial, céticos e globalistas têm visões extremamente distintas, bem como o são suas interpretações sobre as consequências do tema para a governabilidade e solidariedade nacional e internacional.

Sobre a governabilidade, Stiglitz (2002) destaca que a face econômica da globalização, apoiada nas instituições internacionais, detém poder de decisão que se sobrepõe, muitas vezes, à vontade de governos das nações em desenvolvimento. Caso um país não siga as condições impostas pelo FMI, este se recusa a emprestar-lhe dinheiro. Praticamente forçados a adotar as políticas sugeridas, os países em desenvolvimento acabam por abrir mão de parte de sua soberania, ficando expostos aos interesses do capital. Por esse e outros motivos, a globalização é vista como um sistema totalitário. Santos (2002, p.146) aponta tal característica:

Eu chamo a globalização de globalitarismo, porque estamos vivendo uma nova fase de totalitarismo. O sistema político utiliza os sistemas técnicos contemporâneos para produzir a atual globalização, conduzindo-nos para formas de relações econômicas implacáveis, que não aceitam discussão, que exigem obediência imediata.

A ideia de globalitarismo combina com o fato de que as políticas neoliberais não reconhecem a necessidade de um governo atuante na gestão da economia de seus países. Para os "homens" que regem a economia global, os mercados livres, desimpedidos, "liberais", funcionam perfeitamente. Tendo seu papel de gestor econômico reduzido, o Estado atua com dificuldades. Ianni (1995, p.48-9) aponta que:

Algumas das características "clássicas" do Estado-nação parecem modificadas, ou radicalmente transformadas. As condições e as possibilidades de soberania, projeto nacional, emancipação nacional, 
reforma institucional, liberalização das políticas econômicas ou revolução social, entre outras mudanças mais ou menos substantivas em âmbito nacional, passam a estar determinadas por exigências de instituições, organizações e corporações multilaterais, transnacionais ou propriamente mundiais, que pairam acima das nações.

Aí se encontram os entraves para o pleno exercício das políticas públicas nos países que seguem o pensamento neoliberal e as recomendações do Fundo Monetário Internacional. Entretanto, Stiglitz (2002, p.299) insiste no papel fundamental dos governos na escolha da política a ser seguida e na promoção da estabilidade econômica:

[...] os países que mais têm se beneficiado são os que assumiram o controle de seus próprios destinos e reconheceram o papel a ser desempenhado pelo governo no desenvolvimento, em vez de permanecerem na dependência de uma idéia de mercado auto-regulador capaz de solucionar os próprios problemas.

O Estado pode criar políticas alternativas às "recomendações" neoliberais e procurar garantir justiça social. Nações que assim o fizeram experimentaram crescimento e estabilidade econômica e social. Dentre essas políticas, Stiglitz (2002) ressalta a promoção de uma infraestrutura institucional e legal para que os mercados funcionem eficazmente, além de regular o setor financeiro, promover a tecnologia necessária e, principalmente, fornecer redes de segurança e combate à miséria.

Globalistas de orientação neoliberal acreditam que a abertura de mercado é o caminho para a geração de riquezas e a diminuição da pobreza (contando com o efeito em cascata da prosperidade) e aceitam as desigualdades como "naturais", acarretadas pela intervenção multilateral dita necessária para corrigir as consequências da globalização econômica desigual. Para os neoliberais, "tais diferenças desaparecerão com a modernização conduzida pelo mercado" (Held \& McGrew, 2001, p.70). 
Os globalistas de orientação social-democrata defendem que a globalização é responsável direta pelo aumento das disparidades em todo o planeta, sob três aspectos:

[...] a segmentação da força de trabalho mundial entre os que ganham e os que perdem com a globalização econômica; a crescente marginalização dos perdedores da economia global; e o desgaste da solidariedade social das nações, uma vez que os sistemas de assistência social não podem ou os governos não querem arcar com os custos de proteger os mais vulneráveis (Lawrence, 1996; Castells, 1997; Cox, 1997; Dicken, 1998; Gray, 1998; Scharpf, 1999).

De acordo com Held \& McGrew (2001, p.73), tais fatores acabam por dividir as nações e desgastar a base da solidariedade social tanto nos países de economias avançadas - onde a competitividade global enfraquece as coalizões sociais e inibe a aplicação de políticas eficientes de proteção social - quanto no mundo em desenvolvimento - onde "os programas de assistência social supervisionados pelo FMI e pelo Banco Mundial restringem severamente os gastos públicos com o bem-estar social".

Para os autores, há a necessidade de uma nova negociação global entre países ricos e pobres. Isso implicaria um repensar sobre a democracia como projeto nacional, não se esquecendo de que as nações devem estar inseridas num sistema de gestão global que combine eficiência econômica com segurança humana:

A reconstrução de um projeto social democrático exige a busca coordenada de programas nacionais, regionais e globais que regulem as forças da globalização econômica - a garantia, em outras palavras, de que os mercados globais comecem a servir às populações do mundo, e não o inverso. Estender a democracia social para além das fronteiras também depende de fortalecer os laços de solidariedade entre as forças sociais, nas diferentes regiões do mundo, que procuram contestar ou resistir aos termos da globalização econômica contemporânea. Assim como o sistema de Bretton Woods criou uma 
ordem econômica mundial conducente à busca da democracia social nacional, faz-se necessário um novo pacto (social democrático) global, afirmam muitos globalistas, para domar as forças da globalização econômica e criar uma ordem mundial mais justa e mais humana. (Held \& McGrew, 2001, p.73-4)

Para isso, o Estado-nação precisa assumir o controle da política econômica e social e, como explicitado anteriormente, buscar soluções para garantir justiça social, algo que o processo globalizatório até hoje não promoveu.

Parece evidente o desdobramento dessas visões para as empresas. Existe a necessidade de ampliar seu raio de ação, assim como se torna vital modernizar e diversificar sua produção. Na prática, passou-se de empresas multinacionais para transnacionais. Em razão do propósito de nosso trabalho, procuraremos verificar como tal processo se operou no âmbito da comunicação, pois seria ilusão que o caráter mercantil não chegasse a esse segmento mais voltado para a informação e o entretenimento. Essa preocupação se estuda mais detidamente no próximo capítulo. 


\title{
6 \\ A CONCENTRAÇÃO MIDIÁTICA EM TEMPOS DE NEOLIBERALISMO
}

\author{
"Tener una licencia de TV o radio es como \\ tener una licencia para imprimir dinero. [...] La \\ concentración del poder de los medios, el poder \\ de influenciar en la opinión pública, en manos de \\ pocas corporaciones, lleva fácilmente y de manera \\ natural a la censura y a la conformidad de pen- \\ samiento y cultura." (Jeff Cohen, fundador de \\ Fairness \& Accuracy in Reporting (Fair): The \\ National Media Watch Group)
}

Se o debate sobre a globalização aponta para transformações no âmbito político, econômico e social, a comunicação e as empresas comunicacionais não poderiam passar impunes a esse processo. Assim, neste momento nos parece oportuno abordar os desdobramentos da recente concentração midiática, fenômeno que vem ganhando força na hegemonia do neoliberalismo. Para compreender a dimensão do tema, procuraremos contextualizar a maneira como se origina tal processo a partir da década de 1970, momento no qual se iniciam grandes modificações, além de enfatizarmos os componentes econômicos nessa transformação. Inicialmente, procura-se apontar as medidas tomadas pelos países dirigentes para fazer valer seus pontos de vista. Os perigos de não identificar tais medidas surgem, ainda dentro da 
primeira parte, com a exposição de abordagens consideradas problemáticas, notadamente a que envolve a noção de império legitimadora das práticas econômicas nas quais agem os grupos transnacionais.

Num segundo momento, apresentamos as interpretações dadas à concentração midiática por estudiosos amplamente reconhecidos na academia. Sem dúvida, suas contribuições representam um esforço altamente significativo e importante na hora de entender a origem e a consolidação dos megagrupos midiáticos. Ainda, buscamos dar um significado aos dados e estudos desses autores, sempre mostrando a gravidade e a relevância envolvida por abordar e apresentar bens simbólicos para a população, alvo final da ação desses grupos.

Num terceiro momento, aprofundamos as implicações da supremacia de alguns grupos que dominam a informação. Novamente as contribuições de Ignacio Ramonet aparecem para explicar os desdobramentos da tal supremacia. Sua denúncia vai além da exposição do processo de concentração e aponta para um envolvimento de vários conglomerados que perpassam por todos os setores produtivos. Assim, a proposta de Ramonet é entendida como a de maior relevância para poder dimensionar o alcance real da formação das megacorporações.

Não se pode falar na concentração dos meios de comunicação sem retroceder no tempo e desembocar na década de 1970, período marcado por profundas transformações econômicas, políticas e sociais, tais como apresentadas anteriormente. O Banco Mundial, por exemplo, sob o comando de Robert McNamara, ex-secretário de Defesa do presidente Kennedy, passou a aplicar políticas mais racionais nas suas operações. Usando métodos matemáticos e estatísticos, imprimiu uma nova mentalidade na concepção de administração e gerenciamento empresarial que acabaria favorecendo os mecanismos de fusão e concentração das grandes corporações internacionais. Os "novos tempos" propiciaram o surgimento de especialistas altamente treinados e capacitados para implementar projetos, nos mais variados lugares do mundo, destinados a criar um novo imperialismo econômico capaz de garantir a supremacia das empresas e dos países adeptos dos princípios defendidos pelo pensamento neoliberal. Perkins (2005, p.9), ele próprio um desses executivos, define tais profissionais como "assassinos econômicos", ou seja: 
[...] profissionais altamente remunerados cujo trabalho é lesar países ao redor do mundo em golpes que se contam aos trilhões de dólares. Manipulando recursos financeiros do Banco Mundial, da Agência Americana para o Desenvolvimento Internacional, além de outras organizações americanas de "ajuda" ao exterior, eles os canalizam para os cofres de enormes corporações e para os bolsos de algumas famílias abastadas que controlam os recursos naturais do planeta.

Para Perkins, entre 1960 e 1970, inaugura-se a supremacia do pensamento militar-estratégico destinado a implementar a concentração e aumentar os lucros das corporações por métodos nem sempre legais. ${ }^{1}$ As empresas midiáticas não ficariam livres dessa tendência claramente identificada nos mais diversos segmentos do setor produtivo. Entretanto, a semelhança nas diretrizes políticas não pode ocultar as diferenças existentes entre os grupos da mídia e os das outras atividades econômicas. A mídia trabalha com produtos e bens simbólicos, nem sempre quantificáveis, materialmente falando, mas diretamente relacionados com a forma de entender e sustentar valores políticos, econômicos e culturais nas sociedades.

De maneira bastante semelhante às concepções de Perkins, Joseph E. Stiglitz (2002) aponta a Organização Mundial do Comércio (OMC), o Fundo Monetário Internacional (FMI), o Banco Mundial $(\mathrm{BM})$ e os países mais desenvolvidos como os principais responsáveis pela desigualdade e pobreza existentes entre as nações. Stiglitz, professor da Universidade Columbia, fez parte da equipe econômica do governo de Bill Clinton e foi, de 1997 a 2000, economista-chefe e presidente sênior do Banco Mundial. Seu vasto conhecimento sobre a economia mundial e as experiências adquiridas na sua passagem pelo BM tornaram Stiglitz um dos militantes mais respeitados nas

1 Perkins (2005), um ex-assassino econômico, define como instrumentos do seu trabalho a falsificação de relatórios financeiros, fraudes nos pleitos eleitorais, extorsões, sexo e assassinatos. Afirma que as mortes dos presidentes Jaime Roldós (Equador) e Omar Torrijos (Panamá) não passaram de assassinatos cometidos pela CIA por se oporem à política e aos interesses das grandes corporações americanas. 
suas críticas ao modelo econômico defendido pelo neoliberalismo, o FMI, o BM e a política externa dos Estados Unidos.

Stiglitz é categórico ao afirmar que o desdobramento de tais políticas resulta na desigualdade entre os países. Relata episódios concretos de como se implementam essas medidas. Um bom exemplo ilustrador da atuação dessas organizações, de acordo com Stiglitz, foi o acontecido na Etiópia. O país, com uma triste história de ditadura, guerra civil, seca e fome, parecia estar crescendo relativamente bem, recebendo a ajuda de empréstimos externos, já que sua única renda adicional residia nos impostos. O FMI, no entanto, como afirma Stiglitz (2002, p.56), decidiu cortar seu pacote de ajuda, equivalente a US\$127 milhões, pois:

Se um país não puder apresentar um número mínimo de parâmetros, o FMI suspende a ajuda e, geralmente, quando o faz, outros doadores também o fazem. É compreensível por que o Banco Mundial e o FMI não emprestam dinheiro a nações que não contem com uma boa estrutura macroeconômica estabelecida. Se os países tiverem grandes déficits e uma inflação galopante, há risco de o dinheiro não ser bem empregado.

O autor destaca como a função do FMI consiste em examinar as condições macroeconômicas de cada país para assegurar como está sobrevivendo de acordo com suas possibilidades, ou seja, apenas com sua renda - e os indicadores macroeconômicos da Etiópia eram satisfatórios. Apesar de o Banco Mundial ter provado que a renda obtida por meio de impostos, no país, era muito mais instável que a renda obtida por ajudas externas, o FMI considerou que ele não podia fazer seus cálculos contando com o auxílio externo, alegando não confiar, portanto, na sua posição orçamentária - motivo suficiente para suspender sua ajuda a esse país africano.

A postura do FMI, no entanto, estaria baseada em outras questões. Primeiro, porque o primeiro-ministro etíope, Meles Zenawi, insistiu em investir parte do dinheiro, que supostamente deveria ser utilizado para a criação das reservas (muito necessárias, segundo o 
Fundo, para manter a estabilidade em casos de crise), na construção de escolas e hospitais, alegando que a ajuda externa era muito instável para manter essas construções (o que, segundo Stiglitz, já teria sido pensado pelo financiamento externo, que teria garantido a provisão para manutenção dessas obras, além de existirem políticas públicas preparadas para lidar com uma possível interrupção dos auxílios).

Em segundo lugar, a Etiópia havia decidido pagar uma de suas dívidas com um banco americano, utilizando dinheiro de suas reservas, já que os gastos com os juros se demonstravam excessivos. Os Estados Unidos e o FMI se opuseram à decisão não por discordarem dela, mas pelo país não ter comunicado o fato previamente. Em terceiro lugar, queriam que o país abrisse seu sistema bancário à concorrência estrangeira, leiloasse os títulos do governo e liberalizasse o seu mercado financeiro, atitudes simplesmente descabidas se considerarmos a situação de desenvolvimento do país. Visto que a Etiópia não se mostrava aberta às condições impostas pelo Fundo (o que eles chamam, ironicamente, de reformas), ele suspendeu seu auxílio. O resultado para a Etiópia não poderia ter sido mais desastroso, uma vez que os índices de pobreza aumentaram, assim como sua dívida externa.

No amplo universo das explanações destinadas a explicar a concentração das empresas relacionadas com a produção midiática e os demais setores produtivos, surgem interpretações duvidosas quanto à eficácia de suas afirmações. Apenas como exemplo, citamos Império, obra de Antonio Negri e Michael Hardt (2001). Nela, os autores formulam um falso dilema relacionado com a concentração empresarial. De acordo com eles, constata-se, na contemporaneidade, um deslocamento do poder. Tal deslocamento passou do Estado para as grandes corporações internacionais. Como esses megagrupos agem no mundo inteiro, o poder estaria diluído pelo mundo, palco da ação desses novos agentes propulsores das relações sociais e econômicas, perdendo-se, com isso, as tradicionais limitações da concepção mais clássica de poder, definido pela materialização do Estado, território e fronteiras. Dessa maneira, o imperialismo não é mais entendido como a ingerência de alguns países em outros. Evidentemente, se o Estado-nação clássico não tem mais poder para estabelecer políticas 
públicas, não pode ser apontado um país (no caso os Estados Unidos) como o responsável pela implementação de um novo projeto imperialista. Nas palavras de Negri \& Hardt (2001, p.14): "O imperialismo acabou. Nenhum país ocupará a posição de liderança mundial que as avançadas nações européias um dia ocuparam”.

O império nada mais seria do que um aparelho de descentralização e desterritorialização que incorpora gradualmente o mundo, entendido como um lócus aberto, sem fronteiras, livre para que as empresas e corporações possam conquistá-lo. O que ocorre no império nada mais é do que "a implementação de entidades híbridas, hierarquias flexíveis e permutas plurais por meio de estruturas de comando reguladoras" (ibidem).

O perigo dessas teses reside em criar um vazio na hora de apontar a maneira como se materializa a tal "desregulamentação". As observações de Perkins (2005) e Stiglitz (2002), tal como expostas anteriormente, nos revelam um componente de suma importância para entender como se instaura a supremacia das grandes empresas multinacionais. Existem, sim, uma clara articulação e identidade de interesses entre essas companhias e o governo norte-americano, como acontece, de acordo com Perkins, com a indústria petrolífera, a indústria de armamento, de construção civil e de outras corporações. Além disso, essas empresas mantêm sua sede nos Estados Unidos, país para o qual remetem, também, seus lucros. Como afirma Sader (2005, p.127), "as guerras dos EUA contra o Afeganistão e o Iraque caracterizam uma nova modalidade de imperialismo, que passa a se valer, de novo, precisamente da ocupação territorial - característica dos poderes coloniais do século XIX”.

Algumas consequências podem ser extraídas da interpretação defendida por Negri \& Hardt (2001): a desvalorização do papel do Estado, subestimação da luta política pelo poder e valorização das ações espontâneas (tipo organizações não governamentais e Terceiro Setor) contra o neoliberalismo e o modelo por ele proposto. No entanto, está muito claro, depois de ter visto as contribuições de Perkins e Stiglitz, que a hegemonia do modelo neoliberal, no âmbito planetário, nada mais representou do que a definição de princípios e lógicas destinados 
a permitir a ampliação e reprodução do capital de maneira irreversível. Praticamente todos os setores do sistema produtivo ficaram expostos à concorrência e aos embates de produtos e companhias que até esse momento tinham dificuldades para penetrar nas economias nacionais. A disputa pelas matérias-primas, o desejo de adquirir as companhias estatais e os setores de serviços, nada mais representavam do que uma etapa da evolução do capitalismo, modelo predominante no sistema mundial e que podia agir livremente, em todos os países, sempre procurando a expansão e a penetração até nos lugares mais afastados do planeta.

Pelo exposto até aqui, já podemos constatar como os autores preocupados com essa trajetória das grandes corporações deixavam entrever uma lógica própria do sistema capitalista desde sua consolidação, notadamente na Europa e nos Estados Unidos. Depois de uma acirrada disputa por produtos, matérias-primas e mercados acabaram confirmando a falsidade inerente ao mito da liberdade de mercado. $\mathrm{O}$ que aconteceu é por demais sabido e comprovado. Poucas empresas, altamente especializadas em determinados setores, acabaram predominando e impondo seu poder, seja por meio de compra dos grupos concorrentes, seja pela destruição, amparando suas atividades na predominância do seu capital. Tal processo, iniciado internamente nos países mais desenvolvidos, passou pelo domínio, de forma pouco clara como comprovaram Stiglitz e Perkins, das regiões detentoras das matérias-primas e pela internacionalização dos seus setores produtivos-chave. Não iremos nos deter em como tal trajetória ocorreu, mas, partindo dos finais da década de 1980, essa práxis ganhou contornos preocupantes por crescer sem que houvesse uma reflexão mais calma destinada a avaliar as consequências dessas novas formas de atuação dos grupos econômicos.

Por esse motivo, as abordagens mais críticas destinadas a ponderar o impacto da concentração dos meios de comunicação apontam os riscos decorrentes desse processo de oligopolização das empresas midiáticas. ${ }^{2}$ Vale a pena salientar que a comunicação é entendida como

2 No nosso estudo, tomaremos como referência os seguintes autores: Mastrini \& Becerra (2003), Moraes (2003), McChesney (2003), Ramonet (2001a, 2001b, 2002a, 2002b, 2003, 2005) e Lima (2001, 2003). 
um dos fatores importantes na construção e no aprimoramento do sistema democrático e na existência da pluralidade da informação. As abordagens dos autores estudados apontam para um quadro no qual os conglomerados da mídia estariam seguindo a trajetória já descrita anteriormente, ou seja, garantir sua presença nas diversas partes do mundo a qualquer custo, adotando, como princípio norteador das suas ações, a obtenção do lucro e o controle da informação, como veremos a seguir.

A supremacia do sistema capitalista nos moldes neoliberais, no âmbito mundial, coloca pelo menos duas grandes questões na hora de procurar entender a lógica da concentração dos meios de produção. As políticas seguidas pelos detentores dos meios de comunicação pouco diferem das políticas encontradas nos demais setores produtivos e que visam à obtenção do lucro. Efetivamente, os autores consultados (Mastrini \& Becerra, 2003; McChesney, 2003; Moraes, 2003; Lima, 2001) parecem bastante categóricos na hora de explicar o paralelismo entre as políticas adotadas pelas empresas de comunicação e as do sistema produtivo. A luta pela maximização do lucro implica os seguintes componentes: políticas internas de adoção de um sistema tecnológico de última geração, ampliação da área de atuação procurando aumentar os mercados consumidores, favorecimento de medidas destinadas a evitar custos e a procura por padronizar mercados. Essa política equivale ao que poderíamos qualificar como reestruturação empresarial e que segue os modelos mais avançados da reengenharia de produção. Essa primeira frente é facilmente identificável por se tratar de um processo essencialmente quantitativo. Nos autores anteriormente citados, uns mais voltados para o contexto global e outros para a realidade latino-americana, pode ser verificada tal trajetória.

Entretanto, por se tratar de conglomerados relacionados com a produção e veiculação de bens simbólicos, uma outra lógica emerge dentro das empresas de comunicação que não é apenas quantitativa, mas também qualitativa. Esta nos parece muito mais complexa e de difícil constatação por envolver receptores, não apenas consumidores, que podem aceitar, ou não, os produtos emanados dos conglomerados da comunicação. Não se trata de cair no mundo da subjetividade e aceitar a proposta atraente e fácil de colocar os receptores todos num 
mesmo patamar. Mesmo porque, pensando na realidade latino-americana, sua diversidade cultural e sua complexidade nas diferenças sociais colocam entraves ao processo de massificação proposto pelos conglomerados da mídia. A mesma constatação, embora de maneira bastante diferenciada, vale para a Europa ou o continente asiático. A supremacia do capital não implica, necessariamente, a hegemonia absoluta e única do modelo proposto pela ideologia neoliberal. Aqui reside, em nosso entender, a abertura de inúmeras possibilidades para poder avançar na compreensão das medidas emanadas dos grupos detentores não só dos veículos da comunicação, mas também das fontes de notícias e dos setores de entretenimento veiculados pelos meios de comunicação. A contribuição de Ramonet e do Le Monde Diplomatique nos parece de vital importância nessa questão. Porém, antes de entrar nas suas abordagens, convém resgatar a trajetória e o significado dado pelos autores anteriormente citados na concentração midiática.

Se as empresas multinacionais começaram a vislumbrar a possibilidade da concentração na década de 1970, tal como sustenta Perkins (2005), no setor midiático o processo ocorreu na década de 1990, momento no qual a tecnologia passou a fazer parte inseparável dos meios de comunicação. Nos dez anos seguintes, fruto da continuidade do desdobramento da supremacia tecnológica, o quadro das comunicações, salvo em determinados países, pode ser definido como digitalizado, desregulamentado e globalizado. As transformações provenientes da tecnologia e da transnacionalização tornaram possível a transmissão via satélite, superando fronteiras e ampliando o raio de sua abrangência. Já a globalização, tal como foi imposta pelas normas do FMI, do BM e da OMC, obrigou os Estados a reduzir investimentos, cortar subsídios e privatizar suas companhias e serviços. Assim, os serviços públicos de rádio e televisão, tradicionalmente beneficiados pela ajuda do poder público, sofreram cortes "inevitáveis", abrindo o espaço para a ação da iniciativa privada.

Ana Fiol (2001) caracteriza o processo de concentração, no âmbito mundial, como decorrente da junção dos seguintes fatores: a desregulamentação e a transnacionalização das telecomunicações, a privatização e a comercialização dos serviços públicos de rádio 
e televisão, os processos de desregulamentação e liberalização da propriedade dos meios de comunicação, a concessão de licenças a grupos multinacionais, a integração vertical e horizontal dos meios de comunicação nacionais com os internacionais, a formação de oligopólios regionais e, finalmente, a transnacionalização e a concentração das indústrias culturais, notadamente na produção e comercialização dos seus produtos.

Neste livro, privilegiaremos a relevância da comunicação e dos bens simbólicos com os quais tais grupos operam e que têm como finalidade favorecer a construção da democracia e apresentar pluralidade de versões e interpretações. De fato, estamos falando de um dos segmentos vitais no modelo neoliberal. Afinal, como lembra Robert McChesney (2003), a globalização econômica e cultural seria impossível sem um sistema de mídia comercial global para promover os mercados globais e para encorajar os valores de consumo. Compartilhando a mesma ideia, Moraes (2003) considera as corporações da mídia como instrumentos operacionais da globalização, divulgando um determinado discurso que acaba se tornando hegemônico em função da identidade existente entre as empresas comunicativas e as práticas provenientes da ideologia neoliberal. Pouco diferem as contribuições de Mastrini \& Becerra (2003). Ao centralizarem suas análises no contexto latino-americano, esses autores apontam a forte concentração dos meios de comunicação no mundo hispânico, uma vez que cinco grandes grupos seriam os proprietários dos mais diversos setores da comunicação na América Latina. Também Lima (2003) alerta para o perigo da perda de autonomia na medida em que ocorre a entrada dos grupos multinacionais na área da comunicação regional e local.

Mastrini \& Becerra (2003), concordando com as observações de Fiol, enumeram o conjunto de fatores responsáveis pela transformação no processo de concentração midiática: o salto tecnológico auspiciado pela convergência de suportes e mecanismos de distribuição na esfera da informação e da comunicação, a deterioração das empresas públicas, as estratégias de mundialização dos grandes grupos do planeta e a expansão da publicidade como mecanismo privilegiado do financiamento dessas atividades. As considerações de Mastrini 
\& Becerra (2003) encontram um claro significado em McChesney (2003). A tecnologia, notadamente a relacionada com o aumento do número de satélites e a implementação do sistema de cabo, tirou os argumentos dos defensores do monopólio estatal dos meios, uma vez que aumentou as frequências disponíveis, e, com isso, se esboçou uma grande possibilidade para a iniciativa privada se apropriar de alguns desses canais disponíveis e ociosos. O descontentamento com a programação estatal, o auge do pensamento neoliberal, a abertura dos países aos investimentos estrangeiros e a adoção da mundialização acabaram abrindo o caminho para a formação da oligopolização dos meios de comunicação. Na verdade, de acordo com Moraes (2003), abria-se a possibilidade para fazer valer uma lógica responsável pela adoção de um processo de concentração, pois as corporações seguiram políticas de produção, comercialização e de marketing em mercados geograficamente distantes, mas, agora, unidos pela supremacia mundial do pensamento neoliberal. O resultado aponta também para coincidências nesses autores. A cultura e a produção simbólica, veiculadas pelos meios de comunicação, passaram de um direito à identidade a uma simples mercadoria à venda. Isso ocorre num momento em que a aceleração dos processos tornou-se visível e presente em todos os locais do planeta de maneira instantânea e real. Ainda, para complicar mais essa trajetória, verifica-se uma forte concentração do mercado da mídia, que acabou nas mãos de pouquíssimos grupos.

O professor Venício Lima (2003), preocupado com a concentração da mídia no Brasil, adota um posicionamento semelhante ao seguido pelos autores anteriormente mencionados. Entretanto, sua contribuição aporta vários aspectos peculiares ao modelo brasileiro e, de alguma forma, latino-americano. No seu ponto de vista, a presença dos oligopólios estrangeiros não se concretizou, pois "a crise financeira na qual o setor está mergulhado afastou o investimento externo apesar do esforço de 'enxugamento administrativo' realizado por várias empresas". Contudo, isso não significa que inexista o controle dos meios de comunicação por poucos grupos, muito deles de caráter familiar. A concentração se apresenta de maneira vertical, horizontal, cruzada e em cruz. 
A vertical compreende, de acordo com Lima (2003), "a oligopolização ou monopolização que se produz dentro de uma mesma área do setor". O melhor exemplo de concentração horizontal no Brasil, afirma ele, continua sendo a televisão. Na televisão paga, segundo Lima, o grupo NET-SKY, da Globo, controla 95\% da TV por satélite.

Já a horizontal constitui-se "na integração das diferentes etapas da cadeia de produção e distribuição, quando um único grupo controla desde os vários aspectos da produção de programas de televisão até a sua veiculação, comercialização e distribuição". Para o autor, esse tipo de concentração é uma prática consolidada na televisão brasileira.

A cruzada faz referência "à propriedade por um mesmo grupo de diferentes tipos de mídia do setor de comunicações". Por exemplo: TV aberta, TV por assinatura (a cabo, MMDS ou via satélite-DTH), rádio, revistas, jornais e, mais recentemente, telefonia (fixa, celular e móvel, via satélite), provedores de internet, transmissão de dados, paging etc. Para Lima, alguns dos principais conglomerados de comunicações no Brasil se consolidaram por meio da propriedade cruzada na radiodifusão (rádio e televisão) e na mídia impressa (jornais e revistas).

Finalmente, a em cruz serve para "identificar o monopólio da reprodução, em nível local e regional, dos oligopólios da 'propriedade cruzada"”. Verificou-se que, na grande maioria dos Estados da Federação,

[...] os sistemas regionais de comunicações são constituídos por dois "braços" principais, geralmente ligados às Organizações Globo - existe um canal de televisão, largamente majoritário, quase sempre integrante da Rede Globo; e dois jornais diários, um dos quais - o de maior circulação - está sempre ligado a um canal de TV, e - quase sempre - ao canal de televisão afiliado à Rede Globo; e sempre, paralelamente, ligado a uma rede de emissoras de rádio, com canais AM e FM. Cada um desses jornais, em quase todas as capitais, reproduz as principais seções de "O Globo" e seu noticiário é alimentado, predominantemente, pelos serviços da Agência de Notícias Globo. (Lima, 2003)

A publicidade financiando a mídia aparece como uma segunda grande explicação encontrada entre os críticos do processo de concentração midiática. A relação entre a publicidade e sistema produtivo 
midiático está colocada, explicitamente, em Mastrini \& Becerra (2003), Moraes (2003) e McChesney (2003). Parece que as empresas estariam aplicando o conhecidíssimo lema de que a publicidade é a alma do negócio. Os investimentos chegam a quantias assustadoras, e, também, sem essa política, dificilmente as empresas sobreviveriam num mundo tão competitivo. A crença nesses altos investimentos reside, de acordo com Mastrini \& Becerra (2003), em que as empresas acreditam que, assim, ganhariam as preferências dos consumidores.

Pode-se aferir, em decorrência desse princípio, que o triunfo econômico é imprescindível e inerente ao funcionamento do mercado livre. Multiplicar o capital, via mercado e publicidade, supõe estar inserido e ter capacidade de competição no sistema econômico. Assim, os meios, ou melhor, o processo de concentração dos meios acabaria sendo beneficiado dentro dessa concepção econômica vigente na atualidade. Afinal, a concentração midiática oferece aos possíveis anunciantes uma ampla gama e variedade de mídias nas quais seus produtos ficarão expostos ao consumidor.

Dessa maneira, é comum encontrar propagandas de filmes em jornais e revistas do mesmo grupo. Os custos se reduzem bastante com essas práticas, e, ao mesmo tempo, as empresas se desenvolvem como corporações capazes de movimentar até $5 \%$ ou $6 \%$ do PIB de alguns países "emergentes" ou 30\% a 40\% nos mais desenvolvidos. Talvez por essa razão, Mastrini \& Becerra (2003) alertam para o processo de integração vertical e horizontal nos meios de comunicação. $\mathrm{Na}$ verdade, isso implica aceitar o controle total ou parcial dos canais de produção e comercialização por parte de um grupo reduzido de atores que, ainda, levam a uma diversificação de suas atividades em diferentes mercados. $\mathrm{O}$ desejado, com essas práticas, é entendido por McChesney (2003) como uma uniformização do mercado, por tratar-se de produtos midiáticos voltados para o consumidor.

Os enfoques anteriores criam um quadro pouco animador e bastante previsível com relação ao futuro da concentração dos meios de comunicação. Nada impede que a concentração caminhe no sentido de reduzir ainda mais o número de companhias operando no âmbito mundial. Mastrini \& Becerra (2003) vislumbram, no âmbito 
regional, como se processa essa política de concentração. Poucos grupos, regionalmente bem definidos, dominam e operam em países determinados, realizando alianças com os megaconglomerados mundiais. Lima (2003), como foi mostrado nas páginas anteriores, também projeta uma situação semelhante, embora suas preocupações residam na situação brasileira. A lógica adotada por esses grupos da mídia caminha num sentido duplo.

Inicialmente, seria necessário desregulamentar e tornar mais flexíveis as legislações existentes nos países para permitir a entrada de capitais estrangeiros nas empresas midiáticas locais. Um segundo aspecto está claramente voltado, com o apoio e a política de alianças em andamento, a ampliar sua atuação nas mais diversas áreas, impedindo a pluralidade de opções para o consumidor. Com isso, as denominadas Políticas Nacionais de Comunicação (PNC) estariam sendo derrotadas e relegadas para um segundo plano. Lima alerta para um dado significativo. Nem sempre a desregulamentação garante a presença dos grandes oligopólios, notadamente quando os grupos locais apresentam déficits significativos.

Entretanto, destacam Mastrini \& Becerra (2003), como esses serviços requerem grande domínio tecnológico, a concentração midiática latino-americana depende das alianças nesse setor com os grupos europeus e americanos. Vale a pena destacar ainda que o poder aquisitivo da população impediria a massificação desses acessos, uma vez que eles acabam sendo pagos. Assim, o grande dilema apontado por Mastrini \& Becerra reside no desafio econômico do continente para poder ter acesso a esses bens. Por essa razão, percebem como os meios de comunicação latino-americanos preservam uma certa margem de autonomia para produzir conteúdos específicos já encontrados nos próprios meios desde décadas anteriores.

De maneira bastante próxima a Mastrini \& Becerra, Dênis de Moraes (2003) vê nesse processo entraves graves e de difícil resolução, até porque a estruturação em redes, que ele denomina de intra/ inter/multissetoriais, acaba penetrando em todas as instâncias e controlando os processos decisórios, sempre dando vantagens aos países ricos em relação aos pobres. Estes, por sua vez, estariam não só do- 
minando as informações, mas também agindo de maneira muito livre por não ter responsabilidade perante as instâncias regulamentadoras de sua produção. Apenas têm compromissos com seus acionistas, o que, na prática, significa aumentar lucros. Nesse contexto, Dênis de Moraes opta por defender a retomada da discussão política sobre a mídia, democratizar no âmbito mundial sua atuação, fortalecer os grupos contra-hegemônicos e usar as novas tecnologias para combater suas ações. Todo esse processo deveria ser acompanhado do fortalecimento da esfera pública, fórum privilegiado para construir um sistema mais aberto e efetivamente democrático. Com bastante clareza, enxerga essa atuação não mais no âmbito local, e, sim, mundial, pois de nada adiantariam ações promovidas por países ou grupos isolados, uma vez que as grandes corporações agem mundialmente.

Na crítica ao processo de concentração das empresas midiáticas, McChesney (2003) adota uma postura bastante dura e taxativa. Não aceita a supremacia do modelo neoliberal como um sistema estável, mas, sim, como um processo que concentra capital. Sem a democratização do capital, a própria desigualdade promovida favorece uma minoria detentora do poder econômico. Acreditando na instabilidade, McChesney vê conflitos claramente direcionados no sentido de criticar as desigualdades e injustiças provenientes de tal modelo. Se o neoliberalismo apostou na despolitização do mundo, o que se percebe é justamente o contrário. A realidade econômica e a situação de pobreza em que vivem a maioria das pessoas estariam gerando um movimento global de descontentamento e de condenação de tais políticas.

Nessa direção conspirativa e reivindicatória dos marginalizados da globalização, observa-se, de acordo com McChesney, a discussão, pela primeira vez, do papel da mídia e de sua influência no âmbito mundial. A tendência não ficaria restrita ao âmbito da discussão, mas, sim, ao da criação de canais alternativos com natureza mais democrática e que não visariam, apenas, aos fins lucrativos, tal como ocorre com a mídia comercial. Esse movimento é entendido como necessário para poder ter sucesso na luta pela existência de uma mídia democrática.

Ignacio Ramonet (2005) segue a trajetória descrita pelos autores citados anteriormente. Entretanto, sua abordagem relacionada com 
a concentração da mídia sugere alguns pontos que, no nosso entender, adquirem relevância significativa. Num texto bastante curto, mas nem por isso menos importante, Ramonet avança no sentido de relacionar os processos de concentração dos grandes grupos midiáticos com outros setores como eletricidade, informática, armamento, construção, telefonia e da água. Assim, a junção de empresas envolvendo os vários segmentos faz que Ramonet veja nesse ato uma clara predominância da atuação do capital fundamentado na supremacia do mercado. A luta constante pela obtenção do lucro resulta, no mínimo, no fim de alguns valores considerados por ele fundamentais, dentre eles, o direito do cidadão de estar bem informado.

O exemplo mais ilustrativo, sustenta Ramonet (2005), ocorreu nos Estados Unidos, onde as regras contra a concentração do audiovisual foram abolidas em fevereiro de 2002.

A América Online tornou a comprar a Netscape, a revista Time, a Warner Bros. e a cadeia de informação CNN; General Electric, a maior empresa mundial pela sua capitalização em bolsa, apossou-se da rede NBC; a Microsoft de Bill Gates reina sobre o mercado de softwares, quer conquistar o de jogos eletrônicos com o seu console X-Box e, através da sua agência Corbis, domina o mercado do fotojornalismo; a News Corporation de Rupert Murdoch, tomou o controle de alguns importantes jornais britânicos e americanos (The Times, The Sun, The New York Post), possui uma rede de TV por satélite (BskyB), uma das cadeias dos Estados Unidos (Fox), além de uma das principais produtoras de filmes (20th Century Fox).

Na França, país no qual reside Ramonet, a crise da publicidade e de vendas por assinatura ocasionou a passagem do controle dos meios de comunicação para grupos ligados à indústria bélica, notadamente o Dassault e Lagardère, que têm em comum a particularidade de serem constituídos em torno de uma empresa central cuja atividade é militar (aviões de caça, helicópteros, mísseis, foguetes, satélites...). Como o próprio Ramonet (2005) sugere: 
O medo está então realizado: algumas das maiores mídias estão, a partir de agora, nas mãos dos mercadores de canhões... Na hora das tensões com o Iraque, pode-se supor que estas mídias não se oporão com verdadeira energia a uma intervenção militar contra Bagdá...

De maneira bem mais detalhada, Ignacio Ramonet (2002b), no lançamento da edição espanhola on-line do Le Monde Diplomatique, apresentou as ideias predominantes no sistema de informação, num mundo dominado pelos conglomerados da mídia. Inicia sua arguição com um posicionamento taxativo: a imprensa está em crise. Tal afirmação se assenta numa abordagem detalhada das transformações operadas recentemente na concepção do que se entende por informação. Para Ramonet, quatro fatores teriam corroborado a descaracterização da informação, função primordial na profissão do comunicador social, responsável pela formação de qualidade do cidadão.

O primeiro está relacionado à própria ideia de informação. Antes da tal crise por informação, entendia-se a descrição precisa e documentada do fato a ser publicado. Além disso, as empresas de comunicação precisavam subsidiar o receptor com dados suficientes para que este compreendesse seu significado mais profundo. Perguntas-chave, como quem fez o quê, com que meios, onde, por que e quais as consequências, deveriam ficar totalmente esclarecidas para o leitor. Para Ramonet, o advento da televisão, e sua supremacia como meio de comunicação, implicou um duro golpe naquela concepção antiga de informação. A razão dessa transformação reside no fato de se poder assistir ao vivo, em tempo real, praticamente a tudo o que acontece. Com isso, a reflexão e as explicações passaram para um segundo lugar ou simplesmente foram abandonadas. Para estar informado, é necessário apenas ver o acontecimento, não entender seu significado.

Outro ponto abordado por Ramonet refere-se à tirania do tempo presente vivenciado na contemporaneidade. A televisão torna-se, novamente, o alvo de suas críticas. Aceitando como verdadeiro o item anterior, podemos concluir que o tempo presente está determinado pela imagem. Efetivamente, na hora de selecionar os fatos para serem publicados na imprensa escrita, imperam os que possuem imagens, 
e, consequentemente, o resto das notícias fica num segundo lugar, quando não são ignoradas. A televisão, num mundo de clara predominância visual, estaria ditando as regras ao jornalismo impresso. As notícias que não aparecem na TV perdem sua importância, mesmo que algumas sejam mais relevantes que aquelas vistas e aceitas pelo público como verdadeiras. Dessa forma, a imagem determina a informação na atualidade.

O tempo da informação aparece como outro fator a ser considerado. Para Ramonet, a informação hoje se resume ao que pode ser comunicado ao vivo, em tempo real. Quando um fato chega ao leitor, normalmente é considerado ultrapassado, e o potencial de avaliação e reflexão que poderia provocar encontra já um público "informado". De alguma maneira, no jornalismo, a entrada de fotos coloridas e a transformação visual da primeira página, valorizando as manchetes e as notícias breves, representam uma tentativa de adequação a essa predominância do público das imagens. ${ }^{3}$ Com isso, o espaço anteriormente destinado à exposição de opiniões e análises no jornal impresso cedeu espaço para as imagens e as notícias resumidas.

O quarto componente apresentado por Ramonet diz respeito à veracidade da informação. Na atualidade, um fato é considerado verdadeiro não por terem sido aplicados critérios objetivos, rigorosos ou porque as fontes tenham sido devidamente verificadas. A veracidade se impõe pela repetição constante e permanente de dados nem sempre confirmados. Como estamos num momento de alta competitividade, a mesma notícia veiculada pela televisão, pelo rádio e pelo jornal torna-se verdadeira. Se a isso se acrescenta a deficiência dos meios de comunicação em avaliar as estruturas, chega-se a uma situação na qual imperam o simplismo e a superficialidade.

3 Esse processo chegou até o Le Monde, grupo majoritário que financia o Diplomatique. Em janeiro de 2002, o Le Monde reformulou seu projeto gráfico inserindo fotos coloridas nas suas páginas e adotando outras alterações que o tornaram um jornal igual aos seus concorrentes. Ainda decidiu colocar na bolsa parte de suas ações no sentido de captar recurso para saldar as altas dívidas do jornal. Isso chegou a pôr em dúvida a decantada autonomia do Le Monde Diplomatique, mas até a presente data os acionistas não interferiram na linha editorial do Diplô. 
A soma desses fatores constitui o que Ramonet citava como crise dos meios de comunicação. Neles, prevaleceriam a repetição, a imitação, o plágio e a formatação padronizada. Informação e comunicação tendem a ser equivalentes, quando em outros momentos possuíam características bem diferenciadas. Ramonet denomina essa situação de "censura democrática", ou seja, o poder do sistema de manipular os meios fornecendo-lhes as mesmas versões e imagens. Aparentemente, aceita-se o sistema democrático como o mais válido e representativo, mas a capacidade da crítica fica diluída dentro dos limites "verdadeiros" estabelecidos por esse sistema. O excesso de democracia geraria a apatia, recaindo no público, preso por essa rede de facilidades provenientes das novas tecnologias e da ausência da crítica.

Nesse pano de fundo, a relevância do Le Monde Diplomatique (Diplô), jornal do qual Ramonet foi diretor, sobressai por detectar, abordar e denunciar temas decorrentes da concentração dos meios de comunicação de massas. Apenas para ilustrar, apontamos o que diz respeito ao fim da diversidade via publicidade. Para o Diplô, a publicidade e os mecanismos por ela usados devem se inserir dentro do contexto no qual se desencadeia o processo da denominada supremacia do modelo neoliberal. Nele, a publicidade cria valores falsos como o mito do tempo livre, da permissividade e da flexibilidade das estruturas sociais. Evidentemente, a publicidade oculta os problemas decorrentes do neoliberalismo: a despolitização, o empobrecimento constante dos trabalhadores, a disponibilização absoluta do ser humano ao sistema produtivo e a tendência à homogeneização dos comportamentos e das atitudes das pessoas via programas produzidos e organizados pelas indústrias culturais. Dessa maneira, sugere Ramonet, a sociedade caminha, via projetos de marketing e publicidade, para a consolidação de um quadro pouco animador.

A publicidade teria a finalidade de despertar os desejos de consumo. Por essa razão, o Diplô insiste que a publicidade não pode ser entendida, apenas, como uma forma de divulgação dos produtos, mas, sim, como uma forma de investimento realizado pelos grandes grupos econômicos inseridos dentro da nefasta lógica neoliberal de ter que completar o ciclo econômico produção-consumo, como forma 
de reproduzir seu capital. Além de ser um instrumento de divulgação e de venda, teria que despertar e manter o desejo constante do consumo, sem o qual as empresas não poderiam sobreviver dentro de um mundo globalizado e competitivo.

Bernard Shiegler (2004) descreve esse processo como o limite extremo da relação produção-padronização do consumidor. De maneira lapidar, ele defende que a mundialização do sistema produtivo, bem como seu planejamento e sua implementação via novas tecnologias, serviria para dominar o tempo livre dos trabalhadores/consumidores. Ao comercializar o tempo livre, a indústria cultural desenvolve uma dupla função: controlar intimamente os comportamentos individuais e obter recursos, via venda de mercadorias expostas aos consumidores, para financiar as próprias indústrias. Assim, o poder do capitalismo contemporâneo repousa sobre o controle simultâneo da produção e do consumo que regula as atividades das massas.

Para Shiegler, o século XX otimizou as condições e a articulação da produção e do consumo, com as tecnologias de cálculo e da informação para o controle da produção e do investimento, e com as tecnologias da comunicação para o controle de consumo e dos comportamentos sociais, inclusive políticos. Dessa vez, a grande ilusão não é mais a "sociedade do lazer", mas a "personalização" das necessidades individuais.

Sem dúvida, essa é a diferença fundamental entre a proposta do Le Monde Diplomatique e os autores mais preocupados com a forma como aconteceu a concentração da mídia. Ramonet e o jornal do qual ele foi diretor, o Diplô, estariam já denunciando e provando aquilo que outros autores apenas vislumbravam como possibilidade. Como se materializa, concretamente, essa opção realizada pelos meios na elaboração de suas notícias é o tema a ser tratado no capítulo seguinte, tomando como objeto de estudo os episódios de 11 de setembro. Pela repercussão e pelos desdobramentos emanados desses eventos, merecem um estudo mais detalhado, como pretendemos realizar nas páginas seguintes. 


\title{
7 \\ Estudo dE CASO: O 11 DE SETEMBRO \\ DE 2001 NA VEJA E NO \\ Le Monde Diplomatique
}

\author{
"Quem responde com pressa, raramente \\ acerta."
}

(Provérbio árabe)

Para testar as possibilidades de junção da história e da comunicação, elaboraremos uma análise sobre os atentados de 11 de setembro de 2001. A maneira como dois meios de comunicação impressos apresentaram o fato para seus leitores servirá de referência para estudar o modo como abordaram esses trágicos episódios. A revista Veja e o jornal Le Monde Diplomatique foram os objetos de estudo. A escolha não é aleatória. $O$ fato em questão repercutiu amplamente neles a ponto de elaborarem números especiais para interpretar esse acontecimento. A revista Veja, na semana seguinte ao 11 de setembro, publicou um número especial sobre o que denominou de atentado terrorista. O Le Monde Diplomatique, jornal mensal, no mês de outubro reservou amplo espaço para apresentar sua versão sobre esse episódio.

Sabidamente, os dois meios seguem linhas editoriais diferentes, o que já faz pressupor a existência de abordagens díspares para justificar suas versões. Esse será um dos objetivos do atual estudo. Entretanto, a questão principal, além de identificar e caracterizar as versões 
oferecidas, reside na identificação dos recursos e mecanismos usados para construir as notícias lidas pelo público desses meios. Partimos do pressuposto de que as mensagens tornadas públicas repercutem na sociedade e ajudam na construção de sentido entre seus receptores.

As considerações esboçadas nos capítulos anteriores serão levadas em consideração. Inicialmente, é necessário conhecer os dois grupos comunicacionais, procurando identificar seu posicionamento político e a linha editorial seguida na apresentação das suas matérias. Para isso, servimo-nos das informações oficiais, sem esquecer algumas das críticas encontradas contra os dois meios de comunicação. Tais críticas representam um dos indicadores importantes para definir a linha editorial seguida por cada produto estudado. Após essa identificação, as matérias escritas ocuparão as nossas análises.

Fundado em 1950, por Victor Civita, o Grupo Abril, no momento da escrita deste texto, é presidido por seu filho Roberto Civita. Empregava, em 2007, mais de 7.400 pessoas. Naquele ano, a Editora Abril publicou 314 títulos, dos quais 127 regulares e 187 edições one shots e especiais, além de ser líder nos vários segmentos da comunicação e entretenimento em que opera. Em um ano, suas publicações têm uma circulação de 163,8 milhões de exemplares, em um universo de mais de 22 milhões de leitores e 3,8 milhões de assinaturas. Sete das dez revistas mais lidas do país são da Abril, sendo Veja a quarta maior revista semanal de informação do mundo e a maior fora dos Estados Unidos. ${ }^{1}$ De fato, essa revista pode ser considerada o símbolo do grupo e carro-chefe do Grupo Abril, pelo viés político ou comercial.

Falando sobre ela, seu atual diretor, Roberto Civita, não esconde que a linha editorial da revista acredita piamente na economia de mercado, e seu conteúdo é exposto de forma clara e simples. Assim, explicam-se as acusações abertas e diretas a governos planificados e socialistas, caso de Venezuela e Cuba. A publicação trata de movimentos sociais, como no Fórum Social Mundial, simplesmente rotulando-os de vagabundos, comunistas, terroristas, baderneiros

1 Concretamente, esses números se encontram no site do grupo. 
ou guerrilheiros, como se pretendessem banir algo dos meios de comunicação do país (Soares, 2005).

O Grupo Abril fornece informação, cultura, educação e entretenimento para praticamente todos os segmentos de público e atua de forma integrada em várias mídias. O Grupo é composto pela Editora Abril (revistas), Abril Digital (que reúne Abril.com e Abril no celular), FIZ TV e Canal Ideal (TVs segmentadas), TVA (parceria estratégica com a Telefônica), além das editoras Ática e Scipione (Abril Educação). Possui, ainda, a maior gráfica e distribuidora de revistas da América Latina e um eficiente serviço de assinaturas.

Muitas denúncias pairam sobre os Civitas e a forma como obtiveram todo esse império gigantesco. Apenas para ilustrar, reproduzimos as mais significativas. Na década de 1980, uma Comissão Parlamentar de Inquérito (CPI) agitava o Congresso Nacional. A investigação tinha como foco a compra pelo Grupo Abril de dois terrenos, em Salvador (BA) e São Luís (MA), para a construção de hotéis Quatro Rodas. Os governadores dos Estados em questão eram, à época, Antônio Carlos Magalhães (ACM) e José Sarney, respectivamente. Ambos doaram belíssimos parques para a construção dos hotéis, sob a condição de que estes fossem parcialmente conservados. Pouco depois, o Grupo Abril, comandado por Roberto Civita, vendeu os hotéis à multinacional espanhola Sofitel. Mas só vendeu os hotéis. A parte conservada dos parques ficou em posse de Civita, que os loteou, construindo centenas de casas no local.

A denúncia é de Sebastião Nery, jornalista da Tribuna da Imprensa, confirmada pelo atual governador do Paraná, Roberto Requião, em discurso no Congresso Nacional, em setembro de 1999, quando ainda era senador pelo PMDB. O gesto de ACM parece ter-lhe garantido um bom trânsito na empresa de Civita, tal como pode ser visto no artigo do jornalista Cláudio Júlio Tognolli na revista Caros Amigos (dezembro de 2003). Tognolli revela alguns detalhes - não divulgados pela grande mídia - da Operação Anaconda, que resultou na prisão do juiz João Carlos da Rocha Mattos, acusado de venda de sentenças, juntamente com outros integrantes do Judiciário brasileiro. No seu relato, ele conta que, em 1988, então repórter da 
revista Veja, publicaria 1.017 nomes de ilustres brasileiros, acusados de lavagem de dinheiro. O repórter, então, é jurado de morte por Rocha Mattos, que tinha ligações com os acusados. Resultado: um telefonema do sogro de Mattos para a direção da Veja impediu a publicação da matéria.

Roberto Requião, no entanto, não se limitou a repetir as denúncias de Sebastião Nery. Ele contou aos senadores que, assim que assumiu o governo do Paraná, em 1990, abriu processo contra o Banco Bamerindus, presidido por José Eduardo de Andrade Vieira, por danos causados ao patrimônio público do Paraná. Entretanto, não levou a questão a público. Roberto Civita ficou sabendo do processo e passou a procurar Requião para saber mais detalhes, insistindo que o assunto deveria ser tornado público pela sua gravidade. Requião cedeu e Civita enviou quatro jornalistas para investigar o caso. Requião acreditou que a Veja, depois de concluídas as investigações e ter obtido dados importantes, revelaria o caso.

Dias depois, ainda antes da publicação da matéria, e já duvidando da concretização da publicação pelo fato de o Bamerindus ser um dos principais anunciantes da revista $V e j a$, Requião recebe um telefonema de Civita, que teria dito o seguinte: "Governador, compre a próxima Veja e o senhor verá o que é uma revista independente". Requião comprou. Mas o que viu foram seis páginas de propaganda do Bamerindus. Nenhuma linha sobre o caso fora publicada. As informações obtidas por Roberto Civita serviram, de acordo com o relato de Requião, apenas para chantagear o Bamerindus, que teve sua propaganda estampada na revista por mais de seis meses. Para Roberto Requião, restou ser criticado pela revista quando se posicionou contra a liberação do plantio e comércio de transgênicos no Brasil, na edição 1826 da revista, sendo chamado de "governador caça-manchetes".

Outro exemplo de posições políticas "duvidosas" diz respeito ao episódio no qual o Grupo Abril obteve um empréstimo milionário, em 1976, depois que acusou Mino Carta, na época diretor de redação da revista Veja, de ter um posicionamento crítico em relação ao regime militar, isentando a revista da acusação de ser contra a situação vigente no país. Depois da demissão de Mino Carta, o empréstimo 
foi concedido pela Caixa Econômica Federal e a revista mudou radicalmente seu posicionamento político (Costa, 2005).

O Le Monde Diplomatique (Diplô, como é mais conhecido entre seus leitores) apareceu pela primeira vez na França, em 1954, como um suplemento mensal do jornal Le Monde. Aos poucos, foi ganhando autonomia até ser, na atualidade, uma empresa subsidiária do grupo Le Monde. Nessa evolução, o Diplô procurou autonomia, o que resultou numa composição bastante original, totalmente diferente daquela encontrada nos meios comerciais.

Os leitores e assinantes do Diplô, por meio da Associação dos Amigos do Le Monde Diplomatique, têm uma participação de 24\% do capital acionário do jornal e os jornalistas detêm $25 \%$ das ações, por meio da Association Günter Holzmann - nome alusivo ao ex- militante antinazista que doou os recursos necessários à operação. Esses 49\% são bem mais do que o suficiente para formar uma "minoria de bloqueio", que, segundo a legislação francesa, sede oficial desse jornal, é de 33,34\%. Assim, nenhuma decisão estratégica pode ser tomada sem o apoio dos leitores e da redação. Embora o grupo Le Monde seja o acionista majoritário, não intervém na linha editorial do Le Monde Diplomatique, pelo menos até o presente momento. ${ }^{2}$

Atualmente, o Le Monde Diplomatique desdobra-se em sessenta edições internacionais, dentre as quais metade impressa e outra metade on-line. A marca das 32 versões no ar foi atingida só no final de outubro de 2006. A maior parte dessas edições on-line corresponde a uma versão eletrônica da edição impressa. Nelas se opera um trabalho de tradução das matérias que chegam aos leitores via internet. Outras, entretanto, são independentes - a exemplo do Brasil, Japão e da República Tcheca, sem esquecer as edições em catalão (produzida em Andorra), chinês (feita na França) e esperanto (editada em Cuba).

A estratégia do Diplô carrega, sobretudo, o sonho de um mundo diferente, e mais especificamente sua atuação se centra em combater o neoliberalismo e todas as suas manifestações e desdobramentos.

2 Informações obtidas em "Pensamento Crítico \& Alternativas". Disponível em: $<$ www.diplo.com.br>. Acesso em: 20 jan. 2000. 
Essa abertura ao mundo não é de ontem. Muito cedo, o Le Monde Diplomatique pretendeu ser um jornal internacional. Nos anos 1970, após a queda das ditaduras em Portugal e na Grécia, as edições do Le Monde Diplomatique passaram a circular nesses países. Elas foram historicamente as primeiras a difundir no exterior análises da política internacional. Nos anos 1980, o jornal selou outras parcerias para além de suas fronteiras: nasceu um Diplô em espanhol, produzido, em primeiro lugar, no México, depois (em seguida ao assassinato de seu editor Yvan Menéndez, em 1986) em Buenos Aires, e finalmente em Madri. Em seguida, surgiu uma versão trimestral em árabe, produzida na Tunísia de 1987 a 1998, quando foi transferida - por um tempo - para Beirute. Uma efêmera edição em húngaro foi criada em 1991.

A partir da metade dos anos 1990, começa uma segunda onda de internacionalização, agora maior e mais durável. É dessa época que datam as duas primeiras grandes edições do Diplô, que em 2007

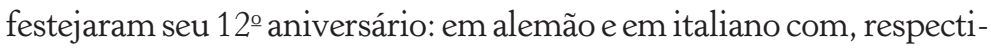
vamente, os jornais Tageszeitung (Berlim) e Il Manifesto (Roma). Um pouco mais tarde, o Diplô se estenderia, em espanhol, até Madri, com as edições L-Press, depois, Cybermonde, e com a edição do Cone Sul, em Buenos Aires. Em português, associou-se com a editora progressista Campo da Comunicação, e em grego, com o jornal Eleftherotypi.

À medida que se expandiram, as diferentes versões evoluíram. As primeiras contentavam-se em traduzir os artigos da edição francesa. Essa fórmula prevaleceu durante todo o tempo em que o Le Monde Diplomatique constituiu um suplemento encartado em jornal diário ou em uma revista semanal que já tratava da atualidade nacional e regional. Mas, quando ele tomou a forma de um veículo mensal independente, seus responsáveis sentiram naturalmente a necessidade de agregar artigos originais para responder às expectativas específicas de seus leitores. Para que essas inclusões não comprometessem a responsabilidade de Paris, eles eram assinados pela "nossa redação local", fórmula bastante sutil de dissipar e evitar críticas diretas aos jornalistas responsáveis pela elaboração das matérias.

Inspirada por um problema pragmático, essa maior flexibilidade acelerou o crescimento do número de edições impressas: havia cinco 
no final de 1996 (com uma tiragem total de 500 mil exemplares), seis no final de 1997, sete no final de 1998 (a tiragem atingiu 700 mil exemplares), dez no final de 1999, 13 no final de 2000 (a marca de 1 milhão de exemplares tinha sido atingida), 16 no final de 2001, 22 no final de 2003, 25 no final de 2004 (para 1,5 milhão de exemplares), 27 no final de 2005 e 32 em outubro de 2006.

O Le Monde Diplomatique envolveu-se, no plano intelectual, em todas as campanhas que marcaram a emergência da sociedade civil planetária. Em 1997, ao descrever as consequências sociais dramáticas das crises financeiras asiáticas, propôs, como antídoto, a mobilização internacional dos cidadãos contra a ditadura dos mercados - num texto que viria a estimular a fundação do movimento da Associação para a Taxação das Transações Financeiras para a Ajuda aos Cidadãos (Attac). ${ }^{3}$ Em 1998, seus artigos sobre o Acordo Multilateral sobre Investimentos (AMI) estimularam uma resposta mundial que evitou um novo ataque aos direitos sociais e ao meio ambiente. Em 1999, apontou os riscos de mais uma rodada de "liberalização" do comércio promovida pela OMC e viu nos protestos de Seattle (EUA), que desfizeram a ameaça, um sinal da "emergência de um contrapoder mundial”. Em 2000, a redação do jornal foi o local onde um grupo de brasileiros apresentou, pela primeira vez, a ideia de organização de um Fórum Social Mundial.

O Le Monde Diplomatique só pôde desempenhar um papel tão destacado na construção de uma cidadania planetária porque sempre recusou a condição de panfleto e procurou garantir sua autonomia financeira, tal como víamos anteriormente. Num mundo em que se proclama a inexistência de alternativas - e se procura, portanto, reduzir os cidadãos a espectadores da história -, nada mais transfor-

3 Originalmente, a Attac tinha a finalidade de instituir um imposto sobre movimentações financeiras internacionais (taxa Tobin) destinado a prestar ajuda a países e populações com maiores dificuldades financeiras. Posteriormente, a Attac ampliou sua área de atuação para os estudos e a intervenção contra as consequências originárias da globalização financeira mundial. Monitora, seguindo essa lógica, as decisões do Fundo Monetário Internacional, da Organização Mundial do Comércio, entre outras instituições relacionadas com a economia global. 
mador que valorizar e construir, na prática, o direito à informação, à comunicação, ao exercício de enxergar o mundo e influir em seus destinos. Essa seria a ideia central norteadora de sua atuação.

O jornal Le Monde Diplomatique Brasilé uma iniciativa conjunta dos institutos Paulo Freire e Pólis. Cabe ao Instituto Paulo Freire a responsabilidade pela edição eletrônica, e ao Pólis, a edição impressa. A edição brasileira recupera mais de 1.700 textos publicados desde 2001. Mas vai muito além. Todos os artigos foram cuidadosamente catalogados e associados a palavras-chave. A partir desse esforço, surgiu uma biblioteca no endereço http://www.diplo.uol.com.br com mais de 500 fichas temáticas, disponibilizadas para consulta gratuitamente. Elas constituem um material valioso para estudar a globalização e as alternativas contrárias ao modelo neoliberal. Cada uma reúne um conjunto de textos do jornal que permite compreender um tema-chave estudado minuciosa e criticamente pelo Diplô.

A edição eletrônica traz também, na seção "Primeira Página", dossiês especiais. Eles oferecem ao leitor artigos publicados em números anteriores do jornal - mas que conservam enorme atualidade. Cada dossiêé apresentado por um texto produzido pela redação brasileira, que atualiza as informações e as associa a fatos recentes e relevantes.

A edição eletrônica de Le Monde Diplomatique é regida pelos princípios do conhecimento compartilhado (copyleft), que visam estimular a ampla circulação de ideias e produtos culturais. A leitura e a reprodução dos textos são livres, no caso de publicações não comerciais. A única exceção são os artigos da edição mensal mais recente, acessíveis no menu lateral esquerdo do site. A citação da fonte sempre é obrigatória nesse tipo de publicação. ${ }^{4}$

4 Ao adotar essa política de publicação, o Le Monde Diplomatique se associa às tentativas mundiais de disponibilizar o conhecimento por considerá-lo um bem comum, portanto livre de qualquer interesse econômico. Essas organizações sem fins lucrativos têm crescido nos últimos anos, permitindo que regiões e cidadãos do mundo inteiro possam usufruir do acesso à informação. Particularmente, não só concordamos com essa política, como também apoiamos o Observatório da Cibersociedad, entidade destinada a defender a democratização das novas ferramentas tecnológicas como forma de lutar pela democracia comunicacional e liberdade de expressão. Mais informações sobre as licenças de conhecimento compartilhado podem ser obtidas na página brasileira da Creative Commons. 
O site do jornal é alimentado pelo sistema de publicação SPIP, baseado em Linux, gratuito e escrito em código aberto - portanto, modificável. Com ele, qualquer organização ou pessoa pode administrar e atualizar instantaneamente, e de qualquer parte do mundo, espaços complexos na internet. Também é possível organizar redes de publicações. Graças ao princípio RSS e à linguagem XML, já incorporados ao sistema, todos os textos publicados por qualquer site integrante da rede podem ser anunciados automaticamente em todos os demais.

Ao adotar uma linha editorial clara contra a globalização e o neoliberalismo, o Le Monde Diplomatique vem recebendo críticas relacionadas à forma como aborda e defende determinados posicionamentos, afetando a isenção que se espera no jornalismo. Algumas matérias mais sensacionalistas, publicadas no calor da hora, comprometem sua credibilidade. Um caso bastante significativo diz respeito à forma como esse jornal tratou o resultado das eleições de 2002 no Brasil. As premissas de sua exaltação exagerada em relação à vitória de Lula e aos possíveis desdobramentos desse resultado político para toda a América Latina não se cumpriram, o que originou a retratação pública em outros artigos, pouco tempo depois, criticando os rumos que o país seguia sob o comando de Lula. Ainda se critica o financiamento oficial fácil, obtido pelo jornal, de empresas estatais de determinados governos, o que faz pensar que seu posicionamento também implica um alinhamento ideológico em defesa de determinados governos e governantes. Finalmente, um dos questionamentos mais pontuais se direciona ao preço e público-alvo do Diplô. Esse jornal está fora de cogitação para as classes mais populares em razão do conteúdo complexo das matérias e do alto preço da venda. ${ }^{5}$

5 O preço do exemplar impresso, no Brasil, é de $\mathrm{R} \$ 8,00$. A assinatura anual de 12 números está, na atualidade (ano de 2008), em torno de $\mathrm{R} \$ 80,00$. Seu ex-diretor, Ignacio Ramonet, justifica esses preços alegando que obter informações fora do circuito das agências de notícias custa muito caro. Na maioria das vezes, o próprio jornal tem que custear as viagens de repórteres para países distantes. De qualquer forma, ele sustenta que o lucro não existe e que o capital do Diplô provém de seus assinantes, que, dessa maneira, também são proprietários (informações obtidas com o próprio Ramonet). 
Feitas essas considerações, passamos a analisar, mais detidamente, a apresentação realizada por esses dois meios da mesma notícia. $\mathrm{O}$ caso em questão envolve um acontecimento relevante, o denominado "ataque terrorista" ao World Trade Center, ocorrido em 11 de setembro de 2001. Os veículos estudados serão o Le Monde Diplomatique e a revista Veja. ${ }^{6}$ A pretensão final consiste em mapear interpretações e versões para, finalmente, tecer algumas considerações nessa tentativa de aproximação entre a história e a comunicação.

A revista Veja, já na capa, manifesta seu posicionamento com relação aos acontecimentos de 11 de setembro (Anexo 1). Ocupando quase dois terços da página, aparecem, no lado direito, as torres gêmeas envolvidas em chamas e a fumaça cobre parcialmente o nome da própria revista. Na margem esquerda, de maneira bem visível, podem ser lidas as seguintes frases: "Os americanos prometem acabar com os países que abrigam terroristas", "A perícia dos pilotos suicidas", "Ocidente x Oriente: o choque de civilizações", "A cultura do apocalipse entre os americanos", "As raízes do terrorismo islâmico" e "O medo da recessão mundial".

O número especial de Veja dedica amplo espaço para identificar os terroristas e avaliar seus novos métodos de ação. Nas páginas iniciais, as páginas amarelas, Ian O. Lesser, especialista em terrorismo e consultor da CIA e do Departamento de Estado americano durante o governo Bill Clinton, reforça ainda mais a imagem da capa. Frases como "o terrorismo está em todas as partes e ninguém, nem pessoa nem país estão livres de ser a próxima vítima” alimentam uma visão catastrófica do acontecimento. O Brasil, dentro desse contexto, em teoria, não estaria livre de ser alvo desses grupos terroristas. Tais afirmações aumentam desproporcionalmente o clima de terror. Ainda usando a fala desse especialista, Veja anuncia tempos novos e concepções novas do fenômeno do terrorismo. Efetivamente, as ações desses grupos ligados ao novo terrorismo se caracterizam pelo

6 Os números consultados foram, respectivamente: Le Monde Diplomatique, ano 2, n.1, out. 2001. Disponível em: <http://diplo.uol.com.br/2001-10,r21>. Acesso em: 15 fev. 2008. 
enorme número de vítimas fatais, por ataques a alvos simbólicos, ações suicidas, demora em assumir a autoria e por não possuir um objetivo político preciso (sic) (Veja, 2001, p.14).

Obviamente, a nova configuração exige um novo tratamento. Por esse motivo, a revista reserva amplo espaço em suas páginas para tentar defender a necessidade de se elaborar uma rede internacional de combate ao terrorismo, pois se esperava que a resposta americana, dura e implacável, levaria os terroristas para outras partes do mundo, o que implica aceitar um clima de insegurança total universal. Surpreende que, na entrevista realizada com Lesser, algumas afirmações não sejam questionadas (lapso do entrevistador ou marca intencional da revista?). Um bom exemplo é a afirmação seguinte:

Veja: O milionário Osama bin Laden pode ser considerado o terrorista mais perigoso do planeta?

Lesser: É possível que sim. Mas não podemos esquecer que estamos tratando de redes. O nome de bin Laden pode até estar no centro da rede, mas não é só ele. Acabar com bin Laden poderá ser bom, mas não resolverá o problema do terrorismo. (Veja, 2001, p.15)

Sublinhamos parte do último período pelo seu significado. Fala-se em acabar com (assassinar?) uma pessoa que, pelo menos até o momento da edição, não tinha reconhecido seu envolvimento no episódio, fato esse lembrado nas páginas seguintes, o que significa adotar procedimentos parecidos aos utilizados pelos próprios terroristas. Surpreende o silêncio do entrevistador por não questionar essa afirmação e não pensar na possibilidade do uso da lei e das convenções internacionais para solucionar esses problemas. Aceitar a morte dessa maneira interfere no público leitor no sentido de simplificar os acontecimentos. Ora, se alguém destrói, que ele seja destruído. Essa postura acabaria com o terrorismo.

A relação dos países terroristas com os Estados Unidos é apresentada como fruto de um ódio que não se explica de onde pode provir. O especialista em terrorismo prevê um cenário no qual os Estados 
Unidos avaliarão as demais nações pela política de combate a esses grupos extremistas. Apenas essas considerações e o teor das perguntas realizadas já sugerem uma tomada de posição prévia diante do fato estudado. Esse procedimento fere totalmente as normatizações dos códigos de ética e a deontologia da profissão. $\mathrm{O}$ amplo espaço das páginas amarelas, amplo se comparado com o das outras matérias, serve para fortalecer uma opinião ainda se servindo de alguém que teoricamente vivenciou de perto os atentados, ou seja, o entrevistado estava diretamente influenciado pelo que ouviu ou leu a respeito. ${ }^{7} \mathrm{~A}$ opinião de especialistas alinhados com o posicionamento da revista reforça e legitima sua versão.

De fato, além das fotos da capa, que já insinuam uma tragédia, Veja abre espaços para descrever detalhadamente o sofrimento das pessoas em decorrência do ataque. Histórias de horror e pânico desfilam pelas páginas sempre muito bem ilustradas por fotos coloridas e mapas, mas pobres em textos. Praticamente três quartas partes das páginas são tomadas pelo projeto visual, destacando cenas de desastres (ruínas, escombros, pessoas feridas, nuvens de poeira). As manchetes colocadas estrategicamente no centro e na parte superior da página dão mais força à noção da calamidade: "Este mundo nunca mais será o mesmo", "A descoberta da vulnerabilidade", "Mergulho fatal", "Nova York em chamas", "Horas de pavor, morte e destruição", "A dor da perda", "Terra arrasada", "A favor do terrorismo", "Assassinos identificados", "Terra devastada", "Em busca da resposta”, "A morte no fogo, num salto ou no desabamento", "Sem saída", "O terror ataca o golpe na fortaleza americana", "O inimigo número 1 da América”. Percebe-se nitidamente o uso de termos ligados a desastres, sempre bem destacados e ocupando boa parte das páginas.

A riqueza de detalhes dos textos amplia ainda mais a sensação da desgraça:

7 Impressiona o tamanho do número especial de Veja: 144 páginas. Delas, 62 estão destinadas à publicidade de grandes grupos e marcas. Sobressai a propaganda da Chevrolet, que apresenta uma série completa de seus veículos num encarte especial. 
Era tal a quantidade de pó e fumaça sobre Nova York que o fogo pôde ser visto até por astronautas embarcados na Estação Espacial Internacional, que sobrevoava o Estado do Maine na manhã da terçafeira, a mais de 300 quilômetros de altura. (ibidem, p.67)

Incêndios tomam conta das duas torres atingidas por aviões pilotados por terroristas. A cidade perde dois marcos de sua paisagem. (p.50)

Como os fanáticos destruíram os prédios mais altos de Nova York atirando dois Boeings de passageiros seqüestrados quase que simultaneamente, na mais ousada operação extremista de todos os tempos. (p.64)

Com o fim das ideologias e depois dos atentados, o planeta está agora obcecado pela segurança. Provavelmente, os Estados Unidos darão prioridade aos aliados que os ajudem na manutenção da ordem. É o tipo de discussão da qual o Brasil geralmente fica de fora. (p.53)

Após ilustrar amplamente o desastre, a revista passa para um segundo grande bloco destinado a mostrar os possíveis responsáveis por essas atrocidades. Inicialmente, identifica o inimigo número um dos Estados Unidos, além de Kadafi e Saddam Hussein: Osama bin Laden. Os pronunciamentos contra os americanos ganham projeção nessa parte: "Juramos todos os americanos de morte, sem distinção entre civis e militares"; "Os americanos vão nadar em seu próprio sangue, humilhamos a América"; "Os Estados Unidos são o Grande Satã". Vale a pena salientar que essas frases foram ditas numa outra época, portanto, numa conjuntura diferente da especificidade da revista, o que sugere a manipulação de Veja para reforçar suas ideias. A primeira teria sido dita em 1991 por Saddam Hussein, justamente alguém que não teve participação nesses episódios. A segunda remete a 1986 e foi pronunciada por Muamar Kadafi, que, já na época dos atentados, mantinha uma política não tão agressiva como a exercida naquele momento. Finalmente, a terceira, de autoria do aiatolá 
Khomeini, aconteceu em 1979, portanto refere-se a outro episódio, a outro acontecimento. ${ }^{8}$

Ao referir-se ao mundo árabe, a revista descreve com riqueza de detalhes os terroristas, suas características, seus países, seu mundo, suas ligações, suas origens. Realiza afirmações sem ter uma fonte, ou seja, faz essas assertivas por conta própria, resultando num texto emblemático que, pela sua relevância, vale a pena transcrever:

Ao longo da história, o mal já teve os traços de Átila, o Huno, do mongol Gêngis Khan, do austríaco Adolf Hitler, do soviético Josef Stalin, do cambojano Pol Pot e do ugandense Idi Amin Dada. Hoje o mal não comanda um exército, não mora em um palácio, não discursa a multidões, seu rosto é do saudita Osama bin Laden [...] o terrorista é tão assustador porque está sempre associado a um verbo condicional - ele seria, ele teria. Laden jamais reivindicou a autoria das brutalidades que levam a sua marca. Assassina, massacra e amedronta, mas se mantém na sombra, renunciando ao narcisismo que costuma caracterizar as ações terroristas. Laden é fruto de uma modalidade que surgiu em 1979, com a ascensão do aitolá Khomeini, no Irã: o terrorismo de Estado. Esse foi o caminho escolhido por tiranos muçulmanos para fustigar principalmente o que julgam ser o "Grande Satã" - os Estados Unidos. Trata-se de uma visão que mistura fundamentalismo religioso, oportunismo doméstico e obscurantismo. (p.68)

Os termos usados para identificar bin Laden e os países árabes são bastante eloquentes, isso sem destacar a manipulação da história realizada com personagens e episódios de interpretações pouco claras

8 O pronunciamento de Osama bin Laden foi realizado na época em que aconteceram os atentados das embaixadas americanas no Quênia e na Tanzânia, no mandato de Bill Clinton. A frase de Saddam Hussein data da Guerra do Golfo, na qual foi derrotado por George Bush pai. Já a de Kadafi ocorreu no bombardeio americano na Líbia, depois que ele ordenou os ataques a navios americanos, na época de Ronald Reagan, e, finalmente, o pronunciamento de Khomeini se deu na época de Jimmy Carter, após a invasão da embaixada americana pelas forças do aitolá. 
para os próprios historiadores. Ao inseri-los numa lista de outros governantes identificados com o mal, generaliza suas afirmações, criando um contexto unificado, sem que as motivações de cada fato ou personagem apresentado recebam um tratamento mais detalhado. $\mathrm{O}$ leitor menos avisado dificilmente poderá estabelecer diferenças entre os personagens apresentados, razão pela qual não terá que realizar nenhum esforço para identificar as peculiaridades deles. Assim, Osama bin Laden entra na lista dos detentores do mal.

Nas páginas seguintes, as observações feitas por Veja entram em contradição com as descritas anteriormente. De fato, o mundo árabe surge como um conjunto de nações que não patrocinam o terrorismo de bin Laden (p.70) e nem todos os seus habitantes são fundamentalistas. Mas, de acordo com Veja, ele causa admiração entre a população muçulmana e talvez por isso seja "um câncer que precisa ser extirpado". Sutilmente - uma ironia do destino, um ato de descuido - apresenta um fato de suma relevância, mas que passa sem muito detalhamento. Ao se indagar sobre as origens de bin Laden, menciona a relação existente, em 1979, entre o mesmo bin Laden e a CIA. Por causa da guerra fria, os Estados Unidos teriam treinado e dado dinheiro aos guerrilheiros do talibã, grupo liderado por bin Laden, para combater a União Soviética. Dessa aliança, resultou a consolidação e fortalecimento desse líder, que, empolgado com a vitória, decidiu libertar o resto das terras sagradas da presença dos estrangeiros. Esse fato teria marcado o início do afastamento dos Estados Unidos e bin Laden até tornarem-se inimigos mortais.

Identificado o terrorista, num terceiro momento Veja apresenta o mundo árabe. Embora formem um contingente populacional expressivo, apenas um pequeno grupo estaria disposto a morrer por Alá. Servindo-se das declarações da professora de História da USP Maria Aparecida de Aquino, Veja enfatiza as diferenças existentes dentro das etnias que compõem o denominado mundo árabe. No entanto, em diversos momentos a revista repudia o fundamentalismo islâmico apresentado como um componente atual e vivo nesse universo pouco conhecido pelo Ocidente. Assim, uma voz destoante da linha seguida perde força no contexto geral da revista. Aliás, convém destacar que, 
quando fala do futuro do mundo árabe, as distinções entre fundamentalistas e não fundamentalistas desaparecem. O mundo árabe é descrito como tirânico, autoritário e carente de democracia e desenvolvimento.

Ao juntar todas essas observações, percebemos que a revista Veja entendeu os atentados de 11 de setembro como resultado de ações isoladas praticadas por grupos terroristas merecedores da condenação e da punição por parte do denominado mundo civilizado. O editorial da revista ilustra de maneira bastante clara seu posicionamento, o que demarca sua linha na interpretação do fato. O que está em jogo não é simplesmente uma punição dos responsáveis, mas uma cosmovisão e concepções de valores subjacentes a esse fato. No editorial de Veja, essa questão fica evidente, como podemos observar a seguir:

O atentado foi cometido contra um sistema social e econômico que, mesmo longe da perfeição, é o mais livre e justo que a humanidade conseguiu fazer funcionar ininterruptamente, até hoje. Não foi um ataque de Davi contra Golias. Nem um grito dos excluídos do Terceiro Mundo que, de modo trágico mas efetivo, se fez ouvir no império. Foi uma agressão perpetrada contra os mais caros e frágeis valores ocidentais: a economia de mercado e a democracia. O que os radicais não toleram é a modernidade. É a existência de uma sociedade em que os justos podem viver sem ser incomodados e os pobres têm possibilidades reais de atingir a prosperidade com o fruto do seu trabalho. Esse é o verdadeiro anátema dos terroristas que atacaram os Estados Unidos. Eles são enviados da morte, da elite teocrática, medieval, tirânica que exerce seu poder absoluto nos seus feudos. Para eles a democracia é satânica. Por isso tem de ser combatida e destruída. (p.9)

Contrariamente ao posicionamento claramente tomado pela revista Veja, o Diplô publicou um dossiê especial no mês de outubro de 2001, ${ }^{9}$

9 Dossiê: "A era da guerra assimétrica". Disponível em: <www.uol.diplo.com. br>. No total são 14 artigos preocupados com as mais diversas questões relacionadas com os episódios de 11 de setembro de 2001. Acesso em: 15 nov. 2001. 
com 14 artigos elaborados por professores universitários, jornalistas e especialistas em relações internacionais. Já no editorial, escrito pelo seu diretor Ignacio Ramonet (2001b), deparamos com uma narrativa surpreendente:

Era o dia 11 de setembro. Desviados de sua rota habitual por pilotos decididos a qualquer coisa, os aviões caem sobre o coração da cidade, determinados a abater os símbolos de um sistema político odiado. Em um instante: as explosões, as fachadas voando em pedaços, os desabamentos num tumulto infernal, sobreviventes, apavorados, fugindo, cobertos de destroços. E a mídia, transmitindo a tragédia ao vivo...

Como o número especialmente aborda o 11 de setembro de 2001, o leitor, provavelmente, pensou que se encontrava diante de mais uma descrição do fim das torres gêmeas. Se não desistiu da leitura, nas cinco linhas seguintes, descobriu que o texto de Ramonet referia-se ao bombardeio da sede do governo de Allende, em Santiago do Chile, em 11 de setembro de 1973. A questão não é um mero jogo de retórica ou uma maneira de surpreender o leitor com a semelhança, até na data, desses acontecimentos.

Um pouco além da legítima compaixão para com as vítimas dos detestáveis atentados de Nova York, há de se convir que os Estados Unidos não são um país inocente. Não foram eles que participaram de ações políticas violentas, ilegais e muitas vezes clandestinas, na América Latina, na África, no Oriente Médio, na Ásia...? Ações que resultaram num trágico cortejo de mortos, "desaparecidos", torturados, encarcerados, exilados. (ibidem)

A fala inicial de Ramonet expressa a preocupação com as vítimas dos detestáveis atentados nos Estados Unidos. Aliás, a denominação empregada se assemelha com a de Veja. Porém, tal qualificação do acontecido não isenta os Estados Unidos de sua responsabilidade por exercer políticas internacionais claramente imperialistas geradoras 
de mortes e destruição de grupos, governos e países. Nesse ponto, a argumentação do diretor, na época, do Le Monde Diplomatique diverge da revista. No editorial não defende um país e culpa outro. Procura criar uma linha de raciocínio em que os fatos adquiram uma lógica, uma explicação da catástrofe ocorrida. Por esse motivo, prossegue na sua argumentação afirmando que

[... ] a partir de 1991, os Estados Unidos instalaram-se em uma posição de hiper-potência única, marginalizando, na prática, as Nações Unidas. Haviam prometido fundar uma "nova ordem internacional" mais justa. Foi em seu nome que travaram a guerra do Golfo, contra o Iraque. Por outro lado, no entanto, eles continuaram sendo escandalosamente parciais a favor de Israel, em detrimento dos direitos dos palestinos. Além do que, apesar dos protestos internacionais, mantiveram um bloqueio implacável contra o Iraque - que poupa o regime e mata milhares de inocentes. Tudo isso humilhou a opinião pública do mundo árabe-muçulmano, facilitando a criação de um viveiro de onde brota um islamismo anti-americano.

Identificados os possíveis motivos desencadeadores do fato em questão, o jornal abre suas páginas para apresentar outras versões nitidamente diferenciadas de Veja, como veremos a seguir. Não se trata de realizar reducionismos ou de simplificar quem representa o bem ou o mal nessa história, mas, sim, de atentar para as causas e contextualização onde se encaixam os "lamentáveis atentados". Assim, deveremos observar os procedimentos seguidos pelo Diplô do mesmo modo que foi feito com as notícias de Veja.

O tom dos artigos do Diplô parece estar marcado pela surpresa, foge do que se poderia esperar de um texto mais convencional. As manchetes comprovam essa tendência de procurar um sentido diferenciado, tal como pode ser observado a seguir: "O adversário"; "O Paquistão, um ator-chave"; "Demitidas e iludidas"; "Um inimigo difuso"; "Em nome do choque de civilizações"; "Somos todos norte-americanos"; "Do triunfalismo ao desastre"; "Televisão da compaixão"; "Dinheiro ou bombas?"; "Muçulmanos, cidadãos 
do mundo"; "Solidariedade"; "Imagens falsamente verdadeiras"; "Somos a América, saia da frente!".

Em razão desse posicionamento, o alvo inicial do ataque são os meios de comunicação ocidentais e a forma como deram cobertura e assumiram claramente o papel de defesa dos Estados Unidos. Vale a pena lembrar que Veja nem sequer toca no assunto. A televisão torna-se o objeto de ataque do Diplô pela maneira como se comportou nesse caso concreto. De acordo com Eric Klinenberg (2001), professor da New York University, autor do artigo Televisão de compaixão, o relato televisivo primou pela desinformação e pelo apelo emocional das pessoas surpreendidas pela força da imagem. Prova disso evidencia-se no desconhecimento total da maioria das pessoas nos Estados Unidos sobre por que esse fato aconteceu. Parece que houve uma corrida para ver quem apresentava a imagem mais chocante, mas pouco se aprofundou o papel de informar, próprio da mídia, no caso, a mídia televisiva.

Mesmo assim, não se pode afirmar que a mídia não tenha ocasionado algum tipo de efeito. Segundo Klinenberg (2001):

Todos os telespectadores se sentem sitiados e angustiados. Os boatos se multiplicam, divulgados em estado bruto, sem precauções. Não há tempo para verificar. Diz-se que um carro-bomba acaba de explodir diante do Departamento de Estado, que gases letais podem contaminar o ar de Manhattan; a Fox News antecipa um número de 20 mil mortos; edifícios oficiais e escolas são fechados, torres são evacuadas em Nova York, Chicago e Los Angeles; milhões de empregados voltam para casa correndo; o presidente Bush voa para local desconhecido.

O resultado dessas atitudes preparou as pessoas para aceitar o discurso de Bush quando declarou que o país estava em guerra e que deveria responder à altura. Consensualmente, a maioria da população aceitou essa fala e, de alguma forma, se sentiu aliviada sabendo que os autores dos atentados seriam punidos. Como passar do medo para 
a guerra? Klinenberg (2001) responde e justifica a transição realizada nas pessoas da seguinte maneira:

Tentando superar o horror, durante uma semana inteira os norte-americanos procurariam retomar o gosto pelas atividades do dia-a-dia. Dormem mal, trabalham pouco, têm medo. Mas, na televisão, o tom dominante não é de medo nem de dúvida. Os apresentadores e as autoridades políticas demonstram muita segurança, respondem com segurança a questões militares e diplomáticas. A tela, dividida em duas, transmite essa visão esquizofrênica que justapõe cenas de destruição e declarações de confiança. Os telespectadores, céticos quando o presidente Bush lhes anuncia que "os terroristas fracassaram”, aliam-se, no entanto, ao seu chamamento às armas.

As críticas, no entanto, não se restringem aos meios de comunicação e mais diretamente à televisão. A política externa americana aparece como a grande vilã para entender o 11 de setembro. Até o início de 1990, ela funcionou norteada pelo combate ao comunismo. Livres da ameaça comunista, os Estados Unidos passaram a agir como donos e senhores do mundo. Nesse contexto, os inimigos apareceriam entre seus anteriores aliados, como era o caso dos grupos que combateram a União Soviética no Afeganistão. Talvez por essa razão, os artigos do Le Monde Diplomatique possam ser separados por eixos temáticos: estratégia e política externa dos Estados Unidos; a manipulação e o mundo árabe.

As mudanças de estratégia dos Estados Unidos estão relacionadas à política externa aplicada por Zbigniew Brzezinski e no seu combate ao comunismo. De acordo com o Diplô, os americanos tinham noção bem clara do radicalismo dos grupos que apoiavam, o que lhes permitiria pressupor, pensando no futuro, conflitos e problemas de relacionamento devido ao antagonismo político, social e cultural entre eles e os talibãs. Mesmo assim, os grupos islâmicos receberam ajuda suficiente a ponto de assumir o poder político do Afeganistão. Foram de tal forma treinados que, após a expulsão dos invasores comunistas, permaneceram em condições de realizar atentados como os 
de 11 de setembro. A única saída que restava aos Estados Unidos para derrotar totalmente os talibãs, estrategicamente falando, consistia na concretização de novas alianças com os poucos confiáveis militares do Paquistão (Harrison, 2001).

Dessa forma, a informação passada para o leitor não se reduz à exposição dos fatos do momento. Amplia e aponta as consequências decorrentes das medidas tomadas pelos Estados Unidos, em momentos anteriores, divergindo bastante das afirmações da revista Veja. Quanto à questão estratégica, o Diplô mostra a incoerência do sistema de política externa mundial. Os Estados Unidos, sentindo-se agredidos, não hesitaram em pedir ajuda à Organização do Tratado do Atlântico Norte (Otan) para combater os terroristas. Mas, numa situação bem semelhante, no episódio das Malvinas, quando a Argentina pediu ajuda da Organização dos Estados Americanos (OEA) para defender seus interesses, os próprios americanos ignoraram essa solicitação. Dois pesos e duas medidas para a mesma situação. A diferença, num mundo globalizado, residiria em quem faz a petição e quem são seus aliados.

Para justificar as medidas contra os fundamentalistas árabes, torna-se necessário utilizar até o extremo a persuasão. Essa teria sido a missão dos militares ao usar os meios de comunicação. Nessa tentativa de manipulação da informação, as críticas do Diplô não perdoam os militares dos Estados Unidos. Steven C. Clemons (2001), vice- presidente da New America Foundation, sustenta que as autoridades americanas mentiram quando justificaram seu programa militar baseado na existência de um inimigo capaz de destruir seu país. $\mathrm{O}$ programa Guerra nas Estrelas foi vendido, via meios de comunicação, para a população americana. Clemons prossegue mostrando como ele não era nem urgente nem necessário. A imprensa permaneceu submissa diante das evidências e do anacronismo desse projeto. Os gastos do contribuinte acabaram tornando-se inúteis diante do ataque às torres gêmeas. Observa-se que Veja apela para o fenômeno contrário. Os inimigos existem e devem ser punidos, justificando a necessidade da guerra para levar a cabo tal ação. 
O poder da informação exercido pelo Estado americano enganou a população incapaz de contestar o modelo imposto por causa da ausência de críticas e opiniões contrárias expressas pela imprensa. $\mathrm{O}$ mesmo estaria acontecendo com as notícias divulgadas em relação ao mundo árabe. $\mathrm{O}$ fato de ter exibido imagens mentirosas, nas quais a população árabe pulava e cantava diante do ataque terrorista, implicava a generalização, homogeneização e simplificação de um mundo diverso e diferente. Essas imagens se encontram também nas páginas de Veja sem que exista nenhuma informação sobre as fontes usadas ou de onde saíram tais fotos. Mais uma diferença entre os dois meios de comunicação. Como escreve Philip S. Golub (2001): "Sempre nos contentamos em denunciar os terroristas como bad boys, sem nos interessarmos em compreender os seus motivos". Com certeza, existem outros motivos que devem ser levados em consideração.

Em razão disso, o Le Monde Diplomatique realiza um esforço significativo no sentido de apresentar vozes, dentro dos Estados Unidos, contrárias às medidas que começavam a ser tomadas sem que houvesse uma reflexão sobre seus possíveis desdobramentos. Esse tema está fora de cogitação em Veja. Nela, a unanimidade e o apelo para que os outros países ajudassem os Estados Unidos na retaliação contra o terrorismo prevalecem. O Diplô abre espaço para a contradição, como comprova o texto a seguir:

Em plena histeria de guerra, é difícil chamar os Estados Unidos à razão. E, no entanto, algumas vozes discordantes se fazem ouvir. Robert Reich, ex-ministro do Trabalho, afirma: "Talvez os Estados Unidos estejam em guerra, mas se o castigo e os nossos discursos forem entendidos como ações dirigidas contra a totalidade do mundo árabe, então os terroristas terão conseguido o que queriam". O diretor do jornal International Herald Tribune, David Ignatius, escreveu: "É muito fácil começar uma guerra, mas é difícil terminá-la. Essa é uma regra que os terroristas foram inteligentes em não esquecer e que deveria orientar os dirigentes norte-americanos". William Pfaff, editorialista do Los Angeles Times, salienta que, há mais de trinta anos, "os Estados Unidos vêm se recusando a fazer um esfor- 
ço realmente imparcial para encontrar uma solução para o conflito [entre israelenses e palestinos]. Envolveram-se de mil maneiras no Oriente Médio, mas nunca agiram de forma justa”. (Golub, 2001) $)^{10}$

O mundo árabe, tal como apresentado pelo professor da Universidade de Princeton, Hicham Ben Adballah El Alaoui (2001), fundador do Instituto de Estudos Contemporâneos sobre o Norte da África, o Oriente Médio e a Ásia, representa uma complexidade maior do que aparenta ser. Na Veja, vimos que essa afirmação só aparece quando uma pessoa da academia, a professora de História Maria Aparecida de Aquino, salienta o tema da diversidade do mundo árabe. $\mathrm{O}$ autor reconhece as disparidades e injustiças que se encontram estabelecidas dentro das sociedades árabes, dominadas por elites autoritárias e conservadoras. El Alaoui denuncia a exclusão social e política existente na maioria dos países árabes, mas sustenta veementemente que a maioria da população árabe muito pouco tem a ver com o fundamentalismo e os talibãs. Por essa razão, os meios de comunicação não podem falar em terroristas, referindo-se aos árabes como um conjunto unificado e coeso. A imprensa mundial deveria prestar mais atenção nas suas informações.

Dando prosseguimento às suas considerações, El Alaoui (2001) aponta algumas razões pelas quais pode ter acontecido esse ato terrorista:

Os odiosos ataques alimentam-se, no mundo árabe-muçulmano, da raiva e da humilhação dos povos abandonados por uma ordem mundial que os marginaliza. A existência de uma rede capaz de tamanha violência em nome do Islã obriga-nos - a nós, muçulmanos - a esclarecer a nossa posição com relação ao "fundamentalismo islâmico". Em parte, o Ocidente é responsável, mas não podemos nos esquivar de nossa própria responsabilidade. Refiro-me à escalada de um islamismo política e socialmente totalitário, organizado com base em grupos armados, que fazem uma interpretação unilateral dos textos sagrados.

$10 \mathrm{O}$ autor desse texto é professor da Universidade Paris VIII e jornalista. 
Motivos internos e externos confluem para um final nada alentador. Alerta para o perigo das retaliações tal como se anunciavam nos Estados Unidos. Persistindo a pobreza e a marginalização, o terreno para o crescimento dos grupos terroristas estava preparado. Alerta, ainda, para desdobramentos e incremento desses grupos radicais, correndo os riscos de assumir o controle de países detentores de armas atômicas, como é o caso do Paquistão. Na eventualidade de uma materialização desse alerta, o perigo para o desdobramento de um conflito atômico seria real. Diante do quadro, a sugestão de El Alaoui se volta para a construção do diálogo e do respeito, assim como propõe mudanças estruturais dentro do mundo árabe para acabar com as desigualdades internas e a estagnação.

Nessa linha de raciocínio, Tariq Ali (2001), escritor paquistanês, na mesma edição do Diplô, sugere que a imprensa aborde a questão dos terroristas do ponto de vista de um confronto entre duas civilizações, entre dois mundos completamente antagônicos quando se fala em cultura, política, sociedade ou religião. No contexto da globalização, defende Tariq Ali, torna-se vital a compreensão das suas peculiaridades, evitando fazer julgamentos a priori. São dois mundos em confronto. A revista Veja não fala nesse tipo de divisão, até porque realiza um reducionismo bastante claro nas suas abordagens: estaríamos no conflito entre o bem e o mal.

Ao compararmos a abordagem dos dois meios de comunicação, percebemos como a revista Veja não aprofundou aspectos críticos envolvidos nos atentados de 11 de setembro de 2001. A leitura sugere que os ataques representam a barbárie e que seus promotores devem ser severamente punidos, posição essa defendida pelos Estados Unidos. Assim, coincidem as interpretações da revista com as do governo americano. A abundância e o exagero de elementos gráficos e de fotos reafirmam os conteúdos da Veja. O Diplô manifesta maior preocupação com o conteúdo das suas informações, abre seu espaço para especialistas em assuntos árabes e provoca a reflexão no leitor quando levanta pontos de interrogação que ultrapassam o momento presente. Por meio de textos rápidos, o leitor entra na discussão da diversidade cultural, do jogo de interesses, e instiga-se a procura de 
outras informações sobre o tema. Estamos diante de dois enfoques claramente diferenciados.

Essas constatações permitem aferir que existem diferenças profundas dentro do jornalismo que correspondem a posicionamentos diferenciados diante dos quais dois universos se configuram. De fato, a opção do Diplô atrai mais e abre muitas possibilidades se comparada à oferecida pela Veja. A fórmula seguida pelo Diplô causa mais avanços do que a proposta pela Veja, em parte por seguir alguns dos ensinamentos básicos do jornalismo: respeito pelo contraditório, apresentar fontes diversas, contextualizar da maneira mais detalhada possível o fato estudado, ouvir especialistas e conhecedores do assunto, entre outros.

As melhores possibilidades de aproximação com a história se encontram no Diplô, embora Veja não possa ser descartada, pois sua informação não deixa de representar também uma versão. $\mathrm{O}$ atual ou a atualidade, no Diplô, não prima pelo sensacionalismo, ao contrário, realiza um exercício de reflexão e de levantamento do passado para reafirmar suas ideias. Não condena Osama bin Laden nem o presidente dos Estados Unidos, ou seja, não personaliza a questão. Em momento algum, encontramos no Diplô incentivo às retaliações ou às justificativas para dar o troco com a mesma moeda. Inclusive, alerta para o perigo dessas atitudes por terem desdobramentos imprevisíveis. Não simplifica as análises (bem versus mal) nem aceita que o mundo árabe seja ou represente uma esperança para criar algo diferente política, econômica ou socialmente. Critica o radicalismo de ambas as partes e aponta sinais de fraqueza no mundo árabe, espaço no qual se alimentam os fundamentalismos.

Por esses motivos, o Le Monde Diplomatique se destaca em comparação à revista Veja. Abre as possibilidades de aproximação com a história pela semelhança de procedimentos como os apontados anteriormente (análise de conjuntura, inserção numa perspectiva ampla, previsão de consequências, apontamento de interesses envolvidos, entre outros). Contudo, devemos deixar claro que a aproximação e a convergência apontadas não significam que ambos os meios apresentam versões acabadas ou mais elaboradas, como a apresentação 
de documentos e outros recursos que podem interferir diretamente na abordagem desse episódio.

Justamente nesse momento entra a história, completando, pelo uso de seus métodos e procedimentos, as interpretações e os motivos ocasionadores desse desastre. O surgimento de documentos novos e novas informações pode mostrar a inconsistência das interpretações dos meios de comunicação analisados, mesmo sendo tão diferentes. Mas isso fica em aberto para o futuro e na pendência de um trabalho mais acurado e completo, dependendo de documentação ou de depoimentos. 


\section{ConCLUSÃo}

Encontros e desencontros marcam a aproximação da história com a comunicação e, mais especificamente, com o jornalismo. Sua finalidade principal consiste em informar e despertar a criticidade por apresentar notícias e fatos que, sem a sua divulgação, nem sequer se tornariam públicos. Os meios de comunicação e a história cumprem, portanto, uma função socializadora. Entretanto, algumas diferenças parecem abrir espaços para criar situações que, dificilmente, conseguirão ser superadas. Na execução de suas atividades diárias, ambos podem utilizar as mesmas fontes, mas ficou claro que, na hora de valorizá-las, existem, sim, diferenças entre jornalistas e historiadores. Inclusive, nem sempre coincidem na hora de usar as mesmas fontes.

O historiador apoia-se, fundamentalmente, em documentos que adquirem relevância na medida em que podem ser contrastados com fontes de outra natureza para ter mais segurança na hora de realizar as interpretações. O comunicador deve seguir esse procedimento, porém a premência do tempo nem sempre lhe permite agir dessa forma. Suas fontes acabam sendo as orais, salvo quando pode realizar trabalhos investigativos sem depender do fator tempo. Claro que existe o confronto de fontes no jornalismo, mas essas fontes também são primordialmente orais - ainda que, mesmo no jornalismo diário, o jornalista possa recorrer também a fontes bibliográficas e documen- 
tos, como boletins de ocorrência policial -, o que não deixa de ter sua relevância na hora de elaborar seu texto. É verdade que o historiador também as vê como fontes interessantes, mas, como dispõe de todo o tempo de que precisa para verificá-las, contrastá-las e interpretá-las, as fontes orais não se tornam imprescindíveis para o exercício de sua profissão. Contudo, é possível que essa diferença seja de ordem acidental, pois alguns dados que eventualmente não se encontram em documentos provêm de relatos de pessoas, de testemunhas, de atores que confiam em jornalistas e revelam situações que, sem isso, se perderiam. Abre-se, apesar das ressalvas e da diferença nos seus procedimentos, uma possibilidade de diálogo entre a história e o jornalismo.

História e jornalismo confluem na medida em que tentam apresentar para seus públicos uma narrativa coerente, com sentido, aceitável e acolhida pelos seus receptores. Para isso, utilizam-se, na forma de escrever, de algumas técnicas parecidas. Ao se pronunciar sobre ações e atos humanos, a narrativa criada é apresentada de maneira viva, envolvendo os atos e as pessoas num mesmo patamar, despertando a curiosidade e o interesse dos leitores. Existe, nesse âmbito, uma sintonia na apresentação das histórias suficientemente forte para facilitar "empréstimos" entre jornalistas e historiadores.

Decorrente dessa melhora na qualidade da narrativa, há também uma melhora na qualidade da informação. Essa questão não pode ser entendida sem as observações anteriores. De fato, na medida em que o jornalista consiga associar os fatos conhecidos e as pessoas em uma trama com sentido, servirá melhor ao público e terá uma resposta mais ampla, além de aumentar a credibilidade no seu trabalho. Caso isso não ocorra e esse profissional se limite a citar séries de fatos isolados e a apresentar pessoas que atuam sem integrá-las em um todo com sentido, estará oferecendo uma informação de pouca qualidade e, provavelmente, não receberá a resposta desejada. Para narrar melhor, o jornalista tem que primar pela busca constante dos fatos. Esse seria o diferencial na hora de elaborar sua história. O mesmo se verifica na história. $\mathrm{O}$ historiador não é um mero executor de uma lista de dados. Tem de criar uma narrativa com vida, com informações 
e, principalmente, com coerência. Isso só se consegue na medida em que realiza o mesmo processo adotado pelo jornalismo, ou seja, procura fontes, explora documentos, analisa rigorosa e detalhadamente as informações e produz uma escrita capaz de cativar o leitor.

Uma diferença importante na execução de suas atividades se encontra no modo de atuação de cada área. O jornalista narra de dentro dos acontecimentos. Sua narrativa remete a processos ainda em curso, abertos, sem ter um desfecho conhecido. Contrariamente, salvo na denominada história a debate, o historiador conhece o desfecho do assunto estudado. Por esse motivo, o cuidado dos jornalistas com seus personagens deve ser redobrado, pois ainda estão presentes enquanto escreve. Pelo fato de tratar do passado, o historiador exerce sua função de forma mais livre, podendo emitir juízos e valores mais radicais sobre seus personagens. Tal radicalismo serve de base para desmistificar e elaborar um senso de realidade diferente daquele do jornalismo.

As relações que jornalismo e história estabelecem com seu objeto de análise implicam espaços de aproximação e confrontação entre essas práticas. Se a realidade social captada pela história nem sempre está de acordo com os critérios de noticiabilidade jornalística, podemos dizer que, em certos momentos, o jornalista "escreve" a história - produzindo um material que será mais tarde utilizado pelos historiadores como corpus documental. Por essa razão, a frase tão aceita de que o jornalismo de hoje será a história de amanhã precisa ser tratada mais cautelosamente. O jornalismo demanda mais cuidados do que a escrita da história.

As considerações esboçadas nas linhas anteriores, embora mostrem duas maneiras claramente delimitadas para explicar os acontecimentos, revelam, também, que essas concepções precisam dialogar mais. Mostramos que, apesar de ser uma área nova, a comunicação refletiu nas suas abordagens muitas das teorias e enfoques seguidos pela história. Aproximar não significa estabelecer limites. O desejo de participar do social, por parte dos historiadores, não deve ignorar a maneira como o jornalismo constrói as informações, e, muito menos, devem-se ignorar suas limitações. Ainda, cabe apontar que 
nem sempre o jornalismo direciona suas atividades para o campo da informação. Muitas das opiniões jornalísticas referem-se ao entretenimento e ao lazer, temas esses presentes já nos primórdios do jornalismo. Separar o fato da ficção é vital para não estabelecer parâmetros equivalentes para essas duas categorias.

Decorrente da questão anterior, emerge uma outra não menos importante e que separa a história do jornalismo. O jornalista nem sempre pode mostrar suas fontes. A rigor, pelo menos no caso da história, essa seria uma das garantias para realizar as afirmações. As fontes têm que aparecer, pois, sem elas, duvida-se de algumas afirmações ou procedimentos realizados no desenvolvimento de suas atividades. Já o jornalista não possui tanta liberdade para operar desse modo, uma vez que alguns dados chegam ao público por se oferecer anonimato aos seus informantes. Dessa maneira, aceitar essa informação como verdadeira implica acreditar sem poder ver a fonte. Não que isso seja fundamental, mas, dentro de uma construção de caráter científico, na qual se estabelece o diálogo entre as duas áreas, resulta, no mínimo, estranho.

Apesar dessas constatações, pela nossa experiência nesses últimos anos, temos claro que é possível realizar aproximações frutíferas entre o jornalismo e a história. $\mathrm{O}$ intercâmbio de saberes proporciona a assimilação das práticas de cada área de conhecimento, originando ganhos para as duas. A história se dinamiza na sua escrita e na ampliação de suas fontes. O jornalismo adquire profundidade por exercer o rigor nas suas interpretações. Um caminho sugerido, nessa tentativa de trocar ideias para aparar as arestas, aponta para entender o jornalismo dentro de uma dinâmica maior, a da comunicação social. No texto, mostramos as dificuldades para se estabelecer um saber específico dessa grande área de conhecimento. Assim entendida, a comunicação social se preocupa com o estabelecimento de formas eficientes de avaliar a relação entre o emissor, o meio e o receptor. Justamente na construção do processo, a comunicação tem valorizado muito a sociologia, resultando na ausência de uma contextualização mais organizada, capaz de situar no tempo e no espaço seu objeto de estudo. Essa nos parece ser outra possibilidade 
de bom relacionamento. As notícias provenientes dessa mudança, sem dúvida, terão mais sentido e significado do que sendo alocadas de qualquer maneira.

O exemplo estudado evidencia muito bem essa questão. A revista Veja serve-se de conceitos pouco explicados; usa a história sem ter uma visão crítica dela, esta apenas representa mais uma ferramenta para legitimar sua postura. Em suma, a preocupação mostrada se reduz a um simplismo preocupante ao se pensar no número de leitores que têm acesso a essa informação. Já o Diplô fundamenta suas afirmações sem emitir juízos, apenas cria diversidade e abre as possibilidades por dar voz às partes envolvidas. Estaria mais perto esse jornal da visão de informação como processo do que a Veja.

As diferenças existem, sim. Sem dúvida, a mais angustiante é a de dar um sentido ao cotidiano que leve a uma transformação social. A impressão que fica é que, no meio do caminho, outros componentes agem alterando as perspectivas criadas em torno dos fatos. Talvez essa seja outra coincidência entre jornalismo e história. Seu poder de persuasão esbarra num tipo de poder não tão visível nem tão fácil de ser desmascarado. 



\section{REFERÊNCIAS BIBLIOGRÁFICAS}

ADORNO, T.; HORKHEIMER, M. Dialética do esclarecimento. Rio de Janeiro: Jorge Zahar, 1985.

ALI, T. Em nome do choque das civilizações. Le Monde Diplomatique Brasil, ano 2, n.21, out. 2001. Disponível em: <www.diplo.com.br>. Acesso em: 20 jan. 2003.

AMARAL FILHO, M. J. T. do. Privatização no Estado contemporâneo. São Paulo: Ícone, 1996.

ANDERSON, P. Balanço do neoliberalismo. In: SADER, E.; GENTILI, P. (Org.) Pós-neoliberalismo: as políticas sociais e o Estado democrático. Rio de Janeiro: Paz e Terra, 1995.

BARROS, C. Manifesto. Disponível em: < http://www.h-debate.com />. Acesso em: 21 dez. 2007.

BATISTA JR., P. N. O círculo de giz da globalização. Novos Estudos (São Paulo), n.49, 1979.

BÉDARIDA, F. Tempo presente e presença na história. In: FERREIRA, M. de M.; AMADO, J. (Org.) Usos e abusos da história oral. Rio de Janeiro: FGV, 1996.

BOURDIEU, P. El ofício de sociólogo. México: Siglo Veinteuno, 1978. A economia das trocas simbólicas. São Paulo: Perspectiva, 1987. Razões práticas. São Paulo: Papirus, 1997a. Sobre a televisão. Rio de Janeiro: Zahar Editores, 1997b. O poder simbólico. Rio de Janeiro: Bertrand Brasil, 2003.

BRAUDEL, F. Escritos sobre a história. São Paulo: Perspectiva, 2007. 
BURKE, P.; BRIGGS, A. A escrita da história - Novas perspectivas. São Paulo: Editora UNESP, 1992.

BURKE, P.; BRIGGS, A. Uma história social da mídia - de Gutenberg à internet. Rio de Janeiro: Jorge Zahar, 2002.

CARDOSO, C. F.; MALERBA, J. (Org.) Representações: contribuições a um debate transdisciplinar. Campinas: Papirus, 2000.

CASTELLS, M. A sociedade em rede. Rio de Janeiro: Bertrand Brasil, 2002.

CERTEAU, M. de. A escrita da história. Rio de Janeiro: Forense Universitária, 1982.

CHAPARRO, M. C. Pragmática do jornalismo. São Paulo: Summus, 1994.

CHARTIER, R. A ordem dos livros: leitores, autores e bibliotecas na Europa entre os séculos XIV e XVIII. Brasília: Editora UnB, 1994.

CHAUVEAU, A.; TÉTARD, P. (Org.) Questões para a história do presente. Bauru: Edusc, 1999.

CLEMONS, S. C. Do triunfalismo ao desastre. Le Monde Diplomatique Brasil, ano 2, n.21, out. 2001. Disponível em: <www.diplo.com.br>. Acesso em: 20 jan. 2003.

CONSTANTINO, R. A liberdade individual e o capitalismo. Mídia sem Máscara (São Paulo), fev. 2004. Disponível em: <http:www.midia semmascara.com.br/artigo.php?sid=1418>. Acesso em: 19 ago. 2005.

COSTA, B. Veja, como ela é. Disponível em: <www.fazendomidia.com/ fmoutros/materia0011.htm>. Acesso em: 25 ago. 2005.

DANTAS, M. A lógica do capital-informação. Revista Comunicação e Política, n.VIII, 1996.

DIAZ, J. M.; ALFFOND, J. C. R. Introducción a la historia de la comunicación social. Madri: Ariel, 2001.

DIZARD JR., W. A nova mídia. Rio de Janeiro: Jorge Zahar, 1998.

DOSSE, F. História do estruturalismo. Campinas: Editora da Unicamp, 1994. 2v.

DREIFUSS, R. O jogo da direita. Petrópolis: Vozes, 1989.

DUMOULIN, O. História contemporânea. In: BURGUIÈRE, A. (Org.) Dicionário das ciências históricas. Rio de Janeiro: Imago, 1993.

DUPAS, G. A lógica econômica global e a revisão do Welfare State: a urgência de um novo pacto. In: BRESSER PERREIRA, L. C. et al. Sociedade e Estado em transformação. São Paulo: Editora UNESP; Brasília: Enap, 1999.

ECO, U. Un historiador inquieto. El País, 30 mar. 2008. 
EL ALAOUI, H. A. Muçulmanos, cidadãos do mundo. Le Monde Diplomatique Brasil, ano 2, n.21, out. 2001. Disponível em: <http://diplo. uol.com.br/2001-10,a80>. Acesso em: 20 jan. 2003.

ESCOSTEGUY, A. C. Cartografias dos estudos culturais: uma versão latino-americana. Belo Horizonte: Autêntica, 2001.

FEBVRE, L. (Org.) Combates por la historia. Barcelona: Ariel, 1986.

FERREIRA, E. A. C. Nova ordem mundial. São Paulo: Núcleo, 1997.

FIOL, A. Estudio de los medios. Propiedad y acceso a los medios de comunicación en el mundo. Jun. 2001. Disponível em: <http://www. comunica.org/chasqui/principio>. Acesso em: 23 ago. 2005.

FONTCUBERTA, M.; BORRAT, H. Periódicos: sistemas complejos, narradores em interacción. Buenos Aires: La Crujía, 2006.

FUENTES, R. La investigación de la comunicación en América Latina. Diálogos de la Comunicación. n.56, oct. 1999.

FUNCEP. Os limites da intervenção do Estado. Estatização ou privatização: Seminário Internacional. Brasília: Fundação Centro de Formação do Servidor Público, 1987.

FURET, F. Marx e a Revolução Francesa. Rio de Janeiro: Zahar, 1989. Revolução em debate. Bauru: Edusc, 2001.

GAMBOA, Á. S. Historia del presente: Estado de la cuestión y conceptualización. Revista Electrônica Historia Actual On-Line, año II, n.3, 2004. Disponível em: <http://www.hapress.com>. Acesso em: 20 jan. 2005. GAY, P. O estilo na história. Gibbon, Ranke, Macaulay, Burckhart. São Paulo: Companhia das Letras, 1990.

GOHN, M. da G. Teoria dos movimentos sociais. Paradigmas clássicos e contemporâneos. São Paulo: Loyola, 1997.

GOLUB, P. S. Vozes discordantes. Disponível em: < http://diplo.uol.com. br/2001-10,a63>. Acesso em: 15 out. 2001.

HALL, S. A identidade cultural na pós-modernidade. Rio de Janeiro: DP\&A, 2005.

HARRISON, S. S. O Paquistão, um ator-chave. Le Monde Diplomatique Brasil, ano 2, n.21, out. 2001. Disponível em: <www.diplo.com.br>. Acesso em: 20 jan. 2003.

HELD, D.; MCGREW, A. Prós e contras da globalização. Rio de Janeiro: Jorge Zahar, 2001.

HERSCOVITZ, H. A pesquisa em comunicação na América Latina: desafios nos anos 90. Comunicação E Sociedade (São Bernardo do Campo), ano XIII, n.23, jun. 1995. 
HOBSBAWM, E. A era dos extremos. O breve século XX: 1914-1991. São Paulo: Companhia das Letras, 1995. . Teorias da globalização. Rio de Janeiro: Civilização Brasileira, 1999. A era do império. Rio de Janeiro: Paz e Terra, 2007.

KLINENBERG, E. Televisão de compaixão. Disponível em: <http:// diplo.uol.com.br/2001-10,a77>. Acesso em: 15 out. 2001.

LACOUTURE, J. A história imediata. In: LE GOFF, J. (Org.) A história nova. São Paulo: Martins Fontes, 1995.

LAGO, C.; BENETTI, M. Metodologia de pesquisa em jornalismo. Petrópolis: Vozes, 2007.

LE GOFF, J. A visão dos outros; um medievalista diante do presente. In: CHAUVEAU, A.; TÉTARD, P. (Org.) Questões para a história do presente. Bauru: Edusc, 1999.

LE MONDE DIPLOMATIQUE BRASIL. Ano 2, n.21, out. 2001. Disponível em: <http://diplo.uol.com.br/2001-10,r21>. Acessado em: 15 fev. 2008.

LIMA, V. Mídia: teoria e política. São Paulo: Perseu Abramo, 2001.

A concentração da propriedade midiática. 2003. Disponível em: <www.fpa.org.br/noticias/venicio_radiobras.htm>. Acesso em: 23 ago. 2005.

MARCONDES FILHO, C. Jornalismo fin-de-siècle. São Paulo: Scritta, 1993.

MARTÍN-BARBERO, J. Dos meios às mediações. Rio de Janeiro: Editora da UFRJ, 2007.

MARTINO, L. C. (Org.) Teorias da comunicação: muitas ou poucas? São Paulo: Ateliê, 2007.

MARX, K. Revolução e contra-revolução. Lisboa: M. Rodrigues Xavier, 1971.

Burguesia e a contra-revolução. São Paulo: Ensaio, 1987.

MASTRINI, G.; BECERRA, M. 50 años de concentración de medios en América Latina: del patrimonio artesanal a la valorización en escala. 2003. Disponível em: <www.saladeprensa.org>. Acesso em: 24 jul. 2005.

MATEOS, A. Historia, memoria, tiempo presente. Disponível em: <http://hispanianova.rediris.es >. Acesso em: 13 abr. 2000.

MATTELART. A. História das teorias da comunicação. São Paulo: Loyola, 1995. 
A globalização da comunicação. Bauru: Edusc, 2002.

MCCHESNEY, R. Mídia global, neoliberalismo e império. In: MORAES, D. de. (Org.) Por uma outra comunicação: mídia, mundialização cultural e poder. Rio de Janeiro: Record, 2003.

MCLUHAN, M. A galáxia de Gutenberg: a formação do homem tipográfico. São Paulo: Edusp, 1972.

MELO, J. M. Jornalismo brasileiro. Rio Grande do Sul: Sulina, 2003.

MILMAN, L.; VIZENTINI, P. Neonazismo, negacionismo e extremismo político. Porto Alegre: Editora da Universidade, 2000.

MORAES, D. de. O capital da mídia na lógica da globalização. In: . (Org.) Por uma outra comunicação: mídia, mundialização cultural e poder. Rio de Janeiro: Record, 2003.

MOTTA, L. G. et al. Notícia e construção de sentidos: análise da narrativa jornalística, Revista Brasileira de Ciências da Comunicação (São Paulo), v.XXVI, n.1, 2005.

MOUILLAUD, M.; PORTO, S. (Org.) O jornal. Da forma ao sentido. Brasília: Editora UnB, 2002.

MUDROVCIC, M. I. Algunas consideraciones epistemológicas para una "Historia Del Presente". Disponível em: <http://hispanianova.rediris. es>. Aceso em: 13 abr. 2000.

NEGRI, A.; HARDT, M. Império. Rio de Janeiro: Record, 2001.

NORA. P. O retorno do fato. In: LE GOFF, J.; NORA, J. (Org.) História: novos problemas. Rio de Janeiro: Francisco Alves, 1995.

PERKINS, J. Confissões de um assassino econômico. São Paulo: Cultrix, 2005. RAMONET, I. Geopolítica do caos. Petrópolis: Vozes, 2001a.

. O adversário. Le Monde Diplomatique Brasil, ano 2, n.21, out. 2001b. Disponível em: <www.diplo.com.br>. Acesso em: 20 jan. 2003.

Propagandas silenciosas: massas, televisão, cinema. Petrópolis: Vozes, 2002a.

RAMONET, I. Informarse cuesta. Mensagem recebida de sector3@sector. net em 3 de setembro de 2002b.

Guerras do século XXI. Novos temores, novas ameaças. Petrópolis: Vozes, 2003.

A mídia concentrada. Disponível em: <http://www.umacoi saeoutra.com.br/marketing/ramonet.htm>. Acesso em: 20 jul. 2005.

RÉMOND, R. Algumas questões de alcance geral à guisa de introdução. In: FERREIRA, M. de M.; AMADO, J. (Org.) Usos e abusos da história oral. Rio de Janeiro: FGV, 1996. 
RICOEUR, P. Tempo e narrativa. Campinas: Papirus, 1994. t.I.

RIOUX, J-P. Os meios de comunicação como extensão do homem. São Paulo: Cultrix, 1996.

. Entre a história e o jornalismo. In: CHAUVEAU, A.; TÉ-

TARD, P. (Org.) Questões para a história do presente. Bauru: Edusc, 1999.

SADER, E. Perspectivas. Rio de Janeiro: Record, 2005.

SANTOS, M. O país distorcido: o Brasil, a globalização e a cidadania. Org. Wagner Costa Ribeiro. São Paulo: Publifolha, 2002.

SHIEGLER, B. O desejo asfixiado, ou como as indústrias culturais liquidam o indivíduo. Le Monde Diplomatique Brasil, ano 5, n.53, jun. 2004.

Disponível em: <www.diplo.com.br>. Acesso em: 25 jul. 2005.

SIMONSEN. M. H. Novos desafios da economia brasileira. In:VELLOSO,

J. J. J. R. (Org.) O real e o futuro da economia. Rio de Janeiro: José Olympio, 1995.

SOARES, P. Essas malditas tradições. Disponível em: <www.fazendomidia. com/novas/politica24805.htm>. Acesso em: 25 ago. 2005.

STIGLITZ, J. E. A globalização e seus malefícios. São Paulo: Futura, 2002. Os exuberantes anos 90. São Paulo: Companhias das Letras, 2003.

THOMPSON, E. P. A formação da classe operária inglesa. Rio de Janeiro: Paz e Terra, 1987. v.3.

THOMPSON, J. B. Ideologia e cultura moderna. Petrópolis: Vozes, 1995. A mídia e a modernidade. Petrópolis: Vozes, 1998.

VEJA. Edição especial, ano 34, n.1718, 19 set. 2001.

VEYNE, P. Como se escreve a história. Lisboa: Edições 70, 1983.

VILAR, P. Pensar históricamente. Reflexiones y recuerdos. Barcelona: Crítica, 1997.

VOVELLE, M. Ideologias e mentalidades. São Paulo: Brasiliense, 1987.

WILLIAMS, R. Historia de la comunicación. De la imprenta a nuestros días. Barcelona: Bosch, 1992.

WOLF, M. Teorias da comunicação. Lisboa: Presença, 1987. 
Anexos 



\section{ANEXO 1 \\ ReVISTA Veja}

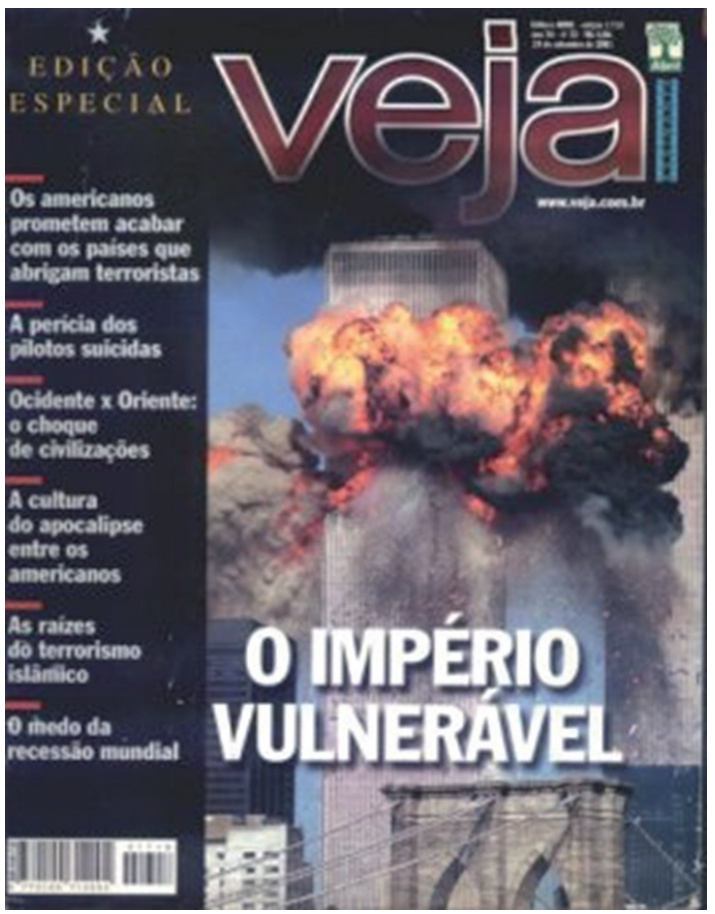

19 de setembro de 2001

"O império vulnerável" 



\section{ANEXo 2 \\ Le Monde Diplomatioue}

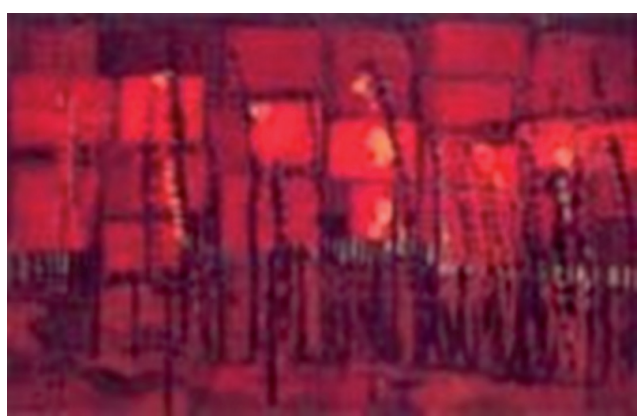

Outubro de 2001

O ADVERSÁRIO

"Os atentados de 11 de setembro devolveram à direita norteamericana - os assessores mais próximos de Bush - um importante dado estratégico de que os havia privado o colapso da União Soviética, há dez anos: um adversário. Finalmente!" (Ignacio Ramonet)

\section{O PaquistÃo, UM ATOR-CHAVE}

"A escalada de um fundamentalismo islâmico radical no sul da Ásia é uma herança do apoio incondicional que os EUA deram, 
durante a guerra do Afeganistão, a Zia Ul Haq e aos seus serviços de informação, o 'Interservices Intelligence Directorate' (ISI).” (Selig S. Harrison)

\section{DEMITIDAS E ILUDIDAS}

"Por uma curiosa, mas clássica, reversão da relação entre causa e efeito, a responsabilidade pela perda do emprego era devolvida às mulheres demitidas. Um emprego 'se merece', ele depende da 'empregabilidade'. Conseguiriam elas merecê-lo?” (Noëlle Burgi)

\section{UM INIMIGO DIFUSO}

"Operações maciças e rápidas de bombardeios de grande altitude levaram os norte-americanos a pensar que poderiam ganhar guerras sem um único morto. A transformação de quatro aviões civis em bombas voadoras acaba de pôr fim a essa idéia." (Marwan Bishara)

\section{EM NOME DO CHOQUE DE CIVILIZAÇÕES}

"Em 1993, um assessor do governo norte-americano advertia que o Ocidente (ou seja, os Estados Unidos) deveria preparar-se militarmente para enfrentar civilizações como o Islã e o confucionismo que, unidas, ameaçariam o coração do mundo ocidental."(Tariq Ali)

\section{"SOMOS TODOS NORTE-AMERICANOS"}

"Num programa gravado pela France Inter em Nova York, a jornalista de plantão relembrava a cada minuto o horário da Costa Leste. Visivelmente, ela se tornara uma das nossas. Todos norte-americanos, nós vivemos em Nova York e falamos todos inglês." (Serge Halimi)

\section{DO TRIUNFALISMO AO DESASTRE}

“Os Estados Unidos não compreenderam a verdadeira natureza das novas relações internacionais, nem a distância radical que separa sua visão - de satisfação consigo próprios - e o olhar que lhe lançam as outras nações e povos do mundo." (Steven C. Clemons) 


\section{TELEVISÃO DA COMPAIXÃO}

"Em tempos de crise, a televisão não é apenas um meio de comunicação que traz informação. É também um palco onde se representam os principais atos da política. Na hora da compaixão e da vingança, discordâncias e diferenças não têm espaço no vídeo." (Eric Klinenberg)

\section{DINHEIRO OU BOMBAS?}

"O efeito dos atentados foi a expressão de um pensamento obtuso: "agressão contra o estilo de vida, devida ao ódio à nossa prosperidade e à nossa paz'." (Saskia Sassen)

\section{Muçulmanos, CIDADÃos DO MUNDO}

"Em parte, o Ocidente é responsável, mas não podemos negar nossa responsabilidade na escalada de um islamismo política e socialmente totalitário, organizado com base em grupos armados que fazem uma interpretação unilateral dos textos sagrados." (Hicham Ben Abdallah El Alaoui)

\section{SOLIDARIEDADE}

"Por ocasião da guerra das Malvinas, os Estados Unidos esqueceram a solidariedade devida a um país americano, prevista na Declaração da OEA, e apoiaram inequivocamente a agressão extracontinental de Margaret Thatcher." (Maurice Lemoine)

\section{IMAGENS FALSAMENTE VERDADEIRAS}

"O papel dos meios de comunicação num evento de proporções maiores quase sempre é questionado. Foi esse o caso das imagens de jovens palestinos comemorando os atentados em Nova York e Washington: até imagens reais podem 'mentir'."

\section{SOMOS A AMÉRICA, SAIA DA FRENTE!}

"Aperfeiçoaremos o sonho da energia nuclear. Depositaremos o lixo tóxico onde e quando decidirmos. Poderá apodrecer ao ar 
livre, em imensas planícies, durante milênios. Teremos os maiores e mais perversos mísseis e os apontaremos para onde quisermos." (Maureen Dowd)

\section{SHARON ENTRE O SONHO E A REALIDADE}

"Apoiando-se num presumível sinal verde da Casa Branca, alguns dos dirigentes de Israel chegam a sonhar em 'acabar o trabalho iniciado em 1948', ou seja, expulsar maciçamente a população palestina para os países vizinhos [...]” (Dominique Vidal)

\section{VOZES DISCORDANTES}

"'Sempre nos contentamos em denunciar os terroristas como bad boys, sem nos interessarmos em compreender os seus motivos', avalia, criticamente, James Schlesinger, ex-diretor da CIA e do Ministério da Defesa norte-americano." (Philip S. Golub)

\section{Arrependimentos}

"Zbigniew Brzezinski, principal assessor de Segurança do presidente James Carter, foi o homem-chave na ajuda maciça aos 'combatentes da liberdade' afegãos. Achou a idéia 'excelente', por atrair os russos para uma armadilha."

\section{O FUTURO DO PASSADO}

"Não podia dar certo. A Conferência, reunindo cerca de 3.000 ONGs, iria fazer ouvir num outro tom a voz dos povos oprimidos, manifestar sua solidariedade para com os palestinos e pesar sobre as decisões a serem encaminhadas." (Chistian de Brie)

\section{UMA GUINADA PARA O AUTORITARISMO}

"Quase todos os países da União Européia, depois dos choques de Göteborg, parecem caminhar para uma criminalização sistemática dos movimentos sociais, com a mesma posição que antes adotavam com relação aos imigrantes." (Salvatore Pallida) 


\section{As SACRIFICADAS DA LEVI STRAUSS}

"Dois anos e meio após o fechamento da única fábrica francesa da transnacional Levi Strauss, foi feita uma pesquisa para saber a atual situação das 541 operárias demitidas. A conclusão é edificante: ninguém sabe." (Emmanuel Defouloy)

\section{A guerra suja do Sur de Bolívar}

"Constituído em 1964, o ELN fez do Sur de Bolívar, há cerca de vinte anos, uma de suas trincheiras. Ano após ano, a guerrilha implanta a resistência nesse emaranhado de selvas e de montanhas, onde os militares negociam com os potentados da coca." (Maurice Lemoine)

\section{Riscos e PERIGOs NOS BÁlCÃs}

"Enquanto um certo nacionalismo macedônio exaltou o 'sonho estatal' - finalmente realizado com o fim da Iugoslávia -, os albaneses da Macedônia nunca consideraram a República independente, a não ser como um acidente temporário da história." (Jean-Arnault Dérens)

\section{Acordos E PLANOS DE PAZ}

"O negacionismo dos manga. A ofensiva revisionista nos quadrinhos inscreve-se num contexto mais geral. A direita japonesa sempre contestou a visão 'culpabilizante' do passado e rejeitou a idéia de agressão, negando as atrocidades cometidas pelo exército imperial." (Philippe Pons)

\section{A gUerra dA HistóRIA dA Ásia}

“A 'amnésia' japonesa é uma herança da Guerra Fria. O Japão foi empurrado para o lado dos 'bons' e o invasor norte-americano preocupou-se mais em reconstituir uma direita forte do que em pressionar o país a examinar o seu passado." (Philippe Pons) 


\section{A “RECEITA” DO MANGA REVISIONISTA}

"Irritado com tanta injustiça e tantas inverdades, o protagonista de Kobayashi investiga, relata, explode, se insurge e insulta o leitor, para lhe impor o seu ponto de vista ou bombardeá-lo com seus sarcasmos, dando à narrativa um tom provocador." (Philippe Pons)

"Os crimes do exército imperial." (Philippe Pons)

\section{BARENBOÏM E O TABU WAGNER}

"Há três meses, o maestro Daniel Barenboïm (israelense) executou (em Israel) um trecho da ópera Tristão e Isolda, de Wagner (músico-símbolo do nazismo), o que lhe valeu a execração pública. Um escritor (palestino) sai em defesa de Barenboïm e da arte." (Edward W. Said)

\section{Os CRIMes De GUERra DE Kissinger}

"Não há mais qualquer dúvida quanto à responsabilidade direta de Kissinger na prorrogação, injustificada, da guerra do Vietnã, nas operações de assassinato e subversão da democracia no Chile, ou quanto à sua cumplicidade no genocídio em Timor Leste." (Ibrahim Warde)

\section{PANORAMA DO MARXISMO}

"Do final da II Guerra Mundial até meados da década de 70, o marxismo prosperou, principalmente no sul da Europa e na América Latina, e, de maneira inesperada, foi para o universo anglo-saxão, deslocando-se de seu centro de gravidade." (Alain Bihr) 


\author{
SOBRE O LIVRO \\ Formato: $14 \times 21 \mathrm{~cm}$ \\ Mancha: 23,7 x 42,5 paicas \\ Tipologia: Horley Old Style 10,5/14 \\ 1a edição: 2009 \\ EQUIPE DE REALIZAÇÃO \\ Coordenação Geral \\ Marcos Keith Takahashi
}


CULTURA

ACADÊMICA \&

Editona 